ENCUESTA 



\section{ENCUESTA SOBRE LA RENOVACIÓN DEL TRIBUNAL CONSTITUCIONAL}

\section{PRESENTACIÓN}

Nuestros lectores más asiduos recordarán que el número 4 (segundo semestre de 1999) de esta revista tuvo carácter monográfico, dedicado al Tribunal Constitucional. Se cumplía entonces el vigésimo aniversario de la entrada en vigor de la Ley Orgánica del Tribunal Constitucional y la ocasión se presentaba propicia para una de nuestras instituciones constitucionales, según la expresión de García Pelayo. Posiblemente la más relevante de todas ellas.

En aquella época el supremo intérprete de la Constitución gozaba de una muy respetable cota de prestigio y de auctoritas. Para aquel trance optamos por una encuesta que partía de enfoques propios de la teoría constitucional, pero inmersa en el contexto en el que el alto tribunal desempeñaba sus funciones. El marco de la realidad abarcaba en aquel tiempo una reciente reforma de la LOTC con la incorporación de los denominados «conflictos en defensa de la autonomía local», un proyecto de reforma de ciertos aspectos del procedimiento en los conflictos de competencias y la previsión de una reforma que contuviese la avalancha de recursos de amparo, que entraría en vigor poco después.

Ahora, transcurridos doce años, el Tribunal Constitucional es — desde la letra del Titulo IX de nuestra Constitución - el mismo; pero su aureola se ha visto afectada por numerosas circunstancias exógenas: dificultades insuperadas por nuestras Cámaras partitocráticas para proponer en plazo al Rey candidatos a cubrir las vacantes; ha faltado entre nuestros políticos la «voluntad de Constitución» de que hablara Hesse. Subsiguientes situaciones de prorrogatio por periodos de largo tracto, huérfanos de precedentes en el constitucionalismo europeo occidental, donde el Tribunal Constitucional se ha considerado - y no sólo por Smend- como órgano renovador del consenso constituyente. A lo que se ha sumado alguna ley temeraria (el Estatut es el mejor ejemplo) que ha situado al Tribunal al borde del abismo, con subsiguientes presiones políticas sobre los Magistrados — si hemos da dar crédito a los medios de comunicación- que demostrarían cuanta razón asistía a Kelsen al exteriorizar su temor a intromisiones de los partidos en el funcionamiento independiente del Tribunal. Presiones que sirven para procurar desprestigiar a quienes las despliegan. A lo anterior cabría quizás sumar el desempeño de la Presidencia y de la Vicepresidencia del Tribunal por quienes no son Catedráticos de Derecho, dato también anómalo en el horizonte del constitucionalismo comparado. Y todo un conjunto de circunstancias — bien diferentes a las que rodearon a nuestro primer Tribunal 
Constitucional - que poco parecen poder aportar al prestigio de tan señera institución.

Teoría y Realidad Constitucional hoy, como siempre, procura desplegar su tarea científica desde el máximo respeto hacia nuestro sistema constitucional, pero es consciente de que el Tribunal Constitucional no vive en una campana de cristal que genere un micro clima inerte y estéril. No es un Instituto jurídico sito en un recipiente «al vacío». Es un tribunal cuyos miembros naturalmente son humanos y cuyos nombramientos no provienen de un singular agujero negro de una lejana galaxia. Muy al contrario es fruto y reflejo de la problemática de la faceta publica de nuestra sociedad y su situación de presente pensamos modestamente que se debe analizar por los constitucionalistas desde el debido realismo. Nos ha parecido obvio que sobre materias tan complejas y delicadas no puede aspirarse a un pronunciamiento dogmático. Mayor interés tiene a nuestro juicio recoger opiniones de prestigiosos colegas, siempre complementarias y, en ocasiones, diferentes e incluso divergentes.

Esperamos que el dialogo tácito, que mantienen con la mayor libertad los encuestados, engendre luz para facilitarnos a todos una visión clara de problemas a los que nadie querrá aplicar la política de la avestruz, sino un certero diagnóstico y la mejor terapia jurídico constitucional.

\section{CUESTIONES}

1. Al calor del dilatado proceso en que el TC delibera y dicta la Sentencia sobre el Estatuto de Cataluña ha habido comentarios en medios de comunicación cuestionando el prestigio e incluso la legitimidad del alto Tribunal, una vez que en su seno se habian producido recusaciones, vacante por fallecimiento, un significativo número de magistrados en situación de "prorrogatio», dado que la Cámara correspondiente no proponía al Rey el nombre de los sustitutos y el que a casi todos los magistrados se les encasillaba en una ideología y/o disciplina progresista o conservadora. ¿Nos puede decir Vd. si cree que el supremo intérprete de la Constitución ha sufrido algún desgaste en su prestigio inicial y, en caso afirmativo, especialmente por qué causas y aportarnos una valoración global?

2. Transcurridos más de treinta años de vigencia de nuestra Constitución, ¿la composición que para el TC prevé el art. 159 le parece óptima o sugeriría alguna propuesta de constitutione ferenda? Y en la medida en que está en vigor el apartado 2 de tal precepto ¿entiende que el requisito de la reconocida competencia de todos los magistrados se limita a que cuenten con más de quince años de ejercicio profesional o debe conllevar un plus?

3. ¿Nos quiere formular algún comentario acerca de la LO 6/2007, de 24 de mayo, que reforma varios preceptos de la LOTC y, más específicamente, sobre su incorporación de la presentación de candidatos a ser magistrados por las Asambleas Legislativas de las CCAA al Senado?

4. ¿Nos podría dar su opinión respecto a la reforma del apartado 3 del art. 16 LOTC en lo que respecta a la "prorrogatio» del presidente y del vicepresidente?

5. Y lo preceptuado en el apartado 3 del propio art. 159 CE sobre que los miembros del Tribunal «serán designados por un período de nueve años y se renovarán por terceras partes cada tres» ¿Qué fuerza de obligar debería tener para los correspondientes poderes constituidos a los que está encomendada la propuesta al Rey de los nuevos miembros del Tribunal? En conexión con lo anterior 
¿Cree Vd. que la ratio del art. 17 LOTC está siendo bien desplegada por quienes tienen que aplicarlo? ¿Propondría Vd. la modificación del precepto o sólo la de sus prácticas aplicativas? Más en concreto, ¿Qué sugerencias haría Vd. sobre cómo deberían comportarse los grupos parlamentarios al asumir sus responsabilidades al respecto?

6. A su juicio ies inconstitucional que se acumulen en un mismo momento las propuestas de nombramientos de más de un tercio — por ejemplo, dos tercios - de los miembros del Tribunal Constitucional? ¿Y podría Vd. hacernos algunas consideraciones sobre la reforma de la LOTC, mediante LO 8/2010, de 4 de noviembre?

7. ¿Sugeriría algunos modelos, de entre los que ofrece el Derecho constitucional comparado occidental, para inspirar en España una revisión de la forma de abordar la cobertura de vacantes o la sustitución de los magistrados que tienen agotado el término de su mandato?

\section{ENCUESTADOS}

Luis Aguiar De LuQue. Catedrático de Derecho Constitucional de la Universidad Carlos III de Madrid

Francisco Javier Díez Revorio. Catedrático de Derecho Constitucional de la Universidad de Castilla y La Mancha

Alfonso Fernández Miranda. Catedrático de Derecho Constitucional de la Universidad Complutense de Madrid

José Vicente Gimeno Sendra. Catedrático de Derecho Procesal de la UNED

Manuel Jiménez de Parga. Catedrático de Derecho Constitucional de la Universidad Complutense de Madrid

Javier Pérez Royo. Catedrático de Derecho Constitucional de la Universidad de Sevilla

Ramón Punset Blanco. Catedrático de Derecho Constitucional de la Universidad de Oviedo

Juan Alfonso Santamaría Pastor. Catedrático de Derecho Administrativo de la Universidad Complutense de Madrid

UNED. Teoría y Realidad Constitucional, núm. 28, 2010, pp. 13-90. 


\section{RESPUESTAS}

1. Al calor del dilatado proceso en que el TC delibera y dicta la Sentencia sobre el Estatuto de Cataluña ha babido comentarios en medios de comunicación cuestionando el prestigio e incluso la legitimidad del alto Tribunal, una vez que en su seno se habian producido recusaciones, vacante por fallecimiento, un significativo número de magistrados en situación de "prorrogatio», dado que la Cámara correspondiente no proponía al Rey el nombre de los sustitutos y el que a casi todos los magistrados se les encasillaba en una ideología y/o disciplina progresista o conservadora. ¿Nos puede decir Vd. si cree que el supremo intérprete de la Constitución ha sufrido algún desgaste en su prestigio inicial y, en caso afirmativo, especialmente por qué causas y aportarnos una valoración global?

\section{Luis Aguiar De LuQue}

La pérdida de prestigio del Tribunal Constitucional en el largo proceso de deliberación y resolución de la sentencia sobre la reforma del Estatuto de Autonomía de Cataluña me parece incuestionable. Más aún, la importante merma de credibilidad del órgano de jurisdicción constitucional (que en los años 80 y 90 contribuyó de manera decisiva a la clarificación de algunos de los aspectos más relevantes del estado autonómico) quizás sea una de las consecuencias más gravosas para el futuro de nuestro régimen constitucional que ha acarreado el proceso de reformas estatutarias llevado a cabo en la VIII Legislatura.

Las causas de esa pérdida de prestigio son evidentemente muy variadas. No obstante con carácter previo y a fin de contextualizar adecuadamente el tema quizás convenga recordar que con anterioridad a dicho proceso a fines de los 90 se manifestaron ya ciertos elementos tanto en los debates en el seno del Tribunal, como en el tono de la crítica que determinados medios de comunicación o algunos sectores políticos realizaban a concretos pronunciamientos del Tribunal, que parecían augurar que algo estaba cambiando en nuestro sistema político-institucional en cuanto al modo de entender el papel y significado de la jurisdicción constitucional en nuestro régimen. Baste recordar el tono del debate en el seno del Tribunal que parecen reflejar las sentencias (y más aun los votos particulares), así como algunos de los comentarios periodísticos y reacciones de las diferentes fuerzas políticas respecto a los pronunciamientos del Tribunal en los casos «Mesa Nacional de HB» (STC 136/99 de 20 de julio) y «Reforma de la LOPJ» (STC 105/2000 de 13 de abril).

Instalado ese clima «en el seno de» y «en el entorno político a» el Tribunal Constitucional el debate sobre la reforma del »Estatut» en sede constitucional, ciertamente constituyó un importante salto en el modo de entender el papel que la jurisdicción constitucional debía desempeñar en nuestro sistema institucional, pero creo que también debe ser en cierta medida valorado como el colofón de una deriva que se había iniciado a fines de los 90, deriva que no es ajena a los nuevos modos de desenvolverse las relaciones entre los principales partidos del arco parlamentario; en suma, el modo de configurarse el sistema político institucional en su conjunto. Como no podía ser de otro modo el Tribunal Constitucional, aunque instancia autónoma, dotada de una lógica y una dinámica autónomas y propias respecto a aquellas otras instituciones de naturaleza estrictamente polí-

UNED. Teoría y Realidad Constitucional, núm. 28, 2010, pp. 13-90. 
tica, no permanece ajeno a los vaivenes que en su entorno se producen, vaivenes que repercuten en el modo de desarrollarse los procesos de renovación, el tipo de problemas que se encomiendan al mismo, la forma de implementar las decisiones que éste adopta o el papel que se pretende que asuma esta institución... O dicho de otro modo, la configuración del sistema político incide irremediablemente en el desenvolvimiento de las funciones del Tribunal y algo de eso comenzó a producirse en los últimos años de la década de los 90 .

Ahora bien, como he apuntado más atrás, el proceso sobre el «Estatut» también supone un importante salto cualitativo en esa evolución. Y desde esa perspectiva, el elemento —en mi opinión- más significativo (y a la postre definitivo a los efectos de lo aquí interesado) es la escasa prudencia de la que hicieron gala las dos principales fuerzas políticas a nivel estatal trasladando al Tribunal Constitucional (sea por acción o sea por no haber adoptado las medidas adecuadas para que dicha acción se produjese) un debate y unos desacuerdos tan intensa e inmediatamente políticos como son la definición de los aspectos esenciales de la organización territorial del Estado que desbordan las capacidades reales de la jurisdicción constitucional en el marco del sistema democrático-constitucional a la par que desgasta irremediablemente a la institución que la padece.

Con ello no pretendo negar la posibilidad de que los Estatutos de Autonomía sean objeto de un recurso de inconstitucionalidad. Como leyes orgánicas que son, los Estatutos de Autonomía se hallan evidentemente subordinados a la Constitución y pueden en el terreno formal ser objeto de control de constitucionalidad. Pero un parámetro para medir una determinada acción es el que viene definido por las exigencias juridíco-formales para promover un determinado recurso de inconstitucionalidad y otro distinto el que impone a las grandes fuerzas políticas actuar con responsabilidad institucional para no desnaturalizar las principales instituciones del régimen constitucional.

En la presente ocasión, por la significativa profundización del autogobierno que la reforma estatutaria representaba (aunque quizás fuera más correcto hablar de reformas estatutarias porque, como es bien sabido, el Estatuto andaluz sigue de cerca al Estatuto catalán), por la extensión de las divergencias que las principales fuerzas parlamentarias de ámbito nacional tenían sobre esta cuestión, por la importante fractura en la ciudadanía que dicho tema provocaba y por la irremediable dimensión político-ideológica que dicha cuestión encierra, lo que se ventilaba en dicho proceso constitucional no era sólo (aunque también) la adecuación o no a la Constitución de unos concretos preceptos legales recogidos en un Estatuto de Autonomía. Era mucho más. Lo que en verdad latía en aquel proceso y se demandaba del Tribunal era que sentara las nuevas líneas maestras que habían de inspirar un nuevo entendimiento del Estado de las Autonomías, líneas que no se sitúan ni dentro ni fuera de la Constitución, sino más allá de la misma, de sus contenidos explícitos y de las previsiones implícitas del constituyente.

El Tribunal, se comparta o se discrepe con la argumentación técnica de la sentencia, se vio así impelido a desempeñar un papel cuasiconstituyente que en verdad debía haber sido resuelto por las principales fuerzas políticas en sede parlamentaria y se encontró embarcado en un proceso constitucional del que difícilmente podía salir indemne. 
Para confirmar lo que acabo de señalar me limitaré a recuperar un interrogante que en varias ocasiones me planteé en los últimos meses del debate constitucional sobre el «Estatut»: ¿Es posible imaginar algún tipo de sentencia que no hubiera provocado un amplísimo rechazo en un amplio sector de la clase política, de los medios de comunicación o del colectivo de juristas? La respuesta que me dí entonces y que reitero ahora fue siempre la misma: puede que la excesiva demora en resolver el proceso no haya favorecido la imagen del Tribunal en la opinión pública, pero situado en la tesitura en la que se le había colocado a este órgano por las fuerzas políticas, el rechazo al pronunciamiento del tribunal iba a ser tan amplio e intenso en muchos sectores que la pérdida de prestigio y credibilidad era irremediable

\section{Francisco Javier DíEz Revorio}

En efecto, parece que el Tribunal Constitucional viene sufriendo un acusado desgaste y su imagen como institución se ha ido deteriorando en los últimos años. El proceso de emanación de la sentencia sobre el Estatuto de Cataluña, al que alude la pregunta y luego me referiré, ha tenido que ver desde mi punto de vista con este desprestigio del Tribunal, pero no es la única causa del mismo. En efecto, con posterioridad a dicha sentencia, y a pesar de que la superación de ese proceso y la posterior renovación parcial del Tribunal parecían inaugurar un nuevo escenario, los acontecimientos han seguido incidiendo en el desprestigio del Tribunal. El consenso para renovar a otro tercio de magistrados (el que corresponde proponer al Congreso) no fue finalmente alcanzado, hasta el punto de haber llegado, mediando por cierto la muy polémica sentencia en el llamado caso Bildu, a la dimisión de los tres magistrados que están en situación de prorrogatio, que no ha sido aceptada por el presidente del Tribunal; y a que el presidente del Congreso haya tenido que dar un plazo a los grupos que componen la Cámara para que eleven su propuesta. Plazo que en el momento de escribir estas líneas ha vencido sin acuerdo, ni visos de que éste se alcance próximamente.

Por tanto, si bien es claro que la sentencia sobre el Estatuto ha situado al Tribunal en una situación excepcional que ha provocado en el mismo una crisis sin precedentes, me temo que el supremo intérprete de la Constitución está aún lejos de superarla, un año después de la adopción de la polémica sentencia. En mi opinión, reconocer esta crisis, que afecta sobre todo a la imagen social y política del Tribunal, es compatible con afirmar que todas las decisiones que el Tribunal ha adoptado son perfectamente legítimas, en cuanto que han seguido las prescripciones previstas en la Constitución y en la ley, resolviéndose los posibles conflictos y dudas por los órganos competentes (llegado el caso, el propio Tribunal Constitucional) a través de los procedimientos establecidos. Es decir, el Tribunal ha sufrido un importante desgaste y descrédito en su imagen, pero sería injusto, inadecuado y altamente lesivo para nuestro sistema democrático y de garantías constitucionales hablar de carencia de legitimidad en el mismo o en sus decisiones.

Ahora bien, dicho esto, resulta indudable que en el curso del proceso que condujo a la emanación de la sentencia sobre el Estatut se produjeron diversas situaciones que carecían de precedentes en la historia del Tribunal: sucesión de recusaciones «cruzadas» de distintos magistrados (de las cuales una fue aceptada con argumentos más que dudosos); 
situación de prorrogatio de varios magistrados que, si bien no carecía de precedentes, superó con creces todos ellos hasta el punto de llegar a acumularse, poco después de la sentencia, la necesidad de renovar dos tercios de los magistrados; previsibilidad (real o supuesta, pero reiteradamente proclamada en muchos medios) de la postura de la mayoría de los magistrados, hasta el punto de formarse dos bloques respecto a la valoración del Estatuto, cuyo equilibrio se trataba de romper por las partes en el proceso con dichas recusaciones, o no renovando tampoco la plaza vacante por el fallecimiento de un magistrado; declaraciones públicas de distintos responsables políticos y medios de comunicación sobre la propia constitucionalidad del Estatuto, cuya finalidad de presionar al Tribunal resultaba notoria (y entre ellas cabe destacar la insistencia del presidente del Gobierno en diagnosticar y pronosticar la constitucionalidad del Estatuto)... Estos y otros factores provocaron que dicho proceso haya constituido una de las etapas más delicadas y negativas de la historia del Tribunal. Hasta tal punto es así que, en mi opinión, llegado cierto momento cualquier sentencia era mejor que el impass en el que había entrado la institución.

Y desde luego, la sentencia 31/2010, a pesar de la polémica que ha generado, parecía cerrar una etapa crítica en el Tribunal. Con independencia de las críticas que pueda merecer, la decisión resolvió la controversia planteada por las vías previstas, y debía haberse hecho acreedora del máximo respeto. Las reacciones políticas a la misma no contribuyeron, sin embargo, a calmar la situación. Es muy curioso que tanto el partido al que pertenecían los recurrentes, como el Gobierno de España, considerasen públicamente que la sentencia apoyaba globalmente sus tesis: la de la inconstitucionalidad significativa del Estatuto para los recurrentes, y la de la conformidad global con la Constitución e irrelevancia de las inconstitucionalidades para el Gobierno estatal. Pero si las «correcciones» hechas por el Tribunal al Estatut hubieran sido en verdad tan poco significativas, no se entendería muy bien el airado rechazo a la sentencia desde el mismo Gobierno catalán y buena parte de los partidos de Cataluña, así como las multitudinarias manifestaciones en su contra. Desde luego, las críticas a esta sentencia, como a cualquier otra, son legítimas desde las perspectivas política y jurídica, siempre que vayan acompañadas del acatamiento y la lealtad institucional imprescindibles en el cumplimento y ejecución de la misma. Y estas actitudes (que por otro lado sí resultan perfectamente compatibles con la búsqueda de diversas alternativas, tanto de cambio normativo como de aplicación jurídica ante el nuevo escenario abierto por la sentencia) no siempre han estado presentes en los agentes implicados en el cumplimiento y ejecución de la sentencia.

En cualquier caso, y como antes he sugerido, la sentencia sobre el Estatuto catalán no ha logrado cerrar la crisis abierta en el Tribunal no tanto (y no sólo) por las reacciones contrarias y las dificultades de aplicación que la misma ha encontrado, sino por la persistencia de ciertos factores más de fondo que están en la causa de esa crisis, como la no renovación de parte de los magistrados, y la falta de respeto al Tribunal desde instancias políticas.

En mi opinión, y como valoración global de la situación que vive actualmente el Tribunal, encontramos algunos factores que son comunes a todo Tribunal Constitucional y que en alguna medida siempre han estado presentes en el nuestro (y no resultan por tanto tan preocupantes, pues pueden casi considerarse «inherentes» a la labor del Tribunal), junto a otros que han aparecido (o se han intensificado hasta límites inaceptables) 
en los últimos años, y que mientras no sean superados impedirán al Tribunal salir de esta grave crisis.

Entre los primeros está la naturaleza política y la gran trascendencia social de muchos conflictos a los que ha de hacer frente el Tribunal, y el consiguiente posicionamiento de diversos sujetos políticos ante sus sentencias. Bachof afirmaba que corresponde al Tribunal Constitucional la solución jurídica de conflictos políticos, y por tanto es esta una característica sustancial de su actividad, que muchas veces vendrá acompañada de la polémica por sus sentencias. En el caso español, basta recordar las sentencias en los asuntos LOAPA, ley de despenalización del aborto, RUMASA, GRAPO, Batasuna, Ley del Suelo, entre tantos otros ejemplos, para comprender que la polémica por sus decisiones no era una característica ni mucho menos insólita en nuestro Tribunal Constitucional de los años 80 y 90 .

Sin embargo, más recientemente se viene produciendo una circunstancia negativa y novedosa (o al menos relativamente novedosa, pues nunca antes se había producido con tal intensidad) como es la división de los magistrados en «bloques» que parecen actuar de manera estable y buena parte de la sociedad —y desde luego de los medios de comunicación- identifica con mayor o menor razón como «magistrados conservadores» y «magistrados progresistas». Es claro que, desde el punto de vista cuantitativo, la mayor parte de las resoluciones del Tribunal son aprobadas de forma unánime o sin que se produzca esa división en bloques. Pero el hecho de que, con algunas excepciones dignas de destacar, tales bloques hayan funcionado realmente de ese modo en algunas de las sentencias más polémicas y con mayor trascendencia política de los últimos años, ha contribuido desde mi punto de vista a dañar significativamente la imagen social del Tribunal. Conociendo la tendencia ideológica o política (sea esta más o menos real) de los distintos magistrados, se puede prever y pronosticar su decisión en determinados asuntos de gran trascendencia. Y lo cierto es que, por más rechazables que sean las especulaciones mediáticas en este sentido, tienden a «acertar» en sus pronósticos. Se produce así una perniciosa previsibilidad que nada tiene que ver con la idea de seguridad jurídica, sino que es casi su antítesis, porque no se trata de que gracias a la certeza del Derecho se pueda prever la respuesta jurídica a un asunto determinado, sino de que, conociendo la tendencia de los distintos magistrados y el peso específico de los distintos «bloques», se puede pronosticar sin demasiado margen de error cuál será su decisión en un asunto determinado de trascendencia política. Y eso con independencia de lo que diga la Constitución o de lo que haya dicho antes el propio Tribunal. De este modo, ante esta situación los partidos y las instituciones pueden verse tentados a intentar alterar la decisión si no interesa, con presiones o subterfugios variados; o, a la inversa, prolongar más allá de los dictados legales una composición que se presume favorable. Naturalmente esto implica que algunos agentes políticos utilizan el Tribunal como un escenario más de batalla para conseguir sus objetivos o intereses, como una parte del gran tablero de la política a la que no importa dañar si se piensa que de ese modo se logra una decisión favorable a un posicionamiento político o de cualquier modo se logra un propósito político determinado.

En suma, probablemente lo que diferencia al Tribunal de los últimos años del existente en las primeras décadas de funcionamiento no es tanto la enorme polémica política que acompaña a algunas decisiones (eso se ha producido siempre), sino una cierta 
pérdida del respeto que debe merecer esta institución, de la que son culpables tanto los partidos políticos como algunos representantes institucionales y, en alguna medida el propio Tribunal, que por diversas razones no siempre alcanza a mostrar la auctoritas imprescindible para el correcto funcionamiento institucional.

A ello cabe añadir que, probablemente, desde el punto de vista social y político en los primeros años se percibía más claramente la enorme y trascendental labor de interpretación y desarrollo de los preceptos constitucionales que el Tribunal llevaba a cabo, sobre todo en materia de derechos fundamentales. Esa labor, que resultó imprescindible para transformar «en favor de los principios constitucionales» la práctica judicial, así como la actuación de las instituciones, los ciudadanos y los sujetos políticos, adecuándolas a la norma fundamental, acaso no se perciba hoy como tan necesaria, lo que puede empezar a generar la idea de que el Tribunal resultaría ya una institución prescindible.

\section{Alfonso Fernández Miranda}

Me acojo a la generosa libertad que la revista nos concede para reestructurar, en parte, no tanto las preguntas, todas muy pertinentes y muy atinadas, como el orden de las respuestas. Responderé con cierta extensión a la primera pregunta que es la que aborda el problema esencial del cuestionamiento creciente de la legitimación y de la misma legitimidad de nuestro Tribunal Constitucional (TC). Pero al indagar sobre las causas de este proceso de deslegitimación será inevitable referirse a los problemas que se plantean en las preguntas ulteriores, de suerte que al abordar éstas, en ocasiones se procederá a un desarrollo de lo ya apuntado en la primera respuesta y, en otras, a una remisión. Entiendo que es la forma más sistemática y ordenada de dar respuesta a la Encuesta. A ello añado que, también por razones sistemáticas que explicaré, voy a dar respuesta conjunta a la preguntas tercera, cuarta, quinta y sexta.

Siempre he tenido muy en cuenta en mis escritos y exposiciones sobre Derecho Constitucional, la sabia reflexión de Jürgen Häbermas para quien «el constitucionalista ha de ver siempre en las normas y junto a ellas el enunciado permanente de la tarea práctica que es la legitimación del orden político». Por ello, cuando me aproximo con una actitud sumamente crítica al funcionamiento de una institución de la importancia que para el sistema tiene el TC, siempre me asalta la duda de cuál es el límite; dónde termina la crítica necesaria para la regeneración institucional y dónde empieza una personal contribución a la deslegitimación del sistema. Evidentemente a una institución de la envergadura funcional del TC ningún jurista responsable puede aproximarse cargado de prejuicios y mucho menos con frivolidad. Pero hemos llegado a un punto en el que la peor de las actitudes es el silencio y la mayor irresponsabilidad la ceguera o el ocultamiento de una realidad evidente: El caudal de enorme prestigio acumulado por el Tribunal en sus primeros años de funcionamiento ha ido degradándose hasta límites inquietantes. Hoy el Tribunal es objeto de durísimas críticas provenientes tanto de la opinión pública como de la comunidad jurídica.

Pidiendo disculpas por la extensa auto-cita, en el año 2008, respondiendo a otra Encuesta en el número 21 de esta revista, abordaba el mismo problema a partir de la dis- 
tinción entre legitimidad — cuyo cuestionamiento era aún muy minoritario entre nosotros - y legitimación - cuando ya asistíamos a un proceso creciente de deslegitimación.

"Cuando bablo de legitimación —escribía entonces - obviamente, no hablo de legitimidad. Ésta la tiene el Tribunal en virtud de las competencias que la Constitución le atribuye y en la medida en que aplique la propia Constitución desde criterios jurídicos de objetividad eludiendo los criterios políticos de oportunidad. Se trata de un concepto normativo que determina la pacificación jurídica de los conflictos pero que no determina su pacificación política. Por el contrario, el de legitimación es un concepto sociológico, imprescindible para la pacificación política, que dice de la aceptación social del sentido y del contenido de las sentencias.

Quizás haya que reconocer que en los últimos tiempos la legitimación del Tribunal está sufriendo más de lo deseable. No quiero ignorar que algunas actuaciones internas - concretamente en los casos de recusaciones en cuyo análisis, desde luego, no voy a entrar abora - no han transmitido una gran delicadeza ni han resultado ejemplares ni en su tramitación ni en su resolución. Pero entiendo que las causas auténticamente relevantes de esa relativa y parcial disminución del gran prestigio del que la institución ba venido gozando, son fundamentalmente causas externas. La primera, que en gran parte arrastra a las demás, el que hayan ido llegando al Tribunal conflictos que aunque puedan enmarcarse y resolverse jurídicamente, son esencialmente politicos, y debieron resolverse políticamente sin trasladarlos al Tribunal en las condiciones en que se ha becho. Desde el conflicto sobre la admisión a trámite de la propuesta de reforma del Estatuto Vasco, hasta el recurso contra el Estatuto de Cataluña, bay un conjunto de actuaciones en las que los partidos han transferido la lucha política, con escasa responsabilidad, a sede judicial. Simbolizando esta situación en el caso del Estatuto de Cataluña (respecto al que la sentencia que imponga la paz jurídica desatará con toda certeza un terremoto político, cualquiera que sea el sentido del fallo) lo que se ha hecho llegar al Tribunal es una norma básica del «bloque de constitucionalidad» que por primera vez no se ba consensuado, que divide radicalmente a las fuerzas políticas, que divide a la sociedad española y que, como última carga de profundidad, llega al Constitucional tras un referéndum en el que los ciudadanos de Cataluña aunque con una participación más bien ridícula - han dado a la norma su aprobación.

Tras la entrada del recurso en el Tribunal se sucederán una serie de episodios lamentables que expresan la voluntad política de condicionar desde fuera el sentido del fallo manipulando la composición del Órgano: Los episodios de las recusaciones, la Ley Orgánica de reforma del Tribunal que prorroga el mandato de Presidenta y vicepresidente (que me parece perfectamente constitucional pero que estoy absolutamente seguro se hubiera producido igualmente siguiendo la tradición sin necesidad de esa discutible intervención externa) y que modifica, en un claro anticipo de la ejecución del Estatuto de Cataluña, el procedimiento de selección de Magistrados por el Senado, con una intervención legislativa cuya constitucionalidad no se me antoja evidente por cuanto desapodera parcialmente al Senado de una competencia atribuida sin condiciones por la Constitución, supone una ingerencia en la autonomía de la Cámara para organizar el ejercicio de competencias propias y descansa en un razonamiento seriamente discutible: acomodar la composición del Tribunal y el modelo de selección al Estado de las Autonomías. Esta forma de razonar que consiste en preconstituir dogmáticamente la institución y luego proyectarla a partir de la naturaleza fabricada, no es propia de un jurista. Acaso se deba reformar el Senado en sentido federal, pero la Constitución, hasta el día de boy, ni quiso diseñar ni ha diseñado una Cámara federal, sino una Cámara fundamentalmente de segunda lectura con representación de base territorial mixta: provincial y autonómica. El resultado de esta reforma ha sido un nuevo recurso, de resolución necesariamente prioritaria, y nuevos retrasos tanto en la sentencia sobre el Estatuto de Cataluña como en la propia renovación del Tribunal.

UNED. Teoría y Realidad Constitucional, núm. 28, 2010, pp. 13-90. 
Mención expresa merece, en este proceso de deslegitimación, el comportamiento de algunos medios de comunicación. Han querido transmitir a la opinión pública la idea de un Tribunal radicalmente escindido en "conservadores» $y$ "progresistas», esclavos no solo de sus prejuicios sino de sus dependencias políticas, perfectamente previsibles, pero no en función de la previsibilidad del derecho sino de sus alineamientos políticos con los partidos que los promovieron al cargo. En definitiva, de forma más o menos meliflua se les ha negado la independencia a la totalidad de los magistrados. Sus votos serán a favor del Gobierno o contra el Gobierno.

Estos alineamientos, irresponsablemente fomentados, no son ciertos, pero corren el riesgo de acabar convirtiéndose en la profecía autocumplida. El Tribunal Constitucional ni ha sido ni es el Consejo General del Poder Judicial, sobre todo porque los lazos de vinculación política son mucho más difíciles de resistir en una función gubernativa que en una función jurisdiccional. El bábito hace al monje».

En el transcurso de tres años el proceso de deslegitimación del Tribunal no ha dejado de crecer pero, además — sobre todo a raíz del recurso de inconstitucionalidad contra la Ley Orgánica que aprobó el nuevo Estatuto de Cataluña— se han abierto paso voces crecientes que ya no apuntan sólo ni sobre todo a la falta de legitimación sino directamente a la falta de legitimidad democrática de éste o de cualquier Tribunal para enjuiciar y anular o inaplicar cualquier Ley fruto de la voluntad de un Parlamento democrático o, con mayor moderación, algún tipo específico de leyes como las Orgánicas que aprueban los Estatutos de Autonomía o/y las que han sido objeto de refrendo popular. Se trata, pues, de la eterna resurrección de la vieja polémica entre principio democrático y justicia constitucional que acaso tuvo su primera formulación concreta (no en el plano teórico, sino en la reacción práctica ante una concreta decisión del Tribunal Supremo USA) cuando Jefferson afirmó, tras la sentencia del caso Marbury v. Madison, que «Considerar a los jueces como los árbitros finales de todas las cuestiones constitucionales, es una doctrina muy peligrosa, que nos colocaría bajo el despotismo...»

Abordaré estos problemas planteando primero, de manera muy sucinta, las críticas a la legitimidad y después las relativas a un funcionamiento deslegitimador. Ni que decir tiene que no se trata de compartimentos estancos, que una fuerte legitimación suministra argumentos contundentes al principio de legitimidad y que, a la inversa, una fuerte deslegitimación abona la idea de que los sacrificios que pudiera comportar la atribución a un tribunal de tan formidable competencia, no están en absoluto justificados por los beneficios de la institución.

\section{A) Problemas de legitimidad}

Voy a dividir este epígrafe en dos subepígrafes. El primero referido a la gran cuestión teórica de la legitimidad de la justicia constitucional en general, y el segundo a determinadas posiciones, extendidas en España, que sin negar esa legitimidad de forma radical, la niegan para el control de determinado tipo de leyes.

I. La historia de la polémica que pretende enfrentar a la justicia constitucional (singularmente al control de las leyes) con el principio democrático, enfrentar, al cabo, democracia y Estado Constitucional de Derecho, es tan vieja como lo es el propio movimiento constitucional que emerge con fuerza en el último tercio del siglo XVIII. Este conflicto que se hace visible de forma recurrente a lo largo de la historia, que formula una 
permanente tensión entre democracia y justicia, entre voluntad y razón, y que tiene una de sus manifestaciones más extremas en el reproche «del gobierno de los jueces», es imposible de abordar en los márgenes que permite una modesta respuesta a las preguntas de una encuesta. Se trata, nada menos, que de uno de los grandes problemas de la teoría de la Constitución y de la teoría de la Democracia que se merece un extenso y riguroso análisis y no un fusilamiento sumario. Por ello voy a limitarme a unas pinceladas de brocha gorda y a mi toma de postura personal.

Empezando por la brocha gorda, desde el enfrentamiento teórico y político entre Hamilton y Jefferson o desde la derrota de las pretensiones de Sieyés y Condorcet frente al jacobinismo intransigente que identifica al Parlamento con la encarnación de la soberanía nacional, la polémica ha estado doctrinalmente muy bien servida. De un lado, aunque sin duda con matices (y todo ello sin el menor ánimo exhaustivo — seguimos en la inevitable brocha gorda-) Kelsen, Dworkin o Häbermas; del otro, desde Jefferson, importantes autores norteamericanos como Jeremy Waldrom o Ely (aunque la posición de Ely, desde su defensa de la democracia»procedimental» me merecerá una especial atención más adelante) hasta posiciones como la de los defensores del «constitucionalismo débil» que más que oponerse a la justicia constitucional la someten a severas restricciones, o la del neoconstitucionalismo (hijo de la izquierda italiana, de las posiciones españolas antisistema y de los nuevos movimientos revolucionarios latinoamericanos) que en realidad no se oponen al control judicial sino que, en una nueva y tosca versión del «uso alternativo del derecho», se oponen cuando la institución limita la acción «revolucionaria»del Gobierno, y lo apoyan cuando lo configuran como un instrumento más al servicio de la «revolución». Se trata de una posición irrelevante cuando nos movemos en el ámbito de la democracia constitucional y de la constitución normativa.

Concluyendo con mi personal posición, hay una pregunta sobre la democracia que estimo de la máxima relevancia: ¿El poder democrático es un poder jurídicamente limitado y políticamente responsable o, por el contrario, se trata de un poder ilimitado e irresponsable? La respuesta a esta pregunta requiere, según creo, formular otra previa y fundante: ¿Cual es el fundamento legitimador de la democracia? ¿Por qué es legítima la decisión política y por qué es válido el derecho en que se concreta? ¿Por qué debe ser lo que la norma dice que debe ser? Estas preguntas tienen, en teórica democracia, dos respuestas posibles.

La primera, que reconduce a la democracia directa y que no tiene objeción alguna a que el poder político sea directamente ejercido, sin intermediarios, por el soberano, sitúa la regla de la mayoría como principio legitimador del sistema: La decisión política y el mandato jurídico son legítimos y válidos porque así lo quieren los más. La mera regla de resolución de conflictos y de reducción de la complejidad se convierte, nada menos, que en principio de legitimidad del sistema político. La dificultad de este planteamiento reside, a mi juicio, en la nula significación ética y política del neutro dato matemático de ser más y abre la siguiente pregunta ¿por qué hay que obedecer a lo que digan los más? ¿Acaso su juicio es más certero, conveniente, oportuno o justo que cualquier otro? ¿En qué se diferencia la dictadura de la mayoría de la dictadura del más fuerte? (aunque la historia enseña que toda dictadura que nace con el apoyo de la mayoría acaba siendo la dictadura del más fuerte). Pero sobre todo, este planteamiento ofrece un flanco de debilidad que se me antoja insalvable. Sabemos, desde la lógica trascendental kantiana, que 
el universo del ser y el del deber ser no son transitables sin más, que las cosas no son porque deban ser ni deben ser porque sean, que, en suma, carece del menor sentido fundar una obligación moral sobre un mero hecho matemático.

Si lo que se pretende es un poder «democrático» omnímodo, irresponsable y jurídicamente ilimitado, no hay cuestión: La justicia constitucional es insostenible por manifiestamente antidemocrática.

Si, por el contrario, se sitúa como fundamento de legitimidad un valor — por ejemplo la libertad de todos, la igualdad en la libertad- lo decisivo es que el poder democrático, cualquier poder, asegure y garantice la libertad de todos, la libre formación de las mayorías y su reversibilidad potencial. Entonces, si lo que garantiza la legitimidad de la decisión de la mayoría, no es el irrelevante hecho matemático de ser más, sino el dato valioso de ser una mayoría libremente formada, si lo que dota de dignidad a la regla de la mayoría (ya no principio sino mera regla de toma de decisiones) es que es una mayoría libremente formada que decide tras un proceso abierto de libre participación, entonces el poder democrático, con necesidad lógica, es un poder políticamente responsable y jurídicamente limitado por la necesidad de garantizar los derechos fundamentales, el ámbito de igualdad en la libertad que garantiza la existencia de una sociedad políticamente abierta y libre. No hay democracia sin Constitución.

Desde esta última posición me he permitido hace tiempo definir la Constitución como la norma que organiza las formas del poder al servicio de los derechos, historicamente percibidos como necesarios, para establecer y mantener una sociedad políticamente libre y abierta.

Si se acepta esta fundamentación del poder democrático, se aceptará la radical sumisión de la mayoría a la garantía de la libertad de todos y, por tanto, se aceptará 1) Que el Parlamento, la circunstancial mayoría parlamentaria, no es la encarnación de la soberanía sino un poder constituido sujeto a los límites constitucionales, pues de la Constitución y no de la directa voluntad popular deriva la legitimidad de sus competencias . (Hace falta una imaginación desbordante para suponer, prescindiendo de la imputación jurídica, que una decisión legislativa manifiestamente impopular y aprobada con votos de heterogénea procedencia, exprese la incontrolable voluntad del soberano. En cualquier caso, la situación carecería de toda verificación empírica y solo se podría hacer valer desde la supremacía de la Constitución y de las potestades que ésta reconoce. 2) Así las cosas, sería complicado negarle legitimidad para controlar los abusos de la mayoría a un órgano que goza de la misma legitimidad, a saber: No la que nace de una inexistente voluntad de un pretendido pueblo ( que en su existencia real no es sino una abigarrada, heterogénea, compleja y contradictoria suma de voluntades) sino la que nace de la única voluntad posible que es la creada a través del Derecho y concretada en la Constitución.

Desde estas premisas siempre me ha interesado, por sugestiva y bien fundada, la tesis de Ely (a la que antes me refería) que, concibiendo la democracia como procedimiento de toma de decisiones, defiende también la idea de «sociedad abierta» y reduce la legitimidad de la justicia constitucional al control de los derechos de participación política. La gran objeción que le encuentro a esta tesis — que en el fondo contrapone «democracia procedimental» a democracia material «como un orden sustantivo de valores»- es que me resulta imposible escindir los contenidos de la libertad. En suma, los derechos de participación política me resultan incomprensibles sin la garantía de los derechos informativos que hacen posible la libre formación de la opinión pública. Los derechos informa- 
tivos me resultan incomprensibles sin la garantía de la libertad de expresión y de su presupuesto lógico que es la libertad de conciencia... Y todos ellos me resultan difícilmente comprensible si al ciudadano, pretendidamente libre, no se le garantizan los derechos de la personalidad, su libertad y dignidad personal, el secreto de sus comunicaciones..., y, a su vez, no puedo dejar de contemplar esa libertad como una realidad vinculada a la situación social que condiciona, a veces hasta la determinación, las posibilidades reales de ser libre... Lo que llama a los derechos educativos, a una cierta protección frente el infortunio etc. Es esto lo que me lleva a no aceptar sin más la radical escisión entre democracia procedimental y democracia como orden material de valores. Y, lógicamente, a extender la legitimidad de la justicia constitucional a la totalidad de los derechos que una comunuidad política ha considerado, en un determinado momento histórico, como fundamentales.

Digamos, por penúltimo, que mi planteamiento está directamente vinculado al rechazo de la democracia directa como un imposible, no técnico, sino lógico. Es obvio que la democracia directa excluye de raíz la posibilidad de un control judicial de las decisiones del soberano. Como es obvio que la democracia directa configura un poder jurídicamente ilimitado y políticamente irresponsable por la elemental razón de que es un poder no ejercido por delegados sino directamente por el soberano. Sorprende por ello que tal forma de democracia de la identidad aún conserve enorme prestigio, como un «desideratum»ético y político en las sociedades democráticas (de la única democracia real que es la democracia representativa.) Sorprende que aún se afirme «que la democracia directa es más democrática que la representativa». Me temo que la democracia directa (salvo que uno se sienta cómodo con la democracia ateniense del siglo de Pericles - históricamente maravillosa, que supuso un increíble estallido de luz y de racionalidad en un universo de satrapías dominadas por «el mito»— que es una democracia radicalmente elitista, con fuertes contenidos totalitarios y absolutamente ignorante de los derechos de la persona frente a las exigencias de la comunidad) es un fantasma perturbador que planea sobre nuestra civilización impidiendo, entre otras cosas, que los graves problemas de representatividad de la democracia representativa se aborden desde su lógica interna y no desde la sombra de un centauro o una sirena inexistentes, puros frutos de la imaginación, sueños de una esperanza infundada.

Y digamos, por último, que este planteamiento que sostiene sin fisuras la legitimidad de la justicia constitucional y del control judicial de la constitucionalidad de la ley, dista de resolver los problemas de legitimación. Y ya he dicho que una severa deslegitimación no puede dejar de erosionar el principio de legitimidad pues, al cabo, nada más ilegítimo que lo innecesario, lo inútil o lo perturbador. Pero esta es, parcialmente, una cuestión distinta.

En efecto, todo lo dicho que, según creo, sostiene la legitimidad de la justicia constitucional, nada dice, sin embargo, de su adecuada configuración orgánica y funcional. Para empezar, no excluye la tensión práctica y política — en el fondo ineliminableno con el soberano pero si con una mayoría democráticamente legitimada (aunque sea una legitimidad que también nace de la organización constitucional). Nada dice del conflicto potencial entre la generación que tuvo la fortuna de protagonizar un proceso constituyente y las generaciones vivas — en terminología de Jefferson- que se encuentran relativamente encadenadas por la rigidez constitucional. Pero todas estas decisivas 
cuestiones, arrancan del reconocimiento de la legitimidad de la justicia constitucional y se esfuerzan en aliviar una inevitable tensión entre los tribunales y la mayoría parlamentaria a través de una depuración de la teoría de la «autocontención», de una sistematización objetiva de la necesidad y los límites de la «deferencia» de los tribunales con el legislador y aún de un posible diálogo, tácito o expreso (como en Canadá) entre el tribunal y el parlamento. (En España hay en esta materia, una extensa, sugestiva y excelente obra desarrollada por Victor Ferreres) A ella me remito.

II. El segundo cuestionamiento de la justicia constitucional (Del TCE y del control de las leyes) lo refiero exclusivamente a España y a algún tipo de leyes. Esta posición se expande, básicamente, a partir de la interposición del recurso contra la Ley orgánica que aprueba el Estatuto de Autonomía de Cataluña y plantea dos cuestiones: La improcedencia de revisar una ley «paccionada» como son, según se dice, las que aprueban estos Estatutos; y la improcedencia de revisar una ley que ha sido objeto de aprobación por el «pueblo» a través de referéndum. Como se ve, estas posiciones no niegan la legitimidad «general» del control de constitucionalidad de las leyes sino el de algunas leyes de especiales características. Veamos brevemente los dos supuestos.

1. Digamos, con inevitable simplificación, que en el primer supuesto subyace la idea de que los Estatutos de Autonomía son fruto de un pacto político entre el Estado español y la Comunidad Autónoma de naturaleza «cuasi» constituyente (en las posiciones más moderadas) o abiertamente constituyente para quienes sostienen una casi absoluta desconstitucionalización, en virtud de una peculiar interpretación del principio dispositivo, de la forma territorial del Estado. Desde estas premisas se sostiene, con coherencia lógica si se acepta la petición de principio, que este pacto no es susceptible de control jurisdiccional de constitucionalidad.

La idea del pacto político es una idea seriamente cuestionada y seriamente cuestionable. Por remitirnos al ejemplo real, no resulta nada fácil sostener que el nuevo Estatuto de Autonomía de Cataluña sea, jurídicamente, fruto de un pacto entre la «Entidad catalana» y el Estado español. Pero aún cuando esto fuere cierto, o jurídicamente sostenible, permanece un obstáculo insalvable para la defensa de la incontrolabilidad: Tal pacto ni es originario ni es fundacional. Tal pacto se enmarca en un pacto previo del que recibe su legitimidad, su alcance y sus límites. Me refiero, obviamente, al pacto constituyente... Y es éste el que determina la controlabilidad y el que suministra los parámetros de enjuiciamiento.

2. Respecto a la incontrolabilidad jurisdiccional de las leyes refrendadas, hay que distinguir nítidamente dos supuestos: cuando quien actúa es el cuerpo electoral global, es decir, el conjunto de la ciudadanía del Estado que se configura constitucionalmente como el titular de la soberanía nacional, y cuando actúa un cuerpo electoral de ámbito territorialmente restringido que en ningún caso se confunde con la nación española.

En el primero de los casos se puede debatir si ese cuerpo electoral es el soberano y su decisión incontrolable. Así lo entendió el Consejo Constitucional francés en el referéndum (formalmente inconstitucional puesto que no era el cauce habilitado para la reforma de la Constitución) que aprobó la elección por sufragio universal del Presidente de la República francesa. Sin duda, pesó en el ánimo del Consejo, para entender que se encontraba ante un acto revolucionario del poder constituyente, la fortísima participación y la abrumadora mayoría del voto favorable. Pero con independencia del caso francés, ni si- 
quiera esto está claro. Se puede sostener sin demasiadas dificultades teóricas que el «cuerpo electoral», salvo cuando actúa en el procedimiento de revisión constitucional, no pasa de ser un órgano constituido y sus decisiones perfectamente controlables. Que incluso se le puede controlar, en el caso de vicios de procedimiento, cuando actúa como poder constituyente, e incluso - para quien sostenga que toda democracia es con necesidad lógica una democracia militante- por vicio material cuando la reforma viola contenidos esenciales de la democracia.

Pero, cualquiera que sea la postura que se sostenga en estas materias, el supuesto del referéndum catalán no admite polémica alguna, pues, con toda evidencia, esa fracción del cuerpo electoral jamás podría actuar como poder constituyente mientras la Constitución siga proclamando que la soberanía nacional resida en el pueblo español. Se trató, pues, del acto de un poder constituido sujeto a la Constitución y al control del supremo intérprete de la misma. Y ello sin extenderme en la idea de que ese Estatuto refrendado por el pueblo catalán contenía disposiciones que afectaban abiertamente a ciudadanos de otras comunidades que no tuvieron ninguna oportunidad de pronunciarse sobre él.

\section{B) Problemas de legitimación}

Hemos sostenido que en buena teoría no se puede cuestionar la legitimidad del TC, en particular del control de constitucionalidad de las leyes que es, obviamente, el que plantea mayores dificultades en su compatibilidad con el principio democrático. Siendo, como es, el de legitimidad un concepto normativo no es mesurable, no admite grados; o se tiene o no se tiene. Por el contrario, la legitimación, que es un concepto sociológico, sí resulta mesurable y graduable; aumenta o disminuye y es menester ganarla día a día mediante un funcionamiento correcto de la institución que sea socialmente percibido como eficaz.

Pues bien, como ya se ha dicho, el TCE ha venido sufriendo un proceso de constante y creciente deslegitimación, de pérdida de prestigio y respeto, de extremada gravedad, hasta el punto de amenazar la estabilidad de todo el sistema. Tratando de sistematizar en la medida de lo posible y en la medida de mis fuerzas, lo que, según creo, son algunas de las causas de este deterioro constante, podríamos hablar de las siguientes: - Incumplimientos de la Constitución tanto formales como materiales, tanto del tenor literal de la norma como de su espíritu; —Problemas de funcionamiento que siembran dudas sobre la eficacia de su función; - Resoluciones altamente conflictivas que causan malestar y rechazo social, ya sea porque se perciban como una insuficiente defensa de la Constitución o como un exceso poco respetuoso con la deferencia debida al legislador democrático. (No es infrecuente que en el rechazo social — como ocurrió con la sentencia sobre el Estatuto de Cataluña - coincidan ambas apreciaciones contradictorias distribuidas entre distintos sectores sociales y políticos en función de sus expectativas. En estos casos la pacificación política resulta siempre imposible porque no puede depender de la función jurisdiccional sino de algo previo y fundante como es la negociación y el acuerdo político, lo que, en el caso catalán, no se produjo y, me temo, ni siquiera se buscó.

A su vez, estos causales, pueden provenir de comportamientos externos a la institución (del Gobierno, del Parlamento, de los partidos políticos, de los medios de comunicación etc.) a los que denominaré causas externas; o del propio interior del órgano, causas internas. 
Por razones de claridad expositiva voy a utilizar este último criterio clasificatorio utilizando la diferencia entre causas externas e internas. Además, solo analizaré en esta primera respuesta de carácter general, las que no sean objeto de preguntas específicas y ulteriores como, por ejemplo, las provenientes — siempre externas — de las reformas legislativas de la LOTC.

\section{A) Causas externas}

Son sin duda las que con mayor intensidad han erosionado el prestigio del TC. Entre ellas, me referiré posteriormente, al responder a otras preguntas, a las que traen causa de desafortunadas reformas legislativas. Ya me he referido (en el largo párrafo transcrito de mis respuestas a la encuesta del $n^{\circ} 21$ ) al pesado fardo que se echa sobre los hombros del Tribunal cuando se le trasladan conflictos políticos en los que ni hay ni a veces se ha buscado el consenso. En las dos últimas legislaturas hemos asistido, por primera vez en la democracia, a la aprobación unilateral, sin el menor consenso, de leyes que, como las que aprueban los EEAA o las que han reformado la LOTC, aunque no sean formalmente constitucionales, son normas institucionales básicas que reclaman el mayor consenso. De las tres reformas últimas de la LOTC (la amplia del 2007 sobre el nuevo amparo, la prórroga de los mandatos de Presidente y Vicepresidente y la intervención de las Comunidades Autónomas en la elección de los Magistrados correspondientes al tercio del Senado, la de primeros de 2010 sobre la atribución de competencias al Tribunal para controlar las normas forales fiscales vascas, y la de otoño de 2010 para acortar el mandato de los Magistrados cuando haya retraso en la renovación) sólo la última lo fue por amplísimo consenso, mientras que las dos primeras lo fueron prácticamente por la mínima mayoría constitucionalmente prevista y con el rechazo del principal partido de la oposición.

No es buena práctica, ni se corresponde con el espíritu constitucional, introducir reformas - máxime de este calado — en la LOTC sin consenso entre los dos grandes partidos nacionales. De no ser así, aunque tales reformas sean válidas, pierden legitimación, porque la regulación de un órgano de la importancia del TC nunca debe ser el resultado de la simple voluntad de la mayoría más uno del Congreso de los Diputados. No quiero ni imaginar el destino de nuestra democracia si cada partido capaz de encontrar un apoyo numéricamente suficiente, hubiese procedido a acomodar el sistema electoral a sus intereses políticos. Y esto es lo que se ha hecho con la LOTC.

También me he referido ya de forma sucinta, en el párrafo citado, a la responsabilidad de los «medios» en la difusión machacona de unos rígidos alineamientos ideológicos y políticos entre conservadores y progresistas, que transmiten, con razón o sin ella, el más perturbador de los mensajes: la falta de independencia. Tampoco están exentos de responsabilidad los medios en las tremendas presiones, que han llegado a incluir fuertes descalificaciones personales con campañas de desprestigio absolutamente orientadas y dirigidas, o abiertas manipulaciones, que han ejercido sobre el Tribunal siempre que nos encontrábamos ante un caso políticamente conflictivo.

Lo mismo puede decirse de las organizaciones políticas, singularmente los partidos, y, lo que es peor aún, de altas autoridades del Estado, que han llegado a presionar al Tribunal con verdadera deslealtad institucional. 
Pero, con todo, el problema más intenso proviene de la partidocracia que se ha apoderado de nuestro sistema político y que ha contribuido de la forma más intensa, con sus nombramientos, con sus demoras, con sus presiones y manipulaciones, a pervertir la institución y a incumplir flagrantemente la Constitución.

Hace unos años, escribiendo sobre nuestra forma de gobierno, sostenía que, en esta materia, la transición había sido presidida por dos fantasmas obsesivos que descansaban, el primero en una percepción equivocada de la realidad y el segundo en una percepción certera pero sujeta a plazo de caducidad — certus an et incertus quando-.

El primer fantasma, que se reveló infundado, era la creencia de que la sociedad española estaba políticamente muy fragmentada tanto por razones ideológicas como por la superposición de los sentimientos nacionalistas y regionalistas. Se temía que tal fragmentación se proyectase en el Parlamento y apareciese un cierto desequilibrio asambleario. De aquí la obsesión en la configuración de un Ejecutivo fuerte utilizando sin matices todas las técnicas del parlamentarismo racionalizado. Luego, la realidad y los efectos del sistema electoral, lo que provocaron fue todo lo contrario: una fuerte tendencia al bipartidismo y a las mayorías absolutas, con algunos efectos altamente disfuncionales. Pero no es este fantasma el que ahora nos interesa.

El segundo fantasma, la segunda obsesión, descansaba en la percepción certera de que una democracia de masas no podría funcionar sin un sólido sistema de partidos fuertes. Tras cuarenta años de dictadura había que consolidar organizaciones muy débiles o recién nacidas. Los partidos van a disfrutar de toda clase de ventajas, políticas, jurídicas y económicas. Una financiación generosa y poco controlada, una legislación generosa en todos los ámbitos pero especialmente en el derecho parlamentario y la posición de los grupos, una práctica ausencia de todo control sobre su funcionamiento interno, unas listas cerradas y bloqueadas en las elecciones al Congreso, a los Parlamentos autonómicos y a las corporaciones locales, sistema que favorece abiertamente la férrea disciplina y la oligarquización de las organizaciones, etc. etc.

Pero, como hemos dicho, la percepción estaba sujeta a plazo de caducidad. A comienzos de los años 90 el sistema de partidos es sólido y estable y las organizaciones partidarias muestran clara tendencia a apoderarse de todos los ámbitos del Estado, a controlar todas las instituciones. Ello se hace notar pronto con el apoderamiento partidario del Consejo General del Poder Judicial como vía, fundamentalmente, de controlar al propio Poder Judicial a través de los nombramientos... Y culmina con el reparto entre los dos grandes partidos, con alguna concesión menor al nacionalismo, de las vacantes del TC. Y no se puede olvidar que en la lógica interna de partidos tan cerrados y sometidos a tan férrea disciplina, la identidad ideológica prima sobre las cualidades intelectuales y morales, y la obediencia o la «lealtad» a quien los nombró prima sobre el espíritu abierto y la independencia radical. No es de extrañar que se hayan ido produciendo crecientes alineamientos, no sin muy honorables excepciones, en bloques compactos generados por la procedencia del nombramiento. La deferencia debida al legislador no siempre es objetiva y estable sino que se vislumbra el riesgo de que dependa de la orientación política del legislador.

Si el primer Tribunal nació enfrentándose al Gobierno e imponiendo su autonomía institucional en la elección del Presidente, en un claro ejemplo de independencia política, me temo, con el máximo respeto a las personas, que el funcionamiento ya no resulta tan 
ejemplar. Con unos se muestra la mayor «deferencia», el mayor respeto a su libertad política de configuración, y a otros se les aplica el más riguroso de los parámetros de constitucionalidad.

Me detengo a reflexionar y me pregunto si mi juicio no es desmesurado. No quiero ofender a nadie ni contribuir a la deslegitimación del Tribunal y no tengo inconveniente en moderarlo y sembrarlo de matices. Pero esta no es la cuestión. Mi juicio puede llegar a ser mucho más matizado pero mi personal opinión es muy poco relevante. El problema del TC, su grave problema, es que la opinión vertida es la que, con independencia de lo que yo opine, ha arraigado en la opinión pública e, incluso, en la mayoría de la comunidad jurídica. Ese es su problema en la lucha diaria por su legitimación.

Pero aún se debe ahondar en ese juicio: las designaciones de los Magistrados a través de cuotas de partido, algo que ni es adecuado ni es el sistema que la Constitución ha previsto — que se basa en el consenso y no en el reparto- de tal manera que lo correcto sería que todos los designados, uno a uno, tuviesen el respaldo de los dos grandes partidos. Así se compuso el primer Tribunal y así debiera de haberse compuesto desde entonces. Pero lamentablemente el sistema de designación ha sido pervertido por la «partidocracia».

Además, la erradicación de las «cuotas de unilateral disposición» conduciría con más facilidad a que los Magistrados reúnan realmente los requisitos que la Constitución exige. No se trata sólo de tener más de quince años de ejercicio profesional, que obviamente hay que cumplirlo, pero que es un requisito de carácter burocrático o cuantitativo que por si sólo no garantiza la idoneidad del Magistrado. Sino, sobre todo, el requisito más importante, en cuanto que es de naturaleza cualitativa: Ser jurista «de reconocida competencia», es decir, de auténtico reconocimiento, como autoridad en Derecho, por la comunidad de juristas. Personas así, fuera de toda sospecha de parcialidad, desligadas de intereses partidistas, obrarán, presumiblemente, con la objetividad y la independencia que el cargo exige.

Digamos por último que los efectos perversos de la partidocracia, y del conjunto del sistema de cuotas, no se agotan en la forma de designación. La permanente búsqueda de un Tribunal obediente, o influenciable o ideológicamente afecto, conduce al cálculo sobre el momento de la designación. Esta es la principal causa de la creciente falta de respeto a los plazos constitucionales y legales. Frente a la inequívoca obligación constitucional y legal de proceder a una propuesta de designación en tiempo y forma ha prevalecido el cálculo político sobre la posibilidad de obtener — en función de las expectativas de llegar a ser Gobierno, de ser mayoría en las Cámaras o de controlar el Consejo General del Poder Judicial - una designación favorable. Esta es la clara explicación de los tremendos retrasos en la designación de Magistrados, de las prórrogas de mandatos y, en suma, de la desnaturalización de la previsión constitucional.

\section{B) Causas internas}

Cuando en el año 2008 respondí a la Encuesta del nº 21 entendía que lo que fundamentalmente estaba erosionando la legitimación del TC eran comportamientos y actos externos al órgano (provenientes del Gobierno, del Parlamento, de los partidos políticos, de la clase política, de los medios de comunicación...) aunque no dejara de reseñar alguna cau- 
sa interna derivada del funcionamiento del propio Tribunal. Hoy día entiendo que la erosión y el desprestigio crecientes le deben también mucho a dicho funcionamiento interno:

1. Ya indicaba en aquellas respuestas la perdida de eficacia reparadora como consecuencia del creciente retraso y la acumulación de casos pendientes de resolución. (Volveré sobre ello al hablar de la reforma del recurso de amparo). Pero, en cualquier caso, las demoras más nocivas para el sistema no son las que se producen en el amparo, aunque el crecimiento exponencial de la litigiosidad en esta vía con el consiguiente aumento de la carga de trabajo, explique parcialmente el retraso en los asuntos de Pleno. Esta explicación, aunque merecedora de toda comprensión, es insuficiente porque, en alguna medida, existe la posibilidad de establecer prioridades y administrar la urgencia diferenciando los casos que se limitan a la reparación de un derecho singular, por trascendente que esto pueda llegar a ser, de aquellos otros que condicionan con carácter general la seguridad jurídica y tienen por objeto la determinación de la validez de normas generales o del ejercicio de competencias.

Seriamente llamativo y hondamente deslegitimador ha sido el enorme retraso en la resolución del recurso contra el nuevo Estatuto de Cataluña. Hay, ciertamente, atenuantes pero de ninguna manera eximentes. La responsabilidad es difícilmente negable. Es una atenuante el esfuerzo desplegado (sin demasiado éxito aunque con alguno muy relevante) en la búsqueda de consensos básicos que evitaran la imagen de un órgano fracturado y férreamente alineado en bloques. Son una atenuante los retrasos procesales provocados por la presión externa para manipular la composición del Tribunal a través de diversas recusaciones. Son, en fin, una atenuante, las vacilaciones provocadas por las fracasadas expectativas de una amplia renovación del Tribunal teóricamente obligada por el fallecimiento de un Magistrado del tercio del Congreso y el fin del mandato de los cuatro del tercio del Senado. Pero todas estas causas atenuantes no justifican el desmesurado retraso en un recurso de enorme trascendencia jurídica y política.

2. Desde hace algunos años el TC se ha mostrado, en sentencias de calado político y de gran impacto en la opinión pública, fracturado en bloques de comportamiento más o menos previsible. Con alguna excepción - muy singularmente en el caso de Aragón Reyes - la imagen transmitida a la opinión pública es la de bloques políticamente alineados con quienes les nombraron. Es muy posible que en algunos casos (o en muchos) este juicio pueda resultar desmesurado o abiertamente injusto; es posible que los alineamientos tengan que ver con legítimas sensibilidades jurídicas y no con obediencias políticas... Pero el hecho, radicalmente deslegitimador, es que la percepción social ha venido siendo de falta de independencia. Es esta una imagen demoledora que, aún cuando fuere falsa e injusta en el caso de algunos o muchos Magistrados, ha arraigado en la opinión pública y en gran parte de la comunidad jurídica. Y esta percepción no puede desautorizarse sin más con apelaciones personales a la integridad. No dudo de la de nadie mientras no se demuestre lo contrario. Pero no es ese el problema. El problema es la percepción social, y esa percepción tiene indudable anclaje objetivo en dos datos: los alineamientos previsibles en bloques (que por si sólos admiten muchas explicaciones legítimas) sumados al comportamiento de los partidos en la selección de sus candidatos con prácticas, como veremos, crecientemente alejadas del espíritu constitucional. Creo que el primer hecho, por si sólo, no hubiera generado tan negativa imagen. Es el segundo el que siembra una sospecha no absolutamente infundada sobre las razones del primero. 
3. También le son reprochables al Tribunal o a alguno de sus miembros ciertos comportamientos, o ausencia de ellos, que han ayudado poco a la institución. Voy a referirme concretamente a dos.

a. En primer lugar, a la falta de respuesta del Tribunal ante la insoportable situación de retrasos en las renovaciones. Es cierto que en alguna ocasión el Tribunal ha conminado, incluso por escrito, a los órganos constitucionales concernidos (al menos así lo recogió la prensa sin que nadie lo desmintiera) para que pusieran fin a esos retrasos, pero, ante el nulo resultado de estas «admoniciones», el Tribunal acaso hubiera debido reaccionar de manera más contundente lo que, sin embargo, no hizo.

Desde el punto de vista individual de cada Magistrado, quizás aquellos que vieron excesivamente (habría que decir desmesuradamente, porque estamos hablando de un retraso de más de tres años en lo que respecta a los elegidos por el Senado) retrasada su sustitución debieron presentar, desde una postura de firmeza, una pública dimisión para dejar constancia de la »inconstitucionalidad» de su situación. No sé el efecto que hubiera tenido pero sí creo, con absoluta convicción, que el gesto realizado a tiempo hubiera contribuido al prestigio del Tribunal.

Lo mismo se pudo decir durante seis meses de los tres Magistrados del turno del Congreso cuyo mandato estaba ampliamente caducado a lo que se añadía el agravante del correlativo acortamiento del mandato de quienes hayan de sucederles.

Ahora bien, estas son posibles reacciones personales que incumben en conciencia a los Magistrados afectados y no, claro está, al Tribunal en su conjunto. Sin embargo, el Tribunal sí ha tenido una ocasión de afirmar su dignidad e independencia haciendo patente que no estaba dispuesto a soportar los retrasos pero, lamentablemente, no lo hizo. Cuando se produjo la renovación por el Senado (por fin y con más de tres años de retraso) y cesaron la Presidenta y el Vicepresidente (cuyos mandatos de tres años se vieron prorrogados sin intervención del Pleno del Tribunal nada menos que hasta seis años y medio, algo totalmente anómalo e inaudito) el Tribunal no debió de elegir a unos nuevos Presidente y Vicepresidente.

En efecto, una vez que la Presidenta saliente —en su discurso público en el acto solemne, del pasado mes de enero, de toma de posesión de los nuevos Magistrados- calificó, con dureza y absoluta precisión, la situación de retraso como un claro y grave incumplimiento de la Constitución, llegando a afirmar que ello suponía un importante quebranto para nuestro sistema constitucional democrático (intervención que tuvo un amplio e intenso eco en los medios de comunicación) y una vez que, a continuación, el entrante Presidente en funciones — por razón de antigüedad y edad- quiso dejar constancia expresa en su breve intervención de que el Tribunal se encontraba en una situación contraria a la Constitución, incompleto por la no sustitución desde hacía tres años de un Magistrado fallecido y con tres miembros más cuyo mandato ya estaba caducado. Tras estas graves constataciones y calificaciones, el Tribunal no hubiera debido de actuar con «regularidad» convalidando así una situación «irregular». Era su ocasión para hacer valer, por fin, su enérgico desacuerdo con lo que estaba sucediendo y para defender su dignidad institucional. No se encontraba, pues, el Tribunal, en una situación «ordinaria» sino «excepcional» y, por ello, hubiera debido haberse negado a cooperar para que aquella situación se prolongase, sino que, supremo guardián de la Constitución, hubiera debido de haber actuado para que aquella inconstitucional situación desapareciese. La 
LOTC le facilitaba el camino: En situación excepcional lo que cabe es la Presidencia y la Vicepresidencia de edad (arts. 6.2 y 7.3). Así pues, no elección sino mera designación ope legis, dejando constancia pública de que el Tribunal Constitucional no podía dotar de «regularidad» a una situación de profunda «irregularidad», y de que se le daba al Congreso de los Diputados un plazo perentorio para que procediera a la renovación y así el Tribunal quedase en la situación que la Constitución impone. Este acto de fuerza «constitucional» (incluso con la amenaza de dimisiones si no surtía efecto) hubiera logrado, probablemente, su objetivo y, sobre todo, le habría dado al Tribunal algo del prestigio de cuya creciente falta adolece.

Lamentablemente nada fue como debiera. Muy al contrario, el Tribunal, convalidando una vez más la anormalidad, actuó como si nada ocurriera, y no sólo eligió a un nuevo Presidente sino también a un Vicepresidente que, en el colmo de la complacencia con la irregularidad, era uno de los Magistrados con mandato caducado y prorrogado.

La situación se hizo tan insostenible que los tres Magistrados prorrogados, provenientes del «tercio del Congreso», ya incompleto por el fallecimiento de García Calvo, presentaron su dimisión en el mes de junio. De estas dimisiones una era esperable y otra un tanto sorprendente, al menos en los términos en que se produjo. Era esperable la de Javier Delgado porque hay constancia de que llevaba seis meses solicitando encarecidamente su sustitución de acuerdo con las previsiones constitucionales. Sorprenden los términos de su ¿dimisión? y las declaraciones de Eugenio Gay que acompañan a aquella. Sorprende que haya afirmado que llevaba tiempo diciéndoles a sus compañeros que se sentía miembro «de un Tribunal secuestrado». Llama poderosamente la atención que alguien con el mandato prorrogado y con tan penosa sensación acepte sin el menor reparo ser elegido Vicepresidente de ese Tribunal «secuestrado». También los gestos de incoherencia contribuyen al desprestigio del Tribunal.

Es sabido que esas dimisiones no fueron aceptadas por el Presidente, aunque eran un importante medio de presión sobre los verdaderos responsables de la permanente irregularidad. No obstante, dada la trayectoria de unos comportamientos partidistas al servicio de la estrategia de controlar o al menos influir en el Tribunal, y dada la proximidad de elecciones generales y de las expectativas que ellas generan, no puedo ser muy optimista sobre la fuerza persuasiva de esas dimisiones no aceptadas.

Pero, aún así, me pregunto porqué no fueron aceptadas. Era una nueva y extraordinaria ocasión para que, en un acto legítimo de fuerza, el Tribunal exigiese la normalidad y reivindicase su dignidad institucional ¿Por qué no se aceptaron y se situó al Congreso de los Diputados y a los partidos políticos ante su grandísima irresponsabilidad?

No se puede sostener que dicha aceptación hubiera causado daños mayores de los que se hubiera debido de paliar. Si no malinterpreto la LOTC tras sus últimas reformas, la situación es la siguiente: El art. 17.2 dota de cobertura legal a una situación de hecho procediendo a dar cobertura normativa a una prórroga automática del mandato caducado hasta la toma de posesión de los sucesores, pero en nada altera la regulación de las diversas situaciones de los Magistrados, entre ellas el cese. Es decir, con mandato genuino o con mandato prorrogado, las causas de cese de los Magistrados, incluida la renuncia, siguen siendo las mismas, las contempladas en el artículo 23.1. En el caso de renuncia, que es el de las dimisiones presentadas, de acuerdo con el mismo precepto, corresponde al Presidente su aceptación o rechazo. La Ley no introduce criterio alguno para esta decisión 
por lo que hay que entender que existe una total capacidad del Presidente para valorar la oportunidad de la dimisión y aceptarla o no. Sabemos que el Presidente no aceptó las dimisiones.

A mi juicio, y desde el máximo respeto a la libertad de apreciación del Presidente, fue, como ya he dicho, una nueva oportunidad perdida para reivindicar la dignidad del Tribunal. Los efectos negativos de las dimisiones hubieran sido menores por cuanto no afectarían al quórum necesario para la toma de decisiones ni del Pleno ni de las Salas ya que, de acuerdo con el art.14 de la LOTC, dicho quórum se computa a partir de los Magistrados que en cada momento compongan el órgano. Tan solo se podría ver afectado el ritmo de trabajo y el número de resoluciones pero, con la tradición de morosidad que el Tribunal arrastra, una limitada ralentización durante un breve espacio temporal no me parece un argumento de suficiente peso frente a la necesidad de forzar por todos los medios legítimos la normalización del Tribunal. Claro que, y acaso esta idea tuviese peso en la decisión, la aceptación de las tres renuncias afectaba al equilibrio de bloques, «si tal cosa existe», en detrimento de el que, «de existir», sería el bloque del Presidente.

En estas condiciones $¿$ a alguien le puede parecer imprudente, osado o excesivo, sospechar que, a salvo la dimisión de Delgado, nos encontramos ante una escenificación pactada?

b. Digamos por último, que tampoco ayuda a la respetabilidad del Tribunal la permanente filtración a los medios de comunicación y a la clase política de documentos y deliberaciones sujetas a secreto. (Cuando estoy cerrando esta líneas se acaba de producir la filtración de un documento sobre un caso que afecta a la llamada «doctrina Parott»).

Sin duda es un problema nada fácil poner coto a estas filtraciones, como ocurre con el quebrantamiento del secreto de los sumarios, pero lo que no tiene ni gracia ni fundamento es acabar echándole la culpa al bedel. No pocas veces se han filtrado intervenciones en las deliberaciones del Pleno, incluso con palabras reproducidas textualmente. Esto no pudo ser obra más que de un Magistrado. Estas situaciones, a parte de suponer un grave quebrantamiento del deber de secreto, merman severamente la respetabilidad del Tribunal. No puede exigir respeto quien no se comporta de manera respetable.

4. Una importante causa de deslegitimación es una jurisprudencia, máxime si es fruto de un Tribunal fracturado, percibida por amplios sectores sociales y «de la comunidad jurídica» como falta de fundamento o excesivamente complaciente con los intereses del Gobierno o de la mayoría parlamentaria; cuando se extiende la sospecha de que se está traspasando la frontera de la deferencia hacia el legislador para entrar en el terreno de la reverencia.

No creo que sentencias como la de la «violencia de género» en la que se acepta algo tan incuestionablemente reaccionario como la modulación de la responsabilidad criminal en función del dato anatómico y fisiológico del sexo, viniendo a resucitar una especie de «delito de estirpe»... O sentencias como la del «caso Bildu» en la que se descalifica de forma impertinente al Tribunal Supremo pese a que se ha limitado a ser fiel con una jurisprudencia del propio Tribunal Constitucional (sentada fundamentalmente en recursos de amparo en el ámbito del Derecho Administrativo sancionador) sobre el valor de la prueba de presunciones a partir de pruebas indiciarias, únicas posibles cuando el ilícito reprochado procede del fraude y, por tanto, del engaño y la simulación... U 
otras muchas dictadas con un Tribunal dividido y por apretada mayoría... No creo que este tipo de sentencias, sobre todo cuando se hacen frecuentes, favorezca la legitimación del Tribunal.

En todo caso, un reproche serio y ponderado en materia de doctrina jurisprudencial requiere, para no incurrir en frivolidad o para no sobrevalorar sin fundamento la opinión propia, de una crítica bastante más minuciosa de la que permite la respuesta a una Encuesta de esta naturaleza.

Me parece mucho más importante poner de relieve otro riesgo, que implicaría un reproche de mayor gravedad que el que pudiera derivarse de mi personal juicio sobre sentencias concretas, que bien pudiera estimarse irrelevante. Me refiero a una cierta inseguridad jurídica derivada de la fractura del Tribunal y de la sospecha de que se está librando una batalla interna, fomentada por permanentes ingerencias externas, que hace temer un riesgo intolerable: el de los bandazos infundados e inexplicados de la jurisprudencia constitucional. Me explico:

Uno de los mayores servicios que un Magistrado puede prestar a la objetividad y racionalidad del sistema de justicia constitucional, y a su función pacificadora, es saber alinearse, tras defender su discrepancia y plasmarla en un voto particular, con la posición que pasa a ser la oficial del Órgano, reintegrarse a la línea jurisprudencial establecida y a la doctrina sentada. Es una forma de hacer explícita la idea de que la primera independencia exigible al juez es la independencia frente a si mismo, a sus preferencias, prejuicios o convicciones, precisamente porque está obligado a sacrificar su voluntad para aplicar una voluntad ajena que es la que le confiere su legitimidad.

Permítaseme que, entre los muchos posibles, ponga un ejemplo que estimo luminoso. Uno de los temas política y jurídicamente más conflictivos en España ha sido el educativo. En el año 1981 el TC se pronunció sobre un recurso presentado por más de sesenta Senadores socialistas contra la Ley Orgánica del Estatuto de Centros Escolares. Recayó la ponencia en quien años después sería un competente y notable Presidente del Tribunal, Francisco Tomás y Valiente. Su ponencia fue aceptada por el Pleno en gran parte, pero no en lo que se refería al primer motivo del recurso que contemplaba el «ideario educativo» de los centros privados. No era una cuestión menor sino que estaba en el mismo corazón de la polémica que enfrentaba a la UCD y al PSOE (y, en general, a la derecha y a la izquierda españolas). Se le encomendó esta parte de la ponencia al Magistrado Rubio Llorente, fue aceptada su propuesta y el Pleno dictó sentencia por mayoría. El Magistrado Tomás y Valiente emitió voto particular al que se adhirieron otros tres Magistrados poniendo de relieve la división del Tribunal. Pero la discrepancia no pasó de aquí. Esta minoría aceptó la doctrina sentada y no volvió a formular discrepancias. Cuando en el año 1985 el Tribunal conoció el recurso contra la LODE, reiteró su doctrina jurisprudencial sentada en la sentencia sobre la LOECE en 1981 sobre el «ideario de centro», y el Magistrado Tomás y Valiente aceptó sin problemas la jurisprudencia establecida y ya no emitió voto particular alguno.

El servicio que prestan este tipo de comportamientos a la pacificación de los conflictos y a la seguridad jurídica, es impagable. No hace falta ser discípulo de Olivecrona ni tener una concepción sociologista del Derecho, para comprender que la seguridad jurídica descansa en la previsibilidad de unas decisiones judiciales fundadas en un razonamiento objetivado y objetivable. 
Pues bien, y por ejemplo, ¿Se puede sostener hoy con seguridad que este TC, fracturado e invadido, va a mantenerse leal a la doctrina jurisprudencial sentada en la resolución del recurso contra el Estatuto de Cataluña? ¿Sería una sospecha radicalmente infundada el temor a que se pueda pretender componer una nueva mayoría y «reinterpretar» en sentido contrario esa doctrina? Por supuesto, sería una reinterpretación ni confesada ni motivada, sino simplemente enmascarada en retórica más o menos huera. Ojalá me equivoque.

\section{ViCENTE GIMENO SENDRA}

Efectivamente han existido presiones intolerables por parte de los partidos políticos mayoritarios y, en menor medida, de los nacionalistas.

Las causas de tales ataques a la autoridad del Tribunal Constitucional las situaría en la «politización de la justicia», derivada de la falta de respeto, por parte de los referidos partidos políticos hacia el Poder Judicial, en general, y al rol de árbitro moderador del Tribunal Constitucional, en particular.

\section{JAVIER PÉRez Royo}

Independientemente de que se esté de acuerdo o no con la sentencia dictada por el Tribunal Constitucional en el recurso de inconstitucionalidad interpuesto por diputados del PP contra la reforma del Estatuto de Autonomía para Cataluña, parece fuera de duda que el prestigio e incluso la legitimidad del Tribunal Constitucional se han visto afectados de manera significativa. Los indicios de que así ha sido son abrumadores. Tanto que no es necesario recordarlos de manera individualizada para el público al que va dirigida esta revista. En todo caso, el hecho de que el Consejo de Redacción de la Revista haya considerado oportuno hacer una encuesta como ésta y que su primera pregunta haya sido formulada en los términos en que lo ha hecho, es una prueba concluyente de la percepción que existe y de la preocupación que se tiene por esa pérdida de prestigio y legitimidad.

Difícilmente podía haber sido de otra manera, pues la reforma del Estatuto de Autonomía para Cataluña no debería haber acabado nunca ante el Tribunal Constitucional. El constituyente definió el Estatuto de Autonomía del artículo 151 CE como un pacto de naturaleza política entre el Estado y la nacionalidad o región que decide constituirse en Comunidad Autónoma por dicha vía. El Estatuto del artículo 151 CE es el resultado de un compromiso entre el principio de unidad política del Estado y el ejercicio del derecho a la autonomía. El principio de unidad opera como presupuesto y límite del ejercicio del derecho a la autonomía. Solamente aquel ejercicio del derecho a la autonomía que resulte compatible con el principio de unidad política del Estado resulta constitucionalmente aceptable. Pero la imposición del principio de unidad política del Estado no puede llegar a tal extremo que el resultado no resulte aceptable para la nacionalidad o región titular del derecho a la autonomía.

Esta es la razón por la que el constituyente español, diferenciándose en esto de la experiencias conocidas en derecho comparado, impuso la colaboración del Estado a través de 
las Cortes Generales y de la nacionalidad o región a través de su Parlamento en la elaboración y reforma de los Estatutos de Autonomía en general y, sobre todo, de los Estatutos del artículo $151 \mathrm{CE}$. La nacionalidad o región necesita del concurso del Estado para ejercer su derecho a la autonomía. Y además, en caso de desacuerdo entre el Estado y la nacionalidad o región, es la voluntad del Estado la que se impone. En caso de conflicto entre el principio de unidad política del Estado y el derecho a la autonomía, es el primero el que prevalece. En ningún caso, en el proceso estatuyente o de reforma estatutaria, puede imponerle la nacionalidad o región su voluntad al Estado.

Esta es la primera garantía que figura en la Constitución en el proceso de construcción del Estado Autonómico. Garantía de la unidad política del Estado, de la que se hace guardián a las Cortes Generales, único órgano constitucional del que la Constitución dice que «representan al pueblo español» (art.66.1 CE).

Pero no es esta la única garantía que contempla la Constitución. Junto a ella figura otra que juega a favor del derecho a la autonomía. Dicha garantía consiste en que el pueblo de la nacionalidad o región que ejerce el derecho a la autonomía por la vía del artículo 151 CE tiene siempre la última palabra en el ejercicio de dicho derecho. En caso de desacuerdo entre el Estado y la nacionalidad o región, es decir, entre las Cortes Generales y el Parlamento de la Comunidad Autónoma, se impone, como ha quedado dicho, la voluntad de las Cortes Generales, pero el texto aprobado unilateralmente por las Cortes Generales tiene que ser sometido a referéndum de la población de la nacionalidad o región que puede ratificarlo o rechazarlo.

La construcción del Estado Autonómico descansa en una doble garantía. Una a favor del principio de unidad política del Estado. Otra a favor del derecho a la autonomía. Ni la nacionalidad o región puede imponerle al Estado la aceptación de un Estatuto de Autonomía que el Estado considere lesivo del principio de unidad, ni el Estado puede imponerle a la nacionalidad o región un Estatuto que los ciudadanos de dicha nacionalidad o región consideren lesivo de su derecho a la autonomía.

Este compromiso entre unidad y autonomía estuvo presente ya en el primer Proyecto de Constitución, el que se publica en el Boletín Oficial de las Cortes el 5 de enero de 1978 y no dejó de esta presente en ningún momento del iter constituyente hasta el texto definitivo sometido a referéndum el 6 de diciembre de 1978. En el artículo 2, en el artículo relativo al Senado y en los artículos del Título VIII así como en las Disposiciones Adicionales y Transitorias hubo muchos cambios a lo largo del iter constituyente, pero en la definición del compromiso entre el principio de unidad y el derecho a la autonomía mediante esta doble garantía no hubo ninguno. Se puede identificar perfectamente la voluntad constituyente. Aquí no hay la más mínima duda.

El Estatuto de Autonomía del artículo $151 \mathrm{CE}$ y su reforma es el resultado de la confluencia de tres formas distintas del principio de legitimación democrática, en el que descansa todo nuestro sistema político y nuestro ordenamiento jurídico. La primera es la legitimación democrática del pueblo español, de la que son portadoras las Cortes Generales y las otras dos son expresión de la legitimidad democrática del pueblo de la nacionalidad o región, de las que son portadoras el Parlamento de la Comunidad Autónoma y el pueblo de la nacionalidad o región directamente en referéndum.

Esta es la naturaleza del Estatuto de Autonomía del artículo 151 CE. No hay ninguna otra norma que pueda comparársele. Decir que la naturaleza del Estatuto de Au- 
tonomía del artículo 151 CE es la de una Ley Orgánica es absurdo. Una Ley Orgánica es expresión de una única forma de manifestación del principio de legitimidad democrática y no puede ser nunca el resultado de un pacto entre tres formas distintas de expresión de dicho principio.

Esta es la razón por la que el Estatuto de Autonomía del artículo 151 CE únicamente puede ser el resultado de un pacto de naturaleza política del que únicamente pueden ser portadores órganos constitucionales legitimados democráticamente de manera directa, las Cortes Generales, el Parlamento y el cuerpo electoral de la nacionalidad o región. Y esta es la razón también por la que un pacto de esta naturaleza no puede ser sometido al control de un Tribunal Constitucional que carece de dicha legitimación directa.

El pacto político, el pacto de inserción de la nacionalidad o región en el Estado, es la esencia del Estatuto de Autonomía del artículo 151 CE. Se trata necesariamente de un pacto global, en el que tanto las Cortes Generales como el Parlamento de la nacionalidad o región han consentido que unos artículos queden redactados de una forma a cambio de que otros queden redactados de otra manera. Y sobre ese pacto global es sobre el que se ha pedido a los ciudadanos que se pronuncien en referéndum, es decir, emitiendo un juicio global.

El control de un Tribunal Constitucional es, por definición, un control particular, de artículos o de apartados o incluso incisos de determinados apartados de determinados artículos. Un control de este tipo desnaturaliza el pacto alcanzado a tres bandas entre las Cortes, el Parlamento autonómico y el cuerpo electoral de la nacionalidad o región afectada.

Dicho de otra manera: el Tribunal Constitucional no debería haber tenido que pronunciarse en un recurso de inconstitucionalidad contra la reforma del Estatuto de Autonomía para Cataluña. Reforma estatutaria y control de constitucionalidad por el Tribunal Constitucional son términos excluyentes. El control de constitucionalidad del ejercicio del derecho a la autonomía lo hacen las Cortes Generales y nada más que ellas. La intervención de cualquier otro órgano conduce inevitablemente al disparate. Es lo que ha ocurrido.

\section{RAMÓN PUNSET BlanCO}

Resulta indudable que el TC fue sometido a una prueba muy dura con ocasión de los recursos de inconstitucionalidad formulados contra la Ley Orgánica 6/2006, de 19 de julio, de reforma del Estatuto de Autonomía de Cataluña. El primero de tales recursos (y el más importante por el considerable número de los preceptos impugnados), interpuesto por el Grupo Parlamentario Popular del Congreso el 31 de julio siguiente, se resolvió casi cuatro años después (STC 31/2010, de 28 de junio). Durante este largo período, en el que se sucedieron tres ponentes y se acordó un método de votación separada por bloques para facilitar la adopción de los distintos pronunciamientos de la sentencia, la tensión institucional, política y mediática que hubo de soportar el Tribunal fue altísima. Primero en el plano procesal. Los actores recusaron desde el principio al Magistrado Pérez Tremps, siendo estimada la recusación con cinco votos particulares discrepantes. Meses después recusaron también a la Presidenta Casas Baamonde, resultando su pretensión inadmitida, 
como lo fueron también las recusaciones de los Magistrados García-Calvo y RodríguezZapata formuladas por La Generalidad y el Parlamento autonómico. El 26 de mayo de 2010, el Gobierno de la Comunidad Autónoma, entendiendo que el Tribunal (con cuatro de sus miembros en situación de mandato caducado desde hacía más de dos años y cinco meses y la vacante producida por el fallecimiento del Magistrado García-Calvo el 17 de mayo de 2008, a la sazón, y todavía hoy, sin cubrir) no reunía las condiciones exigidas por la Constitución para ejercer sus funciones jurisdiccionales, instó su abstención o inhibición, pretendiendo que acordara declinar la competencia para resolver el recurso, debiendo abstenerse de participar en la deliberación de tal solicitud los Magistrados en prórroga. De forma similar se manifestó el Parlamento de Cataluña mediante escrito del día 27 de mayo. Ambas pretensiones fueron denegadas. Todavía en fecha tan tardía como el 10 de junio de 2010 intentó el Ejecutivo catalán, nuevamente sin éxito, que la recusación del Magistrado Pérez Tremps se ciñera a unos pocos preceptos, lo que le permitiría participar en la votación de los restantes. En mi opinión, todas estas cuestiones procesales resultaron correctamente solventadas por el TC, oponiendo la fuerza del Derecho a los burdos intentos de manipulación y deslegitimación. Es obvio que, por imperativo legal (art. 17.2 LOTC), los Magistrados del Tribunal Constitucional han de continuar «en el ejercicio de sus funciones hasta que hayan tomado posesión quienes hubieren de sucederles», y que tal continuidad se produce en plenitud de ejercicio del cargo, sin merma alguna de su capacidad de integrar los órganos del Tribunal y de actuar en ellos sin restricción derivada de la prórroga. La figura del Magistrado en funciones torpe imitación de la del Gobierno en funciones- es de imposible existencia en un órgano jurisdiccional. No obstante su origen electivo, el TC no es un órgano representativo, sino que se le declara legalmente «independiente de los demás órganos constitucionales» (art. 1.1 LOTC), de forma coherente con su carácter de «intérprete supremo de la Constitución» (ibídem). La «legitimidad» de los Magistrados coincide por completo, pues, con las previsiones legales que regulan su situación (véanse también al respecto los arts. 23 y 24 LOTC). Sin duda, ha de considerarse no sólo lamentable, sino manifestación palmaria de deslealtad constitucional, la no renovación en plazo de los Magistrados del TC, pero ello en nada afecta a la plenitud funcional de aquellos que, ex lege, continúan desempeñando el cargo más allá del término del mandato para el que fueron designados.

Hubo también intentos de deslegitimación del Tribunal en los medios de comunicación, en las declaraciones altisonantes de las instituciones catalanas (incluidas algunas de desafío por parte del Presidente de la Generalidad incompatibles con el Estado de Derecho) y en los juristas cercanos al catalanismo y al socialismo. El Tribunal Constitucional, se sostuvo machaconamente, carecía de legitimidad — y menos aún un Tribunal no renovado- para enjuiciar un texto ratificado en referéndum por el pueblo catalán y expresivo de un pacto político entre Cataluña y España. Eso no podía tolerarlo «la dignidad de Catalunya», según rezaba en su título un editorial colectivo de la prensa catalana, respaldado por una declaración institucional del Parlamento autonómico. Todos estos argumentos ideológicos, también voceados por eminentes iuspublicistas sin capacidad de sonrojo, se dirigían a la intoxicación de la opinión pública e ignoraban deliberadamente las previsiones de la LOTC, según la cual «son susceptibles de declaración de inconstitucionalidad... los Estatutos de Autonomía y las demás Leyes orgánicas» (art. 27.2 a]). 
No creo que valga ya la pena detenerse en semejante argumentario, habida cuenta de la doctrina de la STC 31/2010 sobre la posición de los Estatutos en el ordenamiento jurídico y su relación con la supremacía constitucional. Únicamente cabe ahora dejar constancia de que, en su largo y accidentado caminar hacia el pronunciamiento de dicha Sentencia, el Tribunal dio un alarmante signo de desfallecimiento y desorientación al resolver el recurso de inconstitucionalidad interpuesto contra un determinado precepto de la Ley Orgánica 1/2006, de 10 de abril, de reforma del Estatuto de Autonomía de la Comunidad Valenciana.

La STC 247/2007 fue, en efecto, una demostración patética de la aporía histórica por la que estaba atravesando el Tribunal y una resolución sumamente desafortunada en el tratamiento de todos los asuntos abordados. En uno de ellos el Tribunal quiso hacer innecesariamente, por otra parte- la sistematización completa de la doctrina jurisprudencial relativa a la posición de los Estatutos de Autonomía en el sistema de fuentes. El resultado del intento generó, sin embargo, una confusión considerable, que hacía temer un caos conceptual en pronunciamientos posteriores de mayor trascendencia, como el que aguardaba a propósito del Estatuto catalán. Tras la STC 247/2007 la propia doctrina científica se enzarzó en debates que revelaban la falta de claridad de los postulados del Tribunal como consecuencia de las presiones políticas que se hallaba padeciendo: tal sucedió con la disputa acerca de si el TC, en la Sentencia citada, partía de la tesis de la desconstitucionalización del Estado autonómico para otorgar a los Estatutos la posibilidad de definir, cada uno de ellos, el alcance de las competencias estatales; o acerca de la posibilidad, que el TC admitía, de que un Estatuto que invadiera o contraviniese el ámbito material constitucionalmente reservado a una ley orgánica no resultara inválido sino meramente ineficaz, a criterio del propio Tribunal. Afortunadamente, la STC 31/2010 hizo devenir episódico un razonamiento que hubiera alterado, de consolidarse, la misma forma estatal.

¿Salió finalmente airoso el TC de la ordalía que supuso el enjuiciamiento del Estatuto de Cataluña? La división del Tribunal y la consiguiente abundancia de votos particulares discrepantes deben considerarse como un hecho normal. Sólo a los legos en Derecho puede escandalizar la existencia de dissenting opinions en el ejercicio de la función jurisdiccional, especialmente en el marco de la justicia constitucional, dada la estructura característica de las normas de la Constitución. La mayor proximidad de los jueces constitucionales a las fuerzas políticas que propiciaron su designación resulta, por supuesto, y en términos generales, un hecho evidente, si bien las etiquetas de "progresistas» $\mathrm{y}$ «conservadores» me parecen totalmente inadecuadas: un Magistrado del TC ha de hallarse al servicio exclusivo de la «conservación» de la Constitución, que sólo al poder constituyente constituido, y no al legislador ordinario, le es lícito modificar. La respuesta a nuestro interrogante ha de venir, pues, de la mayor o menor calidad de la Sentencia dictada, considerada desde tal perspectiva. Una Sentencia que, habida cuenta de la amplitud de la impugnación, se ha convertido en un tratado sobre la forma territorial del Estado español, la cual, en fin —y he aquí, a mi juicio, lo decisivo—, ha resultado, si no reforzada, sí al menos preservada por la dificultosa resolución del Tribunal Constitucional. Vistas las circunstancias, seguramente no cabía pedir más. Ahora conviene que quienes pretendan otra cosa planteen abiertamente la reforma constitucional. No es la Constitución la que ha de acomodarse a los Estatutos de Autonomía, sino éstos a aquélla. 


\section{Juan Alfonso Santamaría Pastor}

El deterioro del prestigio del Tribunal Constitucional en la opinión pública es tan lamentable como indiscutible; y sus causas, a mi entender, son abundantes, diversas y complejas. Una exposición sintética de las mismas (la única que cabe en una encuesta de esta naturaleza) ofrece grandes riesgos de ser malinterpretada en muchos de sus aspectos y, lo que es peor, de herir susceptibilidades por la obligada ausencia de matices y salvedades. Trataré de exponer algunas de ellas, distinguiendo las que afectan a la — por así decir — generalidad de la población (1, 2 y 3) de las que son sólo perceptibles por la comunidad jurídica (4 a 8).

1) Comenzando por las que sugiere el cuestionario, no creo que las recusaciones que se han producido en los últimos años hayan tenido una influencia relevante. Con independencia de su solidez intrínseca, que en ningún caso me ha parecido excesiva, creo que las recusaciones han sido más bien un instrumento táctico empleado por litigantes ante el Tribunal, aprovechando la imagen de politización partidaria que se ha vertido sobre diversos miembros de éste; no han añadido nada a la creencia general de la actuación políticamente sesgada de determinados miembros del Tribunal, sino sólo formalizar una generalizada desconfianza en la objetividad de los mismos.

2) Tampoco doy relevancia especial a la insólita tardanza en la cobertura de las vacantes, que es una disfunción propia de los partidos políticos, no del Tribunal ni de los miembros finalmente elegidos. Tal tardanza es sólo un factor que ha contribuido a la imagen de politización del Tribunal y de los finalmente nombrados; pero en sí misma es un fenómeno neutro.

3) La «imagen de politización» a que vengo aludiendo ha sido, a mi juicio, el factor capital de desprestigio del Tribunal, creando una apariencia de sumisión estricta a los dictados de los grupos políticos proponentes de cada uno de los Magistrados. Tal apariencia ha respondido pocas veces a la realidad, y estoy convencido, por conocer a muchos de ellos personalmente, que la inmensa mayoría de los Magistrados goza y ha gozado de un nivel de independencia subjetiva muy acusado, sin perjuicio de su ideología personal; de hecho, han sido muy numerosos los que han sido nombrados por consenso de los dos grandes partidos nacionales, aunque después los medios los encasillaran en una u otra tendencia política (muchas veces, con manifiesto error, por cierto). Pero tampoco puede ocultarse que esta imagen ha podido pesar, en algunas ocasiones, en el comportamiento de algunos de ellos, llevándoles inconscientemente a actuar en la línea que públicamente se esperaba de ellos.

4) La percepción que la comunidad jurídica tiene del Tribunal ha experimentado un giro importante. El primer Tribunal, integrado por personas de reputación científica o profesional indiscutible y de una probada independencia de criterio, gozó de un considerable prestigio (no sólo atribuible a la novedad de la institución), que se ha ido diluyendo con el tiempo. Y ello ha tenido que ver, desde luego, con la disminución del nivel y prestigio profesional de algunos de los Magistrados elegidos. Tras las primeras renovaciones, el nivel de exigencia impuesto por los partidos a sus candidatos bajó de modo sensible, nombrándose a algunas personas que, aparte de su no cuestionada valía, resultaban desconocidas fuera de muy pequeños círculos profesionales. Siempre ha habido y hay juristas de primera línea en el Tribunal, por fortuna, pero acompañados de otros de mucho menor porte; todos ellos, los primeros y los segundos, han realizado una labor importante y de calidad en el Tribunal, y 
su competencia técnica no se discute. Pero la creciente aparición de Magistrados poco menos que inéditos ha difundido la impresión de que cualquier jurista mediano podía acceder al cargo si disponía de los apoyos políticos necesarios. La impresión es, probablemente, errónea e injusta; pero su difusión es innegable.

5) Otro factor que impactó fuertemente en la opinión de la comunidad jurídica española fue el posterior acceso de algunos Magistrados, tras la expiración de su mandato, a puestos o cargos de libre designación gubernamental (o, al menos, la perspectiva de que sucediera así). En varias ocasiones me he visto forzado a discutir con compañeros de profesión que los nombramientos que se habían efectuado de algunos ex Magistrados estaban absolutamente justificados, y que no podían explicarse, en modo alguno, como un premio a su fidelidad a directrices políticas de uno u otro signo. Pero es indiscutible que el mero hecho de que un Magistrado pueda, después de su cese, ascender de forma no ordinaria en su carrera o ser designado para cargos de responsabilidad, no hace ningún favor a la imagen de imparcialidad que debe ofrecer, y contamina a todo el Tribunal; también, lo que es más injusto aún, a algunos de los que no obtienen «premio» alguno (porque no lo piden ni lo necesitan), que quedan marcados como rebeldes frente a la línea oficial y encasillados en el partido de la oposición.

Esta cuestión, tan delicada como trascendental, merecería una reflexión colectiva en profundidad acerca de la duración deseable del mandato de los miembros del Tribunal, de la edad mínima para acceder al cargo y de la prohibición de ostentar cargos electos o altos cargos en sentido técnico durante un prolongado período posterior a su cese como Magistrados. Pero todo ello, por su complejidad, no puede ser tratado en el marco de esta encuesta.

6) Tampoco ha contribuido al prestigio del Tribunal (entre los segmentos más cualificados del mundo jurídico) el excesivo nivel de self restraint de que el Tribunal ha hecho gala en casi toda su historia, con abuso notorio de las sentencias interpretativas y manipulativas. Por comprensible que sea en el plano personal, el argumento contramayoritario ha pesado en forma superior lo deseable sobre los sucesivos Tribunales, permitiendo y propiciando los desafueros de los legisladores. El que el peso de la doctrina del Tribunal recaiga en los fundamentos jurídicos de sus sentencias, y la búsqueda de soluciones creativas posibilistas ha generado una imagen no injustificada de falta de rigor y compromiso con los valores constitucionales, y de temor reverencial hacia los gobiernos de turno; además de un factor adicional de extrema complejidad en la interpretación constitucional. Guste o no, el Tribunal Constitucional es un legislador negativo, y desde luego no se ha comportado con la autoridad y contundencia que hubiera sido deseable en muchas ocasiones.

7) Es inevitable aludir a la extraordinaria demora en los fallos del Tribunal, a la que, como tantos otros, ya he tenido que referirme en algún otro lugar. La demora es tan indeseable como justificada por el elevadísimo número de recursos de amparo planteados al Tribunal. Pero esta disfunción, aparte de sus efectos naturales sobre la eficacia de los fallos, ha permitido la difusión de insinuaciones maliciosas acerca de la supuesta pereza de los Magistrados, basadas en cálculos comparativos de producción de sentencias de una simplicidad tan vergonzosa como eficaz. La que expreso es imaginaria, pero bien podría haber sido una de ellas: ¿cómo es posible que la Sala primera del Tribunal Supremo, compuesta por doce Magistrados, haya podido dictar, en 2009, 829 Sentencias, en tanto que el Tribunal Constitucional, con el mismo número de miembros sólo dictara en el mismo período 220? 
Huelga decir que estas insinuaciones no deberían merecer crédito alguno: nadie que conozca mínimamente el régimen de trabajo del Tribunal puede sostener sin cinismo una imputación de molicie a sus miembros y a todo el personal a su servicio. Pero es evidente que han surtido efecto, coadyuvando al fenómeno de pérdida de prestigio de la justicia constitucional.

8) Finalmente, cabe aludir a la puesta en práctica (por el Tribunal con el apoyo del legislador) de medios dirigidos a resolver el problema de la demora; medios que hasta ahora no se han mostrado eficaces (esperemos que lo sean en breve plazo) pero que, además, y en mi modesta opinión, se vienen utilizando con escasa fortuna, contribuyendo a una nada halagüeña apariencia de arbitrariedad.

Me refiero, claro está, a la sistemática inadmisión de los recursos de amparo mediante el empleo del requisito de la «especial trascendencia constitucional» que la Ley Orgánica 6/2007, de 24 de mayo introdujo como artículo 50.1.b) de la LOTC. Por duro que sea para muchos recurrentes y sus respectivos abogados (entre los que me cuento), no hay otra fórmula hábil para la descongestión del Tribunal que esta modalidad de certiorari (salvo la alguna vez sugerida de la creación de un segundo Tribunal, aunque fuera sólo para los amparos planteados con fundamento en el polémico artículo 24, que quizá no sea disparatada: ahí está el ejemplo de la Unión Europea), que siempre he defendido en el plano académico. El problema está en que la lectura asidua de la jurisprudencia del Tribunal muestra aún multitud de sentencias cuya relevancia constitucional parece mínima o nula, pero que sorprendentemente pasaron este riguroso filtro de admisión; sentencias que recogen doctrina reiterada ad nauseam y que no aportan novedad alguna, por importantes que sean para las partes. Es cierto que estas sentencias provienen, al menos en buena parte, de recursos interpuestos antes de la entrada en vigor de la Ley 6/2007 (no he hecho una comprobación exhaustiva); el riesgo es que esta línea se prolongue por inercia, y que junto a la selección de casos realmente relevantes se tienda a fallar otros muchos repetitivos, que sirvan para completar un volumen anual de sentencias que no sea susceptible de una crítica fácil e insolvente en los medios. Confío en que esta tentación se conjure: todos los juristas prácticos apreciaríamos sobremanera que la colección anual de sentencias del Tribunal se redujera a no más de cincuenta fallos de interés decisivo; y también, por volver sobre alguna cuestión ya aludida antes, mucho más expeditivas y contundentes.

2. Transcurridos más de treinta años de vigencia de nuestra Constitución, ila composición que para el TC prevé el art. 159 le parece óptima o sugeriría alguna propuesta de constitutione ferenda? Y en la medida en que está en vigor el apartado 2 de tal precepto ¿entiende que el requisito de la reconocida competencia de todos los magistrados se limita a que cuenten con más de quince años de ejercicio profesional o debe conllevar un plus?

\section{Luis Aguiar De LUQUE}

La composición del Tribunal Constitucional en nuestro ordenamiento constitucional viene contemplada por el art. 159 del texto constitucional, precepto que, al margen de fijar el número de miembros que lo integran y la duración del mandato en nueve 
años, a) establece las líneas básicas del procedimiento de nombramiento de los magistrados constitucionales (órganos que intervienen decisivamente en la selección de los miembros del Tribunal y mayorías requeridas para realizar los nombramientos) y b) señala una especie de prerrequisitos para poder ser nombrado miembro de dicho órgano.

A. En lo que se refiere al primero de los aspectos indicados, el constituyente ha seguido el criterio que viene siendo tónica habitual en el derecho comparado ulterior a la II Guerra Mundial para este tipo de órganos (criterio, por lo demás, que en buena medida coincide con el preconizado por H. Kelsen en su clásico trabajo en la Revue de Droit Public de 1927): configurar un origen plural de los magistrados constitucionales en el que participan los diversos órganos constitucionales que materializan los tres poderes clásicos del Estado (legislativo, ejecutivo y judicial), pero con predominio de los de extracción parlamentaria (véase «Modelos de renovación personal de Tribunales Constitucionales» en Revista Española de Derecho Constitucional, núm. 61, 2001) y exigencia de una mayoría en tales órganos de tres quintos (con la obvia salvedad del Gobierno y extendida por el legislador orgánico también a los propuestos por el CGPJ) para poder formular la propuesta de nombramiento.

Este origen diversificado y plural de los magistrados constitucionales, unido a la exigencia de unas mayorías cualificadas notablemente altas que propicien consensos que trasciendan a mayorías políticas coyunturales, persigue dotar al Tribunal de una posición equidistante respecto a los restantes órganos constitucionales y favorecer el distanciamiento entre las instancias dominantemente políticas que intervienen en designación de los magistrados constitucionales y la labor que cotidianamente estos desempeñan.

En suma, sin entrar ahora en las modificaciones introducidas por la reforma de la LOTC en lo tocante a las propuestas de nombramientos que corresponden al Senado, creo que ningún reparo se puede oponer a las líneas generales que el constituyente estableciera para el nombramiento de magistrados constitucionales.

Lo anterior, sin embargo, no empece para constatar que los resultados alcanzados con ese diseño constitucional no han sido siempre enteramente satisfactorios, pudiendo afirmarse que en determinadas ocasiones la puesta en práctica de la regulación constitucional y legal ha llegado a provocar más disfunciones de las deseables y algunas particularmente graves.

No es este momento ni lugar adecuado para realizar una valoración de los nombramientos realizados en los treinta años de funcionamiento del Tribunal Constitucional. Sería, amén de osado, de todo punto improcedente.

Lo anterior, no obstante, no debe ser obstáculo para señalar una vez más el dato constatado en reiteradas ocasiones en sede doctrinal acerca de la altísima cualificación jurídica del primer Tribunal, integrado en buena medida por los principales «caposcuola» de las diferentes disciplinas jurídicas.

Como tampoco puede dejarse de aludir a la evolución que se ha producido en aquellos nombramientos de origen parlamentario en cuanto al modo de alcanzarse los compromisos entre las dos principales fuerzas políticas del arco parlamentario conducentes a lograr el respaldo de las mayorías cualificadas exigidas por la Constitución. Mientras que en los primeros años el acuerdo parecía alcanzarse sobre la base de un pleno y trabado acuerdo sobre cada uno de los candidatos comprendidos en la propuesta, en las ulteriores ocasiones parece haberse ido avanzando en el sentido de una mayor «lottiz- 
zazione» de la propuesta, dotando de una mayor rigidez a las cuotas respaldadas por cada uno de los dos principales partidos. Dicha rigidez parece haber alcanzado un grado máximo con la actitud - al parecer- de los representantes del Partido Popular en la negociación en curso en el momento de escribir estas líneas (julio 2011) para formalizar la propuesta de renovación que corresponde realizar al Congreso de los Diputados, al oponerse aquellos a que cualquiera de los candidatos propuestos por dicho grupo parlamentario pudiera ser vetado.

Evidentemente el método histórico de interpretación constitucional debe integrarse con otros posibles criterios hermenéuticos. Pero desde aquella específica perspectiva, me parece incuestionable que cuando nuestro constituyente estableció la cualificada mayoría de tres quintos para formulación de propuestas parlamentarias de nombramiento de magistrados constitucionales, latía en dicha regulación la pretensión de que tales propuestas se realizasen por «consenso», esto es, que las propuestas de nombramiento que se elevasen al Rey, aunque no satisficieran plenamente a todos, tampoco les disgustara a ninguno del todo (tomo prestada la idea de M. Duverger citado por O. Alzaga en su excelente Discurso de Ingreso en la Real Academia de Ciencia Morales y Políticas sobre «El consenso. Del proceso constituyente a las prácticas postconstitucionales»). O dicho en otros términos, un rígido entendimiento del proceso antes citado de «lottizzazione», está más alejado del ideal constituyente que un proceso en el que una de las partes goza de un moderado derecho de vetar a alguno de los candidatos propuestos por alguno de los restantes negociadores.

El resultado de esta rigidez de la «lottizzazione» o, en sentido negativo, la reiterada y firme oposición de uno de los partidos imprescindibles para alcanzar las mayorías parlamentarias exigidas por la Constitución de acceder al acuerdo cuando se veta a uno de sus candidatos ha ocasionado la que probablemente sea la mayor disfunción producida en materia de nombramiento de magistrados constitucionales, le desorbitada demora de las dos últimas renovaciones que tanto están desgastando el prestigio (y en cierta medida la legitimidad) del Tribunal Constitucional. Pero en la medida en que dicha cuestión es objeto de otra de las preguntas de la presente Encuesta, dejo para más adelante abordar dicho problema.

\section{Francisco Javier Díez Revorio}

Creo que de mi anterior respuesta puede deducirse que, en mi modesta opinión, la composición constitucionalmente prevista del Tribunal, o los requisitos exigidos para ser propuesto magistrado, no son las causas principales de la profunda crisis de imagen por la que atraviesa el Tribunal, dado que con la misma regulación ha pasado por momentos mejores. Por un lado, la composición, con ciertas variantes, no difiere demasiado de la de otros Tribunales Constitucionales europeos o americanos. Por otro, creo que se puede afirmar sin lugar a dudas la suficiencia de la preparación y competencia jurídica de todos los magistrados del Tribunal. La clave de los problemas del Tribunal está en la falta de responsabilidad y de respeto demostrada (aunque no se pueda generalizar) por algunos sujetos políticos, sociales e institucionales. Por ello creo que los cambios fundamentales que requiere el Tribunal Constitucional difícilmente se lograrán con una mera modificación 
normativa, si esta no va acompañada de la superación de ciertas actitudes indeseables; y seguramente van a requerir — si se logran — cierto tiempo para implantarse.

Por lo demás, los cambios que sugiere la pregunta requerirían una reforma de la Constitución, hipótesis que en este momento resulta casi inverosímil por factores de tipo político, y por tanto cualquier propuesta en esta línea debe ser consciente de que su viabilidad solo existiría, tal vez, en un medio plazo.

Dicho lo anterior, el Derecho Comparado y la doctrina constitucional nos ofrecen otras alternativas de regulación que pueden resultar interesantes y dignas de consideración, e incluso en algunos casos podrían mejorar algunos aspectos de la composición y funcionamiento de nuestro Tribunal Constitucional. No es posible llevar a cabo aquí un inventario de propuestas, y menos analizar cada una de ellas con cierto detalle. Pero al menos podemos mencionar algunas que en algún momento sería positivo considerar. Por ejemplo, la elección de un número de magistrados impar, que evite en lo posible los empates en el Pleno en asuntos de gran trascendencia política (nueve o quince magistrados podrían ser un buen número). $\mathrm{O}$ acaso disminuir la dependencia parlamentaria equilibrando la participación de los distintos poderes en la elección de magistrados, como sucede en algunos sistemas comparados —aunque ciertamente en otros el protagonismo parlamentario en el nombramiento es total—. Incluso parece digna de consideración la propuesta de disminuir los riesgos de dependencia política dotando a los magistrados de una mayor estabilidad en el cargo, tal vez con un nombramiento vitalicio como sucede en el Tribunal Supremo norteamericano, o hasta la jubilación como sucede en otros tribunales (incluyendo a nuestro Tribunal Supremo), aunque también habría que analizar otros riesgos de esta propuesta, como el consiguiente «envejecimiento» de los magistrados del Tribunal.

En cuanto al requisito de que los magistrados sean «juristas de reconocida competencia con más de quince años de ejercicio profesional», ciertamente parece difícil objetivar la primera parte del inciso. Y si bien la preparación jurídica suficiente de los magistrados parece haberse logrado en general con esta regulación, acaso cabría buscar una mayor garantía de la experiencia profesional aumentando el requisito cuantitativo establecido en la segunda parte del mismo. Aunque no estoy totalmente seguro de ello, tal vez este aumento redundaría también en un menor riesgo de que un magistrado pueda «estar pendiente» de un futuro cargo de designación política tras abandonar el Tribunal, toda vez que saldría de este en una edad más próxima a la jubilación...

\section{Alfonso Fernández Miranda}

1. Ante todo quisiera manifestar un cierto escepticismo sobre la capacidad del Derecho, por si sólo, para modificar comportamientos. Entiendo que el problema, más que de regulación formal, es de «sistema» (léase "partidocracia») y de hábitos y cultura democráticos. Piénsese, como ejemplo elocuente, que el nacimiento de la «moderna» independencia judicial frente al poder político tiene su cuna, como tantas otras cosas, en Inglaterra en el contexto de las guerras civiles del siglo XVII en las que junto a la lucha Parlamento-Corona, se desarrolla otra entre los tribunales del Common Law, aliados con el Parlamento, y los tribunales de Prerrogativa, al servicio de la Corona. 
Lo que quiero poner de relieve es que Inglaterra no ha necesitado, en este campo, de complejos y sutiles mecanismos formales para garantizar una asentada y sólida independencia judicial, pese a que los jueces británicos son de nombramiento gubernamental. Es verdad que, entre otros, los jueces-lores son nombrados con carácter vitalicio lo que, sin duda, es una fuente de independencia, pero, con todo, lo más importante es la fuerte tradición cultural que determina, entre otras cosas, que no haya una tenaz voluntad "partidocrática» de apoderarse de las instituciones judiciales y del ministerio fiscal como ocurre en España. Lo decisivo, servido por una tradición arraigada, son una cultura y unos hábitos de profundo respeto a la independencia judicial.

Desde este escepticismo pesimista voy a hacer algunas reflexiones. En primer lugar parece claro que no hay un «sistema ideal», que todos tienen sus ventajas y sus inconvenientes que será preciso ponderar. En Europa, donde ha triunfado masivamente la jurisdicción concentrada, también predomina el mandato limitado, la renovación parcial y la elección por órganos representativos. Personalmente, el sistema diseñado por la Constitución española no me parece peor que otros y lo estimo, en teoría, razonable. Otra cosa es que haya sido aplicado, a partir de un cierto momento, con criterios y prácticas lamentables.

El que los miembros del Tribunal sean seleccionados por órganos representativos y plurales (frente a, por ejemplo, el sistema estadounidense en donde, aunque con la necesidad del consentimiento del Senado — que no deja de tener una enorme relevancia práctica- el nombramiento, es competencia del Presidente) tiene ventajas en términos de legitimación. Es bueno para la propia legitimación democrática del Tribunal que en él se proyecten las diversas sensibilidades jurídicas que nunca son irrelevantes en el proceso de interpretación y aplicación del Derecho. También tiene sus ventajas teóricas la renovación temporal y parcial, porque permite mantener ese flujo de legitimación que de alguna manera aproxima a los jueces sucesivos a la cambiante sensibilidad social y al evolucionar de la percepción de los valores en la sociedad.

Aunque la mayoría de los países europeos han optado por un sistema de mandato limitados no faltan ejemplos (Luxemburgo, Bélgica o Austria) de otros que han preferido un mandato hasta la edad de jubilación (sin mencionar los que dotan al mandato de carácter vitalicio). De nuevo hay que señalar que este tipo de mandato también tiene sus ventajas y sus inconvenientes que son, a su vez, el contrapunto de las que tiene el mandato limitado. Así, como se ha dicho muchas veces, el mandato vitalicio, o hasta la jubilación, alivia el riesgo para la independencia de promesas futuras de los partidos políticos o de expectativas de futuro de un juez joven que culminaría su mandato con una importante perspectiva de futuro en activo. Claro que el riesgo que no alivia es el del ofrecimiento del cargo en pago a los servicios prestados.

También parece claro que este tipo de mandato evita las renovaciones periódicas a plazo fijo y puede dificultar o hacer imposible el sistema de «cuotas» porque lo normal es que las renovaciones sean una a una, de suerte (otra teórica ventaja) que en esa elección individual se incrementara la atención sobre el candidato único y se hiciera más exigente el cumplimiento del requisito de la «reconocida competencia». No obstante, creo que en el debe de este modelo habría que situar un potencial déficit de legitimación democrática, sobre todo, si como ha sucedido entre nosotros varias veces, se designa a 
miembros muy jóvenes con cuarenta años o más de vida laboral activa por delante. En estos casos estaría, quizás, mejor garantizada la independencia, pero no una sensibilidad jurídica ni una percepción de los valores en conexión con la realidad social.

En cualquier caso, se mantenga o se cambie el actual sistema, no debería desconsiderarse la capacidad que tiene la partidocracia a la que hemos llegado, de corromperlo todo.

No voy a extenderme sobre otros modelos extra-europeos como el modelo canadiense, en el que el Parlamento puede llegar a hace prevalecer su opinión sobre el criterio judicial. El modelo me parece inadecuado para nuestro país, en primer lugar porque no tiene fácil encaje en el concepto dominante en Europa (y en los Estados Unidos) de Constitución normativa y de radical protección de los derechos de las minorías. (En algún sentido este sistema trasluce, pese a ser un país de Constitución escrita, la poderosa influencia británica y su particular comprensión de la posición del Parlamento en el sistema). En segundo lugar obligaría a una reforma constitucional de extraordinario calado que difícilmente encontraría consenso. Y en tercer lugar, y sobre todo, porque no confío en absoluto del uso que harían de tal sistema nuestros partidos políticos y sus circunstanciales mayorías parlamentarias. La experiencia sobre sus discrepancias en materia de constitucionalidad y la relativa facilidad con que prometen cambiar las normas «del Otro» cuando alcancen el poder, es, según creo, argumento sobrado para recelar de tal sistema. La experiencia debería servir, al menos, para aprender.

No quisiera concluir sin hacer referencia a una propuesta que no ha dejado de estar presente en la recurrente polémica sobre el Tribunal Constitucional. Hablo de quienes han postulado la supresión del Tribunal Constitucional. No me refiero ahora a las posiciones muy minoritarias que, desde una comprensión «jacobina» de la soberanía del Parlamento y de la incontrolabilidad de la voluntad de la mayoría, esto es, de la voluntad del legislador democrático, abominan de la justicia constitucional, al menos en lo que tiene de control de la constitucionalidad de las leyes. No. Me refiero a quienes aceptan esa limitación, a quienes considerando al Parlamento un poder constituido sujeto a la Constitución, no ven la necesidad de un Tribunal Constitucional específico y sostienen la conveniencia de atribuir sus competencias al Poder Judicial ordinario, ya sea en un sistema de jurisdicción difusa, de jurisdicción mixta o, en la mayoría de los casos, de jurisdicción concentrada pero con la competencia atribuida al Tribunal Supremo.

Me parece una propuesta tan defendible teóricamente como políticamente inviable porque, entre otras cosas, confronta con una tradición europeo-continental fuertemente arraigada, con profundas raíces históricas y no ayuna de serios argumentos justificativos en la actualidad.

Todas las luminosas reflexiones de Kelsen en favor de los Tribunales constitucionales y de la jurisdicción concentrada, son, según creo, sólidos argumentos, al servicio de la seguridad jurídica y de la legitimación democrática, para justificar el sistema; pero no explican su génesis. Se trata de una justificación lógica, jurídica y política, pero no de una explicación histórica del fracaso en Europa del control de constitucionalidad .

Ésta, a mi parecer, se encuentra en una profunda desconfianza hacia los jueces que se gesta en los procesos revolucionarios europeos. Recuerdo que en mi primera juventud, leyendo la monumental Historia de la Revolución Francesa de Jules Michelet, me llamó la 
atención, y me desconcertó, una frase del autor (que no es un mero historiador distanciado de su objeto de conocimiento sino, además y sobre todo, un implicado y apasionado defensor del proceso revolucionario). Afirmaba Michelet que «nuestro gran enemigo (el gran enemigo de la Revolución) eran los jueces».

Cuando años después leí los discursos pronunciados por los revolucionarios franceses desde «la tribune de la Chambre», creí entenderlo al «escuchar» a Robespierre defendiendo la «inviolabilité (inmunidad en España) parlamentaire « «¿Quiénes son esos señores (los jueces) para oponerse a la voluntad de la Nación aquí representada, o para detener y procesar a sus miembros?». Creí entender entonces el principio de radical sumisión «al imperio de la Ley» del juez continental frente a la tradición anglosajona. Y creí entender el origen y el sentido de instituciones francesas, aún hoy día desconocidas en las países de tradición anglosajona, como la inmunidad parlamentaria.

El juez anglosajón no fué un enemigo de la revolución liberal. En Inglaterra, ya desde el siglo XVII, los jueces del Common Law son aliados del Parlamento frente a la Corona y sus tribunales de Prerrogativa También en los Estados Unidos, unos jueces en gran parte formados bajo la cultura británica en la época colonial estarán comprometidos, en su inmensa mayoría, con la causa de la independencia y de la revolución liberal-democrática. No hay motivos para recelar de un sistema judicial con prestigioso arraigo en la sociedad emergente. Muy al contrario, en los procesos revolucionarios europeo-continentales, primero en 'Francia, después en España o en Italia... los jueces son funcionarios de la Corona, o miembros del peculiar «Parlamento» francés, en todo caso al servicio de la causa legitimista, es decir, en guerra civil, larvada o explícita, contra las fuerzas revolucionarias. Resultaba imposible atribuirles nada menos que la competencia de controlar la voluntad del Parlamento. Al revés, es el Parlamento el que tiene una enérgica voluntad de controlar la acción de los jueces.

No debo extenderme más en estas respuestas, pero esta desconfianza hacia los jueces, esa tradición de sumisión del aparato judicial «al imperio de la Ley», es decir, a la voluntad de la mayoría parlamentaria, que hace a Sieyés buscar una garantía de la supremacía constitucional mediante el control por órganos de naturaleza política, y que hace que Francia se convierta durante mucho tiempo, en los mejores períodos, en un Estado de legalidad y no de constitucionalidad, pervive hasta nuestros días.

Pervive cuando se diseña el sistema de control en la vigente Constitución italiana o en la Ley Fundamental de Bonn; pervive en la conciencia de los constituyentes franceses cuando elaboran la Constitución de 1958, y está presente en el proceso constituyente español. Al cabo, los miembros de la judicatura que ejercían su potetad el día antes de la muerte de Franco, eran los mismos que la ejercían al día siguiente y, sustancialmente, los mismos que lo hacían el día después de la aprobación de la vigente Constitución democrática.

Quebrar esta tradición continental de sumisión del Poder judicial al imperio de la Ley me parece una tarea prácticamente imposible y teóricamente cuestionable. Sobre todo por un problema, no de legitimidad sino de legitimación democrática. Los funcionarios judiciales, Jueces o Magistrados (excelentes profesionales en su mayoría), no son en absoluto representativos de la sociedad. Y no hablo, como es obvio, de representatividad política, sino de una cierta representatividad de las diversas sensibilidades jurídicas que no están en modo alguno desvinculadas de las diversas posiciones idelógicas y la variada 
percepción histórica de los valores. Sería extremadamente difícil que la izquierda europea en general, y la española en particular, aceptasen la quiebra del principio de sumisión a la Ley. Tengo para mi, que si hoy padece el Tribunal Constitucional una fuerte crisis de legitimación por las circunstancias reseñadas, tal crisis sería aún más intensa si el órgano competente fuera el actual Tribunal Supremo español.

2. A la segunda parte de la pregunta contestaré, en alguna medida, en las respuestas ulteriores, pero ello no me exime de alguna breve reflexión. Desde luego, el único requisito constitucional para ser Magistrado que se ha respetado de forma permanente (y no sin alguna discrepancia en los últimos tiempos) es el requisito objetivo y empíricamente demostrable de los «más de quince años» de ejercicio profesional, además, obviamente, del también absolutamente objetivo y verificable de ser «Magistrado, Fiscal, profesor de Universidad, Funcionario Público (es de suponer que jurista) o Abogado. El otro requisito, que es una exigencia tan constitucional como los dos anteriores, el de la «reconocida competencia» fue razonablemente satisfecho en los primeros tribunales pero hay una conciencia muy extendida de que se ha ido degradando en la medida que se ha ido implantando el sistema de «cuotas» con libre y unilateral disposición de la propia. En este sistema el acuerdo de los tres quintos de parlamentarios, con independencia de la tramitación formal, no recae sobre las singulares personas propuestas sino sobre el reparto. A partir de aquí cada grupo parlamentario con cuota designa al suyo o los suyos. Se difumina, pues, el control que cada grupo pueda realizar sobre la reconocida competencia de los propuestos por el otro. Todo ello sin dejar de reconocer que, a mi juicio, la mayoría de los nombramientos puedan haber recaído sobre personas de reconocida competencia. Pero no todos, ni siempre los mejores posibles. Y ello es lógico en la medida que, en el criterio de los partidos, ha ido prevaleciendo la afinidad sobre cualquier otra consideración.

El de «reconocida competencia»es un concepto jurídico indeterminado de difícil aplicación. Pero si es difícil precisar con parámetros ajustados qué deba entenderse por tal, no es sin embargo demasiado difícil considerar ante un caso concreto que tal competencia no es del nivel suficiente o no goza de un reconocimiento digno de consideración. Supongo que la competencia constitucionalmente exigida para desempeñar tan altas funciones no es el mero y digno ejercicio de una actividad profesional porque tal desempeño no genera un notorio reconocimiento (se supone que de la comunidad jurídica).

En cualquier caso, me veo sin espacio, y confieso que sin muchas ganas, para esforzarme ahora en la determinación del indeterminado concepto, porque veo muy difícil el intento de delimitarlo imperativamente, es decir, con fuerza jurídica de obligar ya sea mediante desarrollo normativo o ya sea mediante control jurisdiccional.

En efecto, si bien todos podemos percibir de manera homogénea cuándo una persona no tiene un notorio reconocimiento de su calidad profesional entre los miembros de la «comunidad jurídica» ( aún cuando sea un dignísimo funcionario o un dignísimo abogado), y si también es fácil que seamos capaces de ponernos de acuerdo en que algunas personas tienen un alto e inequívoco reconocimiento, veo extremadamente difícil, y acaso perturbador, el establecimiento por vía de desarrollo legal de parámetros radicalmente objetivos. ¡Sólo nos faltaría una ANECA para «acreditar» a los pretendientes al empleo de Magistrado TC! 
Por otra parte, tampoco veo nada fácil el control externo. Puedo imaginarme perfectamente al Tribunal Constitucional rechazando (en virtud de lo dispuesto en el art. 2.1.g) de su Ley Orgánica) el nombramiento de un Magistrado porque ni ha sido nunca ni Magistrado ni Fiscal ni Profesor ni Funcionario ni Abogado, o porque no ha cumplido los 15 años de ejercicio profesional. Pero me resulta difícilmente imaginable rechazando un nombramiento, en virtud del citado precepto, por falta de reconocida competencia. Sería un caso tan extremo que no creo que ni siquiera nuestros partidos políticos se atrevieran a tanto (imaginémonos a un profesor de Universidad que no ha logrado ser acreditado para el puesto de contratado doctor después de más de 15 años de ejercicio profesional como profesor ayudante en cuatro Universidades distintas.)

Bromas aparte, me temo que el cumplimiento del requisito, más que de difíciles concreciones normativas o de improbables controles jurisdiccionales, depende del procedimiento de selección y de la cultura democrática y de la lealtad constitucional de los partidos políticos. Una cultura y una lealtad que determinen que, a partir de la obvia exigencia de integridad ética e independencia política, los seleccionados deban ser los mejores de los posibles. Siempre habrá inevitables desviaciones y disparidad de criterios sobre la excelencia, pero de lo que se trata es de mantener un criterio y un comportamiento razonables.

Hasta que se produzcan, si se producen, reformas más profundas, urge que los partidos tomen conciencia de lo inadecuado del sistema de selección que han ido implantando. (Si los partidos mayoritarios no adquieren esa conciencia será tan imposible cambiar los hábitos como cambiar las normas que, al cabo, dependen de su rotunda hegemonía parlamentaria). Creo que lo más urgente no es cambiar ni el sistema de justicia constitucional ni la estructura o composición del Órgano, sino el procedimiento de selección.

Hace algún tiempo tuve ocasión de pronunciarme sobre este procedimiento y sostenía entonces - y sigo sosteniendo ahora - que lo inadecuado no es el «sistema de cuotas» sino «el sistema de cuotas con libre disposición unilateral» de la correspondiente a cada grupo. Me explico.

Es una cuestión de «legitimación democrática indirecta» y no, desde luego, de legitimidad. Ya se ha dicho que la incuestionable legitimidad del Tribunal le viene de la potestad y las competencias que la Constitución le atribuye y de su respeto al Derecho que ha de aplicar, de su efectiva vinculación a una voluntad ajena que, con las dificultades que sean (que no son pocas), está obligado a respetar, interpretar y aplicar con razonada objetividad. Pero la designación de los Magistrados por órganos representativos ofrece la ventaja de que los vincula con las cambiantes mayorías sociales y la cambiante percepción social de los valores, tan presentes en la interpretación constitucional. Naturalmente, no hablo de dependencias políticas sino de sensibilidades jurídicas legítimas y distintas. En este sentido, es perfectamente razonable, en términos de legitimación y aún de funcionalidad, que la fuerza más representativa pueda seleccionar un número determinado, más o menos próximo a su representatividad.

Hasta aquí, según creo, la dimensión legítima de las cuotas. Pero, una vez convenido cuántos Magistrados le corresponde proponer a cada Grupo Parlamentario, la selección no puede ser unilateral y libérrima sino que deberá alcanzarse el consenso sufi- 
ciente sobre cada nombre; individuo a individuo; con un escrutinio individual lo más exigente y objetivo posible. He sugerido algunas veces la elaboración conjunta, prudente y discreta, de listas de posibles candidatos que respondan a las respectivas sensibilidades y que una vez aceptada la lista (en la que cada Grupo puede sugerir candidatos propios y candidatos del otro que le parezcan aceptables) cada Grupo procedería a designar los elegidos del «cupo» del otro. Al menos se conseguiría la selección de los más independientes. No quiero ir más allá en un ejercicio arriesgado que puede rozar la frontera del arbitrismo.

Lo que tengo claro, con independencia del método formal, es que si se quiere que el Tribunal Constitucional recupere el alto prestigio que un día tuvo, es preciso retornar a la práctica inicial, a aquella que llevó a la UCD y al PSOE a seleccionar conjuntamente, con acuerdo singular de todos sobre cada candidato, si no a los «mejores», sí a un Tribunal compuesto por personas especialmente cualificadas y «reconocidas» como grandes juristas, y profundamente independientes, sin perjuicio de que, ¡naturalmente!, sus ideologías políticas y sus sensibilidades jurídicas fueran distintas.

\section{ViCENTE GIMENO SENDRA}

La composición del Tribunal Constitucional me parece correcta, lo que resulta lamentable es el incumplimiento, en estos últimos tiempos, del requisito de «juristas de reconocida competencia», que establece el núm. $2^{\circ}$ del art. 159 C.E., pues, tengo la impresión de que, como consecuencia del fenómeno anteriormente mencionado, la elección se realiza, en ocasiones, más en función de la fidelidad a un determinado partido político que por los conocimientos jurídicos del aspirante.

\section{JAVIER PÉREZ RoYo}

Composiciones óptimas no existen. Hay composiciones disparatadas, como la del Tribunal de Garantías Constitucionales de las Constitución de 1931, pero no composiciones óptimas.

En general no existe composición óptima de ningún órgano constitucional. La organización institucionalizada de la convivencia no es un bien deseable, sino un mal necesario. Desde esta perspectiva tiene que ser contemplada la composición de cada uno de los órganos constitucionales. El criterio del mal menor es el que debe presidir el diseño constitucional.

En el caso del Tribunal Constitucional más que en ningún otro, porque habla siempre en último lugar y, como consecuencia de ello, nunca se equivoca.

En la Europa continental se ha alcanzado un consenso sobre la composición de los Tribunales Constitucionales, de tal manera que se podría decir que existe una suerte de norma europea en este terreno. No hay dos Tribunales Constitucionales que tengan la misma composición, pero hay la suficiente homogeneidad como para que de la composición de todos ellos se deduzca una norma común. España encaja dentro de ella. No me parece mal. No la cambiaría. 
La apreciación del requisito de la reconocida competencia es una cuestión de cultura constitucional. No se puede resolver normativamente.

\section{Ramón Punset Blanco}

Sin perjuicio de lo que he de precisar en la contestación a la siguiente pregunta, respondo ahora que juzgo atinada la composición del TC instituida por el art. 159.1 CE y la participación en ella de los distintos poderes del Estado. Verdad es, no obstante, que la acción uniformemente difuminadora de los partidos políticos relativiza dicha participación pluriorgánica, y que las mayorías muy cualificadas acertadamente exigidas por el constituyente (y por el art. 127.1 b) LOPJ) en orden a la elección de los Magistrados se hallan contrarrestadas por la viciosa práctica del sistema de cuotas entre las principales fuerzas partidarias. A pesar de esto no encuentro otra alternativa al modelo actual que el de la judicial review, bien en su típica modalidad de control difuso, bien reservando el monopolio del rechazo al Tribunal Supremo (ya, a su vez, a una nueva Sala de éste, ya a una Sala Especial de integración transversal). Por toda suerte de razones, no soy partidario de semejante modelo. Además, la pluralidad de orígenes profesionales del colegio de jueces constitucionales («Magistrados y Fiscales, Profesores de universidad, funcionarios públicos y Abogados», reza el art. 159.2 CE de manera que no hay que entender exhaustiva, como, en cambio, parecen hacer el art. 18 LOTC y la STC 101/2008, FJ 5) la considero sumamente enriquecedora.

El requisito de que «todos» los Magistrados del TC han de ser «juristas de reconocida competencia, con más de quince años de ejercicio profesional», no resulta, desde luego, ocioso, ni debe contemplarse irónica o escépticamente como si fuera un flatus legis. Por eso, y no por motivos de control político, el artículo 16.2 de la LOTC determina desde la reforma legal de 2007 que «los candidatos propuestos por el Congreso y por el Senado deberán comparecer previamente ante las correspondientes Comisiones en los términos que dispongan los respectivos Reglamentos». Términos que el Reglamento del Senado circunscribe al objeto de que dicha comparecencia, hoy obligatoria, ante la Comisión de Nombramientos (presidida por el Presidente de la Cámara e integrada por los Portavoces de los Grupos Parlamentarios) tenga lugar, «una vez comprobado el cumplimiento de los requisitos exigidos por la Constitución y las leyes para desempeñar el cargo», solamente para que los miembros de la Comisión puedan «solicitar al candidato aclaraciones sobre cualquier extremo relacionado con su trayectoria profesional o sus méritos personales». La Comisión ha de elevar al Pleno un informe «sobre la idoneidad de los candidatos» para acceder al cargo (art. 185.1, 3, 4 y 6). Además de todo esto, y como es bien sabido, el propio Tribunal verifica el nombramiento de los Magistrados, "para juzgar si los mismos reúnen los requisitos requeridos por la Constitución y la presente Ley» (art. $2.1 \mathrm{~g}$ f LOTC). Según se advierte, tanto este control a posteriori del TC como el de carácter preliminar previsto en el artículo 185.3 RS son absolutamente reglados, ya que se dirigen únicamente a comprobar que se trate de juristas con más de quince años de ejercicio profesional («o en activo en la respectiva función», añade el art. 18 LOTC); mientras que el informe de idoneidad de la Comisión parlamentaria ha de versar a propósito de la «reconocida competencia» constitucionalmente demandada, lo que im- 
plica una apreciación discrecional (que nunca debiera degenerar en arbitraria) sobre la entidad de los méritos de los candidatos.

\section{Juan Alfonso Santamaría Pastor}

La segunda cuestión comprende dos interrogantes de naturaleza muy distinta.

Comenzando por el segundo, por su mayor sencillez, la respuesta ofrece pocas dudas, desde mi punto de vista: la reconocida competencia y los quince años de ejercicio profesional son, sin duda, requisitos acumulativos que han de concurrir simultáneamente en todos los candidatos. La dicción literal del precepto constitucional es, por sí sola, muy clara; de otra forma, hubiera empleado una fórmula disyuntiva. Pero una interpretación lógica de la norma lleva a la misma conclusión: enumerar esos requisitos como una alternativa, o admitirlo por vía interpretativa, conduciría al absurdo de permitir el acceso al Tribunal a viejos profesionales de manifiesta incompetencia jurídica. Es cierto que la historia ofrece ejemplos que parecen contradecir este presupuesto de exigencia, como el del Chief Justice Marshall; pero en la actualidad, la interpretación constitucional presenta unos rasgos de extrema sofisticación, inalcanzables para la generalidad de los juristas. La intuición y el buen sentido, por importantes que sean, ya no bastan para desempeñar el cargo de Magistrado del Tribunal.

El primer interrogante, por su parte, suscita cuestiones de mucha hondura. Con el fin de ordenar las ideas, creo que podría ser contestado desde dos perspectivas.

Primera, la positiva (esto es, lo que el precepto constitucional dice). Desde ella, el texto no parece fácilmente mejorable. Nada hay que objetar a la selección de los colectivos de los que han de provenir los candidatos, ni tampoco a los dos requisitos de competencia y experiencia a los que acabo de referirme. Quizá el primero de ellos pueda ser considerado poco específico, pero su significado y finalidad son evidentes, aparte de que no sería nada sencillo (ni usual) acumular adjetivos con ánimo de incrementar el nivel de exigencia; ni tampoco útil, porque tales adjetivos seguirían siendo conceptos indeterminados y de apreciación siempre opinable. El problema, al que aludí al contestar la cuestión anterior, no es de redacción del texto constitucional, sino de los parámetros empleados por los partidos políticos para seleccionar a sus candidatos, que progresivamente han venido a primar la fidelidad o la afinidad ideológica, comprobando sólo después si las personas preseleccionadas reunían un cierto nivel de prestigio, de manera que no los hiciera abiertamente cuestionables. No es, en suma, una cuestión de redacción normativa, sino de la posposición a un lugar secundario de lo que hoy ha dado en llamarse cultura de la excelencia.

Como España es el país de las susceptibilidades, quizá deba decir que sólo en contados casos he podido percibir en los colectivos profesionales a los que pertenezco ( $\mathrm{mi}$ opinión personal no cuenta, obviamente) un juicio mayoritariamente negativo acerca de la competencia en derecho de un concreto Magistrado. No trato de quedar bien con los amigos, que son felizmente muchos, sino de ser justo con ellos; pero excepciones las ha habido, desde luego. Es notorio que por el Tribunal han pasado (y están actualmente) muchos de los mejores juristas del país: pero también lo es que han tomado asiento en el mismo contados profesionales a los que jamás hubiéramos encomendado un asunto mínimamente complejo. 
Y segunda, la perspectiva negativa: lo que la norma constitucional no dice y quizá hubiera debido decir (ella, o quizá la ley orgánica del Tribunal; no tengo claro si la enumeración de requisitos que el artículo 159 hace debe considerarse cerrada). Si pretender apurar el requisito de la reconocida competencia es tan estéril como intentar poner puertas al campo, creo que, a la luz de la experiencia, el bloque de la constitucionalidad podría y debería incluir algunas circunstancias excluyentes que reforzaran la independencia (o su imagen) de los Magistrados.

A título de ejemplo, y simplemente indicativo de una línea de pensamiento: me parece desaconsejable que puedan llegar a formar parte del Tribunal personas formalmente afiliadas a un partido político (en un país donde la afiliación formal es mínima), o que, sin estarlo, hayan formado parte de listas electorales de partido, o hayan sido designadas para ocupar altos cargos de designación gubernativa (no todos, por supuesto) en las Administraciones o en otros órganos públicos en los años anteriores a su designación. Me parecería, por ello, bastante razonable que, por lo menos, algunas de las incompatibilidades que establece el artículo 159.4 de la Constitución (las tres primeras) operasen también como causas de inelegibilidad para quienes hubieran desarrollado tales actividades en los años anteriores a su nombramiento. Y creo, igualmente, que no sería ocioso en establecer otras prohibiciones que aseguraran un comportamiento personal intachable en el pasado; que renuncio a enumerar, por evidentes. Ignoro en este momento si tales circunstancias excluyentes han concurrido en alguno de los Magistrados, porque no pienso en ninguno en particular.

Probablemente se estime que tales cautelas son innecesarias, porque los líderes de los partidos las toman en cuenta para blindar ante la opinión su selección de candidatos. Pero si es así, tampoco sobrarían: después de ver a condenados por delitos de terrorismo ocupar la presidencia de alguna comisión de derechos humanos, toda prevención parece escasa. Y tampoco me parecería estimable la objeción de que la concurrencia de tales causas no impide que tales personas sean, en la práctica, totalmente independientes en su criterio, porque la imagen que su trayectoria ofrecería a la generalidad de la población es decisiva; como la de la mujer del César.

3. ¿Nos quiere formular algún comentario acerca de la LO 6/2007, de 24 de mayo, que reforma varios preceptos de la LOTC y, más específicamente, sobre su incorporación de la presentación de candidatos a ser magistrados por las Asambleas Legislativas de las CCAA al Senado?

\section{Luis Aguiar De LuQue}

Desde el punto de vista constitucional, los interrogantes que pudiera suscitar dicha reforma legal han quedado despejados por la STC 49/2008, de 9 de abril, que con una correcta y aquilatada argumentación delimitó la justificación constitucional del texto legal y el alcance que puede tener la presentación de candidatos por los parlamentos autonómicos, para que no se vea desvirtuada la plena disponibilidad que la Constitución otorga al Senado para formular propuestas de nombramientos de magistrados constitucionales. 
Mayores dudas me suscita la reforma en cuanto a lo que pueda aportar en orden a la mejora del régimen jurídico de la jurisdicción constitucional en nuestro ordenamiento.

Hoy es pacíficamente aceptado que la regulación constitucional del Senado, pensado para una ordenación territorial del Estado que nada tiene que ver con el modelo que finalmente ha prosperado en nuestro desarrollo constitucional, no se adecúa en absoluto al actual nivel del estado autonómico. Las reiteradas propuestas de reforma de la cámara alta, incluido un fallido proyecto de reforma constitucional así lo confirma.

Pues bien, la reforma legal ahora comentada, se desenvuelve más en la lógica de dotar de mayor contenido a la caracterización del Senado como cámara de representación territorial (art. 69.1 de la Constitución), que a perfeccionar nuestro sistema de jurisdicción constitucional.

Sin embargo la reforma de la LOTC ni potencia realmente la dimensión territorial del Senado (algo que probablemente solo puede lograrse a partir de una reforma constitucional que modifique de un lado la composición del Senado y el modo de reclutamiento de los miembros y de otra que amplíe el elenco de funciones con significación autonómica) ni sirve para dotar de proyección autonómica en la composición del Tribunal pues tan solo da una apariencia de participación de los parlamentos autonómicos pero que en verdad carece de autentica significación jurídica como la experiencia se ha encargado de poner de manifiesto.

En contra, el nuevo sistema de nombramiento de magistrados constitucionales por el Senado proyecta una imagen de representatividad de intereses territoriales por los magistrados así nombrados que creo que no contribuye mejorar nuestro sistema de jurisdicción constitucional a la par que distorsiona en el imaginario colectivo el papel del Tribunal Constitucional en nuestro régimen constitucional.

\section{Francisco Javier Díez Revorio}

La LO 6/2007 ha llevado a cabo la que sin duda ha sido la más trascendente reforma de la LOTC desde su aprobación, incidiendo en aspectos de gran importancia. Cabe destacar una nueva regulación del recurso de amparo, cuyo trámite de admisión se transforma pasando a una regla general de inadmisión, salvo en los casos en los que se acredite la «especial trascendencia constitucional del recurso». Según muchos autores, ello implica una significativa atenuación (o para algunos, la pérdida total) de la dimensión subjetiva de recurso de amparo, lo que puede resultar cuestionable desde diversos criterios. Aunque todavía es pronto para llevar a cabo una valoración del funcionamiento de la reforma con suficiente perspectiva, sí parece que la misma está contribuyendo a descongestionar al Tribunal, y a disminuir el retraso del mismo en la resolución de los recursos de amparo.

La reforma de 2007 incidió también en otros muchos aspectos, entre los que cabe destacar cuestiones de organización y funcionamiento del Tribunal, tratando de desconcertar su actuación dando más peso a las secciones frente a las salas, y a estas frente al Pleno. Igualmente se introdujeron algunas novedades para tratar de evitar los conflictos con el Tribunal Supremo, delimitando en algunos aspectos la posición y funciones de cada uno de los dos altos tribunales, entre otros aspectos de interés que no podemos aquí detallar y que son suficientemente conocidos. 
Entrando brevemente en el aspecto concreto propuesto en la pregunta, la reforma de 2007 introduce dos novedades significativas en lo que atañe a la designación de los magistrados propuestos por el Congreso y el Senado. Por un lado, se dispone en el art. 16.1 que los magistrados propuestos por el Senado lo serán entre los previamente propuestos por las asambleas legislativas de las comunidades autónomas. Esta fórmula añade un requisito no previsto en la Constitución, pero que ha sido considerado constitucional por el propio Tribunal en la STC 49/2008, de 9 de abril, y trata de dar respuesta a una reivindicación de algunos grupos políticos para que las comunidades tengan participación en la designación de magistrados del Tribunal. La nueva regulación ya ha sido aplicada en la última renovación del Tribunal, aunque la reiteración de algunos candidatos en diversas comunidades autónomas terminó por reducir el elenco de propuestas entre las que la Cámara alta pudo elegir. En definitiva esta nueva fórmula no parece lograr aminorar el protagonismo real de los partidos políticos en la propuesta de candidatos por las Cámaras.

Por otro lado, la reforma introdujo los exámenes previos de los candidatos propuestos por ambas Cámaras, que en parte también han comenzado ya a realizarse en la última renovación parcial del Tribunal. Estos exámenes, que son habituales en algunos otros ordenamientos, pueden tener utilidad en ciertos casos, aunque es difícil dar aún una valoración concluyente de los mismos; y desde luego no parece que sean un mecanismo eficaz para asegurar la competencia jurídica (en general, quienes examinan tienen muchos menos conocimientos y preparación en ese ámbito), sino como mucho para buscar una mayor transparencia y tratar de impedir el acceso al Tribunal de personas cuyo presente o pasado merezca reproches éticos o jurídicos a juicio de la Cámara o de alguno de los grupos parlamentarios; o para comprobar el cumplimiento de requisitos formales o cuantitativos previstos en la Constitución o en la ley y que puedan plantear dudas en algún caso concreto, aunque si estas dudas son de carácter estrictamente jurídico no es seguro que la Cámara sea el sujeto mejor cualificado para controlar el cumplimiento de dichas exigencias.

\section{Alfonso Fernández Miranda}

He estimado conveniente, acaso sin suficiente razón, la agrupación de todas estas preguntas $(3,4,5$ y 6 ) en una sola respuesta. Algunas de las cuestiones puntuales que en ellas se plantean han sido expresa o implícitamente respondidas en la valoración de carácter general que se ha hecho en la primera respuesta. El grueso de las cuestiones está referido a una valoración de las sucesivas reformas legislativas que se han venido haciendo, desde 2007, en la Ley Orgánica del Tribunal Constitucional.

Considero todas esta reformas, que me merecen una valoración muy desigual, una de las llamadas «ingerencias externas» que han influido, en su mayor parte de forma negativa en el prestigio del Tribunal. Por ello voy a desarrollar mi crítica afrontándolas una a una y sólo prescindiendo de aquellas puramente técnicas o de limitado alcance que, o no son especialmente relevantes o no han generado un notorio disenso.

1. La reforma relativa al nuevo modelo de recurso de amparo.

Esta reforma me merece, en principio, una valoración claramente positiva. Era una reforma necesaria si se quería detener el enorme retraso en las resoluciones del TC que es- 
taba produciendo un claro deterioro de la eficacia de su función depuradora y reparadora, y fue una reforma que, pese a algunos reproches doctrinales, estimo perfectamente conforme con la Constitución. Veamos:

\section{a) Necesaria.}

El TC se había convertido casi exclusivamente en un Tribunal de amparo con una grave desatención de los asuntos de Pleno (control de leyes y resolución constitucional de conflictos, funciones en las que, además, ningún otro órgano jurisdiccional podría sustituirle) La acumulación de asuntos resultaba ya claramente alarmante y estaba provocando un retraso que empezaba a ser inaceptable. Piénsese que solo en el año 2006 se presentaron más de 12.000 recursos de amparo y aunque se inadmitía el $96 \%$ de los interpuestos, los admitidos eran muchos más de los que cada año se podían resolver. El consiguiente retraso en las resoluciones había llegado a situarse en un plazo de entre tres y seis años. A su vez, eso provocaba otro retraso en los asuntos de Pleno, porque el $80 \%$ del trabajo de Magistrados y Letrados se dedicaba al amparo: cuestiones de inconstitucionalidad con procesos suspendidos, recursos de inconstitucionalidad y conflictos de competencia con leyes u otras normas autonómicas pendientes de sentencia, en muchos casos, durante un plazo de seis a once años. Esta situación, que estaba llamada a crecer inexorablemente, era obvio que no podía seguir. De otro modo no hubiera tardado demasiado en llegar el momento de echar el cierre a la institución por manifiesta inoperancia.

La oportunidad política de una reforma — con independencia de su validez jurídica que analizaremos seguidamente- ha de medirse por la eficacia de sus efectos y éstos son bastante más que esperanzadores. El Tribunal ya está prácticamente al día en amparos y es razonable suponer que, como consecuencia de ello y en el medio plazo, estará en condiciones de eliminar los retrasos en los asuntos de Pleno.

\section{b) No contradictoria con la Constitución.}

Los términos «en su caso» del artículo 53.2 CE y «en los caso y formas que la ley establezca» del art. 161.1.b) dejaban margen suficiente al legislador para la reforma que se ha efectuado. Además, la función de «tutela» de derechos (art.53.2 CE) no ha desaparecido. Solo que, siendo requisito indispensable para recurrir (si no se alega vulneración del derecho o si, aun haciéndose, esa vulneración no es apreciada a limine como verosímil, el TC inadmitirá), ya no es por si solo requisito suficiente. Se le adiciona, necesariamente, un elemento objetivo: poseer ese amparo concreto una «especial trascendencia constitucional». Es decir, se unen, de manera indisociable, el elemento subjetivo de tutela con el elemento objetivo de la especial trascendencia. La sentencia que se pronuncie, si estima el amparo, tendrá también esa doble e indisociable condición: otorgar la tutela subjetiva al recurrente y establecer criterios (doctrina) generales (elemento objetivo) sobre el correspondiente derecho.

Ahora bien, afirmaba al iniciar este somero análisis que mi valoración era, en principio, positiva. Y esta cautela merece alguna explicación. El artículo 50 b) de la LOTC fija con relativa precisión (relativa por que no exime de la necesidad de interpretar y valorar) en qué consiste la «especial trascendencia constitucional», pues deberá apreciarse «atendiendo a su importancia para la interpretación de la Constitución, para su aplicación o 
para su general eficacia, y para la determinación del contenido y alcance de los derechos fundamentales». Los criterios parecen claros pero tienen margen de indeterminación interpretable y el sistema no ofrece mecanismos efectivos para garantizar la homogeneidad de las prácticas en ambas Salas. Aún es pronto para sacar conclusiones pero tengo la impresión de no existe una rigurosa homogeneidad de actuación. Ello es una puerta abierta a la inseguridad jurídica y no me gustaría que, como ocurre por desgracia en otros órganos judiciales, nos encontráramos a letrados aguardando que pase un turno para que el reparto les sonría con la Sala más propicia a sus intereses..

2. La reforma relativa a la descentralización de asuntos del Pleno en las Salas.

Me merece también una valoración positiva. Servirá para descargar de trabajo al Pleno en asuntos de mera aplicación de doctrina (que son entre el 80 y el $90 \%$ de los asuntos de Pleno), con la garantía de que siempre queda en las manos del Pleno avocar para si la resolución final de asuntos que en su día hubiese deferido a las Salas. Así se garantiza — lo que no cabe en las admisiones_ - que las Salas no se extralimitan no aplicando exactamente la doctrina anterior, o que un asunto que en principio hubiere parecido pacífico resultara no serlo, siendo entonces preferible que vuelva al Pleno.

3. La reforma relativa a la prórroga de los mandatos de Presidente y Vicepresidente por retrasos en la renovación de Magistrados.

Esta reforma, que en conjunto no aprecio en absoluto, tiene un elemento positivo, aunque no fuese de ninguna manera la razón política que la propició, que también conviene destacar. Con anterioridad, en la LOTC no se hacía explícito que el Presidente y Vicepresidente siempre deberán ser elegidos cuando se produzca cada tres años la renovación por tercios del Tribunal. Parece obligado, por respeto a la autonomía interna del órgano y al principio democrático, que el Presidente y Vicepresidente sean elegidos por Magistrados que a partir de entonces van a estar en el Tribunal.

Sin embargo esta reforma, lejos de servir de mecanismo para impulsar en tiempo y forma las renovaciones como la Constitución reclama, puede alentar los retrasos por razones de conveniencia política. No se podrá evitar la sospecha — no se ha evitado en su primera aplicación práctica - de que esos retrasos, que aseguran sine die la prórroga de Magistrados, de Presidente y de Vicepresidente, obedecen a un interés político de quien se siente cómodo con ese Tribunal. Y no puede olvidarse que esta sospecha refuerza poderosamente la idea de falta de independencia de algunos o de muchos Magistrados.

4. La reforma relativa a la intervención de las Comunidades Autónomas en la designación de Magistrados por el Senado.

Mis dudas sobre la Constitucionalidad de esta reforma ya las expuse, entre otros sitios, en la citada contestación a la Encuesta del N 21 de esta Revista. El Tribunal (un Tribunal con una mayoría que no podrá ser acusada de falta de deferencia, no se si con el Legislador, pero si con este legislador) salvó tan cuestionable constitucionalidad con dos sentencias interpretativas (una sobre esta reforma de la LOTC y otra sobre la consiguiente reforma del Reglamento del Senado). Para salvarla no tuvo más remedio —a fin de no cargarse simultáneamente y de un solo tiro el tenor literal de la Constitución y la autonomía parlamentaria del Senado- que rechazar el carácter vinculante de las propuestas 
de las Asambleas de las Comunidades Autónomas. El resultado final es una piedra más en el oxidado engranaje de la renovación de Magistrados que no satisface los intereses políticos de quienes promovieron la reforma y que viene a complicar notoriamente los procesos de renovación.

En efecto, esta reforma fue promovida y aprobada por pretendidas (y legítimas, salvo el problema de constitucionalidad) razones de oportunidad, no se si para complacer intereses autonómicos o para abrir un atajo inadecuado e intransitable hacia la federalización del Estado. Pero una vez reducido el trámite a una propuesta no vinculante, la pretendida oportunidad se convierte en pura inoportunidad. Nada más políticamente inoportuno que lo que conduce a la innecesaria e inútil complicación y a la ineficiencia del sistema.

Esta reforma no tiene más que inconvenientes y ninguna ventaja. Como las propuestas de las Asambleas Autonómicas no son vinculantes, salvo acuerdo previo de los dos grandes partidos antes de que se pronuncien los parlamentos autonómicos (lo que sería muy poco edificante para la autonomía institucional de las Asambleas legislativas autonómicas y la más nítida negación de las pretensiones federalizantes) lo que consigue esta reforma es alargar el proceso de renovación y poner las propuestas, al final, en la tesitura de que sólo se aceptarán si, después, en el Senado, se ponen de acuerdo los dos grandes partidos. ¡Abruma la inutilidad del esfuerzo!

Obviamente, y por decirlo de la forma más sencilla, la partidocracia que nos gobierna convierte este procedimiento en cínicamente retardatario e inútil.

5. La reforma relativa al retraso de las renovaciones de Magistrados y al acortamiento que ello ocasiona en el mandato de los Magistrados que vendrán a sucederles.

Es éste un pésimo sistema y, además, en la medida en que se ha establecido con carácter general, incompatible con la Constitución por cuanto en ésta, en su artículo 159.3, se dispone con claridad que los Magistrados serán nombrados por un período de nueve años.

Es cierto que la coyuntura que se dio (culpable y además inconstitucional) por el retraso de la renovación del tercio correspondiente al Senado, que se prolongó ni más ni menos que tres años, exigía una solución ad causum pues, de otro modo, se hubiera incumplido el mandato también constitucional de que las renovaciones por tercios hayan de hacerse cada tres años. De manera excepcional y para este único supuesto, pudiera haber sido plausible, diciéndolo expresamente en la reforma ad hoc, que los nuevos Magistrados hubiesen visto acortado su mandato a seis años (como ya había sucedido, por interpretación del propio Tribunal, en supuestos de fallecimiento o renuncia de Magistrados), manteniéndose así la renovación por tercios cada tres años y haciéndola prevalecer sobre la duración de nueve años del mandato, ya que en tales supuestos las dos prescripciones constitucionales entraban en conflicto.

Lo que se ha hecho - con carácter general y no como coyuntural solución a un problema concreto- además de inconstitucional (aunque tal inconstitucionalidad nunca llegue a declararse) es insensato porque alimenta las peores prácticas de la partidocracia dotándolas de normalidad y de aparente cobertura legal. Es cierto que si las Cámaras o, en realidad, los dos grandes partidos que tienen en su mano la renovación, no cumplen con su obligación de renovar, poco se puede hacer internamente puesto que las Cortes 
Generales son inviolables. Pero resulta lamentable que el legislador, en vez de buscar fórmulas capaces de forzar a las Cámaras al cumplimiento de los plazos, haya venido a dar carta de naturaleza al incumplimiento. Me parece obvia la inconstitucionalidad (insisto: no en lo que tiene de solución puntual sino de regla general) por su manifiesta incoherencia con el taxativo mandato de nueve años que la Constitución consagra. Pero además, y también insisto, me parece insensato.

Lo que esto pone de manifiesto una vez más (y es una idea sobre la que ya me ha expresado en la respuesta a la segunda pregunta) es que el Estado constitucional democrático no puede sustentarse exclusivamente en la fuerza del Derecho, sino también, necesariamente, y a veces sobre todo, en la cultura democrática de los dirigentes y en su lealtad constitucional. Y cuando no se produce el cumplimiento político de las reglas del juego, el Estado democrático se erosiona y se deslegitima. Pero también es cierto que las cosas se agravan en extremo cuando el Derecho, en vez de dificultar el incumplimiento, lo facilita como ahora sucede. Seguramente no puede impedirlo por si solo frente a la falta de lealtad, pero si puede dificultarlo seriamente.

Para dificultar el retraso en la renovación de los Magistrados podía haberse adoptado, por ejemplo, la fórmula alemana. La Ley del Tribunal Constitucional Federal alemán (art. 7.a) prevé que si transcurridos dos meses desde la expiración del mandato o del cese anticipado de Magistrados no se hubiere realizado la elección de los sucesores de acuerdo con los procedimientos establecidos, el Tribunal Constitucional en Pleno propondrá al órgano constitucional al que cumple elegir, una lista de candidatos en número doble de los puestos a cubrir y, llegadas esas propuestas al correspondiente órgano constitucional, éste será convocado inmediatamente para designar a los Magistrados ya sea entre los propuestos por el Tribunal o entre otras personas. Esta solución de que, de forma muy rápida, sea el propio Tribunal el que proponga candidatos en caso de bloqueo de las negociaciones entre los partidos, y esa celeridad que por ley se da a la renovación, hace mucho más difícil los retrasos que superen los dos meses. De hecho, en Alemania, esta simple previsión ha resuelto por si sola el problema.

Mas, volviendo a la actual situación española, conviene no olvidar que hace tres años que falleció el Magistrado Roberto García Calvo (elegido por el tercio del Congreso) sin que se haya designado sustituto. Pese a que la Constitución dice que el Tribunal se compondrá de doce miembros, desde entonces está incompleto y funciona con once.

Hace más de siete meses que debieron renovarse los otros tres Magistrados correspondientes al Congreso sin que, a día de hoy (21 de julio), la renovación se haya producido. Es cierto que en el pasado ha habido otros retrasos de igual o mayor duración pero, de una parte, la repetición del mal no lo sana sino que lo agrava y, de otra, hay una diferencia porque ahora, por obra de las reformas de la LOTC, el mal es de mucha mayor gravedad puesto que el retraso produce Ex lege, lo que antes no sucedía, el acortamiento del mandato de los que en su día vengan a sustituir a los ahora prorrogados. No es preciso subrayar en exceso la dañina dimensión constitucional y política de este estado de cosas.

A lo antedicho deberán sumarse las dudas que suscita la pertinencia, constitucional y legal, de la designación de uno de los Magistrados caducados y en prórroga, como Vicepresidente del Tribunal. Dado el tenor literal del artículo 17.2 de la LOTC, que dispone que los Magistrados en prórroga de mandato «continuarán» en el ejercicio de 
«sus funciones», lo lógico es pensar que se están prorrogando las funciones de Magistrado, pero no parece que se esté habilitando para ejercer otras funciones distintas como la de Presidente o Vicepresidente o para acceder a ellas durante la prórroga en la medida en que entonces ya no se está continuando una función sino accediendo ex novo a otra.

Pero al margen de la discutible constitucionalidad (y ya es grave que la mayor parte de las reformas de la LOTC o de su aplicación, se hayan movido siempre en el filo de la navaja con clara tendencia a traspasar la frontera) hay otra reflexión política de la máxima importancia: ¿Por qué se acepta ser Vicepresidente de un órgano en el que uno se encuentra en situación de irregularidad constitucional y pendiente de una renovación que, por pura lealtad institucional, debería desearse inmediata? Todas las respuestas posibles me desazonan profundamente.

6. Atribución en exclusiva al Tribunal Constitucional del control de las normas forales fiscales de los Territorios Históricos del País Vasco.

No parece adecuarse a la Constitución que lo que son Reglamentos (así es reconocido incluso por la misma reforma de la LOTC) se sustraigan al control de la jurisdicción ordinaria atribuyéndose su control en exclusiva, mediante el recurso y la cuestión de inconstitucionalidad, al Tribunal Constitucional. No parece que los artículos 106.1 y 153.c) CE, que otorgan a la jurisdicción ordinaria el control de la potestad reglamentaria, ni que los artículos 161.1 y $163 \mathrm{CE}$, que limitan el recurso de inconstitucionalidad y la cuestión de inconstitucionalidad al control de las leyes y normas con fuerza de ley, permitan hacer lo que se ha hecho. Además, el artículo 161.1.d) si bien faculta a que por leyes orgánicas se atribuyan otras competencias al Tribunal Constitucional, impide que tal ampliación desfigure las competencias que la propia Constitución ya le atribuye y que sustraiga al Poder Judicial las competencias que la propia Constitución le ha asignado.

Pero acaso lo peor (y ya es mucho decir porque hablamos de una inconstitucionalidad) es una reflexión de naturaleza política. Asusta la frivolidad con que se juega con la Constitución y asusta más, porque la razón más probable no es la búsqueda del interés general sino el pago por unos votos en el Congreso de los Diputados.

\section{VicENTE GIMENO SENDRA}

Me parece correcta la reforma, habida cuenta de la vocación del Senado como Cámara de representación territorial.

\section{JAVIER PÉREZ Royo}

La LO 6/2007 es un intento más de los varios que ha habido para que el Senado desempeñe las funciones que tiene constitucionalmente encomendadas de una manera más acorde con su definición como «Cámara de representación territorial» (art. 69. 1), sin proceder a la reforma del mismo.

Como ha ocurrido con los anteriores, también en este caso el resultado ha sido un fracaso. No hay sustitutivos para la reforma del Senado. 


\section{RAMÓN PUNSET BLANCO}

Se me disculpará que empiece mi respuesta por la cuestión más específica y reiterando en primer término lo dicho en otro lugar. La Constitución de la II República preveía que formase parte del Tribunal de Garantías Constitucionales «un representante por cada una de las Regiones españolas» (art. 122), pero no fue ése el modelo seguido por la actual Constitución, cuyos autores deliberadamente quisieron apartarse de él, habida cuenta del fracaso a que le condujo su extremada politización, ocasionada, entre otros factores, por su disparatada composición. Hoy ni el Senado es, por su estructura, una verdadera Cámara de representación territorial ni la Constitución otorga a las Comunidades Autónomas intervención alguna en el proceso de designación de los cuatro Magistrados del Tribunal Constitucional que le corresponde elegir al Senado.

Dicho esto, la intervención autonómica señalada resultaría enormemente conveniente, ya que al Tribunal Constitucional le está asignada una función de capital importancia en nuestra forma territorial del Estado: la de dirimir los conflictos competenciales entre el sector central del aparato estatal y los entes políticamente autónomos, o los de éstos entre sí; conflictos que cabe viabilizar a través de la mayoría de los procesos constitucionales diseñados en la LOTC. De ahí la necesidad de que las Comunidades Autónomas tengan voz y voto en la elección de los integrantes del órgano jurisdiccional llamado a desempeñar, como supremo intérprete de la Constitución, tan trascendente función arbitral. Una voz, sin embargo, que sólo pueden hacer oír en el Senado — no cabe imaginar otro foro o método más idóneos-, y siempre que esta Asamblea, mediante la oportuna reforma de la Constitución, se convierta en una Cámara representativa de las Comunidades Autónomas, o sea, de la orientación política dominante en cada una de ellas. Así quedaría asegurada - y supondría una importante garantía de la autonomíala sensibilidad autonómica en el interior del Tribunal Constitucional, proporcionándose además al Tribunal una fuente adicional de legitimidad.

Pues bien: la Ley Orgánica 6/2007, de 24 de mayo, introdujo una novedad que se aparta de las previsiones constitucionales. «Los Magistrados propuestos por el Senado, dice desde entonces el artículo 16.1 II de la LOTC, serán elegidos entre los candidatos presentados por las Asambleas Legislativas de las Comunidades Autónomas en los términos que determine el Reglamento de la Cámara». Y tal Reglamento, modificado al efecto el 21 de noviembre de 2007, determina en su artículo 184.7 que, dentro del plazo que fije la Alta Cámara, cada Asamblea autonómica podrá presentar hasta dos candidatos. O sea, cabe que se presenten 34 candidaturas, únicamente dentro de las cuales designará el Senado a los cuatro Magistrados que le compete elegir. Resulta indudable, pues, la restricción inconstitucional de la libre potestad del Senado, restricción que corrobora el Reglamento citado cuando autoriza, sólo en el caso extremo de que no se presenten en plazo candidaturas suficientes (cuatro, se entiende), que las complete el propio Senado. Ello no obstante, el TC dio por válidas estas reformas en sus Sentencias 49 y $101 / 2008$.

En la STC 49/2008 se concluye, contra toda evidencia, en la ausencia de límites a la libérrima decisión senatorial sobre la elección de los cuatro Magistrados del Tribunal Constitucional y se justifica la participación de las Comunidades Autónomas en el proceso electivo con fundamento en la proclamación del Senado como Cámara de represen- 
tación territorial (art. 69.1 CE), justificación francamente discutible. El Voto Particular del Magistrado Conde Martín de Hijas constata que «el Senado no podrá elegir magistrados para el Tribunal Constitucional que no hayan sido previamente propuestos por las Asambleas Legislativas de las Comunidades Autónomas», y que la decisión mayoritaria salva la constitucionalidad del precepto impugnado (el art. 16.1 II de la LOTC) «a base de difuminar el sentido claro de lo que dice, ... convirtiéndolo... en un precepto distinto, irreconocible en su prístino sentido». Coincido con esta apreciación. También en el Voto Particular del Magistrado Delgado Barrio se advierte que la reforma legislativa elimina «la libertad del Senado para seleccionar, por sí mismo, los candidatos del art. 159.2 CE». Señala además acertadamente Delgado Barrio que la integración de la estructura territorial del Estado en la composición del TC a través de la actuación del Senado como Cámara de representación territorial «ha sido ya prevista y querida por la Constitución exactamente y en la medida que establece en sus arts. 69 y 159.1».

Por su parte, la STC 101/2008 (FJ 9 y 10) estira el concepto de «candidaturas suficientes» del artículo 184.7 b) RS, de claro significado numérico, hasta hacerlo coincidir con el de candidaturas merecedoras de «la confianza institucional del Senado», de modo que la «insuprimible» libertad institucional de la Cámara le permitirá no aceptar los candidatos propuestos por las Asambleas autonómicas y designar en su lugar otros propuestos por los Grupos Parlamentarios senatoriales. Así, mediante una interpretación conforme, opuesta a «un rígido entendimiento» del precepto reglamentario fundado en su «presunto tenor literal», y desechando igualmente la «voluntas legislatoris, derivada de los trabajos parlamentarios», el TC salva la constitucionalidad de la norma impugnada. Como escribí en otra ocasión, el Tribunal Constitucional, a través de este tipo de pronunciamientos, hace magia: pasa de la nomofilaxis constitucional, que es lo suyo, al ultramundo de la acción legiferante positiva, que no lo es en absoluto. En este caso la magia resulta tan elemental y tan torpe que cabe sospechar que el mago se halla plenamente convencido de la profunda idiocia del público. El Voto Particular, extenso y bien fundamentado, del Magistrado Conde Martín de Hijas me dispensa de aportar argumentos al respecto.

En lo que concierne a los demás aspectos de la amplia reforma de la LOTC llevada a cabo por la Ley Orgánica 6/2007, destacaré los más importantes o aquellos que contienen algún rasgo significativo.

La nueva redacción del artículo 4 comprende dos importantes previsiones, que tratan de blindar al TC frente a supuestos de actuación corsaria por parte del Tribunal Supremo: primera, el TC puede adoptar «cuantas medidas sean necesarias» para preservar su jurisdicción, «incluyendo la declaración de nulidad de aquellos actos o resoluciones que la menoscaben»; segunda, las resoluciones del TC «no podrán ser enjuiciadas por ningún órgano jurisdiccional del Estado». Nuestra singular guerra delle Corti debería hacerse así más difícil. Episodios como el de la pintoresca Sentencia de la Sala $1^{\text {a }}$ del Tribunal Supremo núm. 51/2004, de 23 de enero (contestada mediante Acuerdo del TC del 3 de febrero siguiente, antecedente claro del actual art. 4.2 LOTC, e impugnada surrealistamente en amparo, aún pendiente de resolver), pueden, empero, repetirse, porque siempre habrá juristas tan finos como el aspirante a académico de «La colmena». Y se han repetido en dos Sentencias de la Sala $3^{\text {a }}$ del TS: la de 26 de noviembre de 2009, que aborda el régimen de la responsabilidad patrimonial del TC (sobre la que procede remitirse al 
reciente estudio de C. Aguado Renedo), y la de 2 de junio de 2010, que sostiene la peregrina tesis de que corresponde a los órganos judiciales ordinarios resolver sobre la eficacia ex tunc o ex nunc de las sentencias declaratorias de la inconstitucionalidad de las leyes cundo en ellas no se contenga pronunciamiento alguno al respecto, con lo que se olvida la existencia del artículo 40.1 LOTC y se invade la exclusiva jurisdicción del Tribunal Constitucional en relación con las disposiciones de rango legal (véase, entre los Votos Particulares a dicha STS, el muy preciso y razonado formulado por el Magistrado Díez-Picazo Giménez).

Las previsiones mencionadas se complementan con la adición de un párrafo al artículo 92, en el que se faculta también al TC para «declarar la nulidad de cualesquiera resoluciones que contravengan las dictadas en el ejercicio de su jurisdicción, con ocasión de la ejecución de éstas» (véase el ATC 107/2009, de 24 de marzo, FJ 2 a 4).

En el artículo 10.3 se contiene una declaración más clara y completa de la autonomía presupuestaria del TC, la cual opera únicamente, empero, frente al Gobierno (que goza de reserva de iniciativa en la materia ex art. 134.1, 5 y 6 CE), no frente a las Cortes, a las que corresponden en todo caso, libérrimamente, la enmienda y aprobación de los Presupuestos (art. 134.1 CE).

También hay innovaciones en la regulación de la cuestión de inconstitucionalidad, que puede plantearse, una vez concluso el procedimiento, dentro del plazo para dictar sentencia «o la resolución judicial que procediese», según venía admitiendo ya la jurisprudencia constitucional desde el principio (STC 76/1982, FJ 1). La audiencia a las partes y al Ministerio Fiscal sobre la pertinencia de plantear la cuestión «o sobre el fondo de ésta» era igualmente una práctica usual (cfr. SSTC 166/1986, FJ 4, y 11/1999, FJ 1), como cabe suponer que lo fuera asimismo la previsión de suspensión contenida en el nuevo apartado 3 del artículo 35. Lo más reseñable, sin embargo, es que el apartado 2 del artículo 37 faculta a las partes del procedimiento judicial para personarse y formular alegaciones en el proceso constitucional. Esta doble intervención alegatoria potencial podría considerarse, en rigor, innecesaria, ya que el TC conoce, a través del testimonio de las actuaciones cuya remisión ordena el artículo 36, la posición de dichas partes acerca de la constitucionalidad de la ley, puesta de manifiesto en el trámite de audiencia del artículo 35.2. El problema surge si una de las partes tiene ex lege acceso al proceso constitucional y la otra u otras no. El Tribunal Constitucional, empero, rechazó reiteradamente que hubiera entonces indefensión para las personas físicas o jurídicas cuyos intereses pudieran verse afectados por la sentencia pronunciada en la cuestión de inconstitucionalidad, ya que esa sentencia «es el resultado... de un proceso estrictamente objetivo en el que en ningún caso pueden hacerse valer derechos subjetivos o intereses legítimos» (véanse los AATC 378/1993, FJ 1 y 2, y 174/1995, FJ 3, que recogen la doctrina del Tribunal desde el ATC 132/1983). Ahora bien, la perspectiva del asunto cambió con la Sentencia del Tribunal Europeo de Derechos Humanos de 23 de junio de 1993 (caso Ruiz Mateos contra España). En ella se constata, en primer lugar, que la anulación por el TC de la Ley de expropiación de RUMASA hubiera llevado a la jurisdicción ordinaria a estimar las pretensiones de la familia Ruíz Mateos (§ 59), y, en segundo lugar, que dicha Ley concernía directamente a un círculo restringido de personas, por lo que, en el proceso constitucional, había que garantizar a tales personas el libre acceso a las alegaciones de las otras partes y una verdadera posibilidad de combatirlas (§ 63). El Abogado del Estado había for- 
mulado alegaciones en el proceso constitucional en pro de la constitucionalidad de la ley cuestionada, a las cuales los Ruíz Mateos no tuvieron ocasión de responder, a pesar de su interés en poder hacerlo antes de la decisión final (§ 65). Según el Gobierno español, el TC estuvo en condiciones de estudiar las alegaciones de los Ruíz Mateos a través de los escritos, muy extensos, que habían presentado en el trámite de audiencia del artículo 35.2 LOTC, pues le había sido remitido el testimonio completo de aquéllos (§ 66). Pero este argumento no convenció al TEDH, dado que el citado precepto legal prevé el otorgamiento de un plazo «común» de alegaciones, de manera que los Ruíz Mateos no podían conocer las formuladas por el Abogado del Estado, en tanto que éste, en el proceso constitucional, conocía de antemano las suyas y pudo combatirlas ante el TC (§ 67). Hubo, pues, infracción del artículo 6.1 del CEDH, en cuanto al carácter equitativo del proceso constitucional.

Pues bien, ante un nuevo supuesto de cuestión de inconstitucionalidad planteada respecto de una ley singular, la STC 48/2005 entendió que, en atención a la doctrina del TEDH, los destinatarios de dicha ley deberían haber sido parte del proceso constitucional. Sin embargo, el tenor literal del artículo 37.2 LOTC «es aún hoy el que era cuando se dio lugar a aquella Sentencia del Tribunal Europeo» (la del caso Ruíz Mateos). Ello no supone que no sea posible flexibilizar el tenor de la LOTC «cuando así lo impongan consideraciones inaplazables de defensa de los derechos fundamentales, en particular cuando su infracción ha sido formalmente constatada» por el TEDH. Con todo, precisa el TC, la vinculación a la LOTC «requiere que, en tanto no se articule ante nosotros una pretensión específica de adecuación a lo que resulta de la jurisprudencia europea, sólo si los interesados hubieran pretendido la personación en este procedimiento, deberíamos haber arbitrado el cauce procesal necesario» (FJ 2). Este esfuerzo de adaptación a la doctrina del TEDH en los supuestos de leyes singulares es ya superfluo con la reforma de la LOTC por la Ley Orgánica 6/2007, que, yendo más allá de tales supuestos — pero afirmando, no obstante, en su Exposición de Motivos, seguir las directrices de la STDH de 23 de junio de 1993 - responde adecuadamente a la exigencia de igualdad de armas procesales en el procedimiento ante el órgano judicial a quo que se deriva del artículo 6.1 del CEDH.

El artículo 49.1 LOTC dispone, a partir de la reforma de 2007, que «en todo caso, la demanda (mediante la que se inicia el recurso de amparo) justificará la especial trascendencia constitucional del recurso». Así, la admisión de los recursos de amparo se hace depender, además del cumplimiento de los requisitos procesales legalmente establecidos, de que su contenido «justifique una decisión sobre el fondo por parte del Tribunal Constitucional en razón de su especial trascendencia constitucional, que se apreciará atendiendo a su importancia para la interpretación de la Constitución, para su aplicación o para su general eficacia, y para la determinación del contenido y alcance de los derechos fundamentales» (art. 50.1 br). La pretensión del legislador, según explicó él mismo, fue aliviar «la sobrecarga que en la actualidad sufre el Tribunal a la hora de resolver estos procedimientos de garantía de los derechos fundamentales». A tal efecto «se invierte el juicio de admisibilidad, ya que se pasa de comprobar la inexistencia de causas de inadmisión a la verificación de la existencia de una relevancia constitucional en el recurso de amparo» (Exposición de Motivos de la L.O. 6/2007).

Lo primero que llama la atención en esta muy importante reforma de la LOTC es la disociación entre efectiva lesión de un derecho fundamental y viabilidad de un recurso de 
amparo. Como se declara paladinamente en el ATC 188/2008, «la carga de justificar la especial trascendencia constitucional del recurso de amparo es algo distinto a razonar la existencia de la vulneración de un derecho fundamental» (FJ 2). Y en la STC 155/2009, aparte de respaldar la opción del legislador (como ejercicio de la habilitación que constitucionalmente le confiere el art. 161.1 b) CE, en relación con su art. 53.2) por una nueva configuración del recurso de amparo, el Tribunal precisa que, «en principio (sic), tras la reforma llevada a cabo la mera lesión de un derecho fundamental o libertad pública tutelable en amparo ya no será por sí sola suficiente para admitir el recurso, pues es imprescindible, además, su <especial trascendencia constitucional >, frente a la configuración por la que esencialmente se caracterizaba en su anterior regulación, en tanto que recurso orientado primordialmente a reparar las lesiones causadas» en aquellos derechos. «El recurso de amparo, en todo caso, sigue siendo un recurso de tutela de derechos fundamentales», si bien la garantía de los mismos se encomienda a los órganos judiciales como sus «guardianes naturales y primeros», culminándose el sistema de protección por el TC, que, además de garante último de tales derechos, es su máximo intérprete (arts. 53.2 CE y 1.1 LOTC) (FJ 2). ¿Cuándo procederá adoptar, de acuerdo con el artículo 50.1 b) LOTC, una decisión sobre el fondo en razón de la especial trascendencia constitucional del recurso? El Tribunal enumera en esa misma STC 155/2009 una relación —abierta y susceptible de ampliación y revisión — de supuestos posibles, casi todos atinentes a la fijación y cumplimiento de la doctrina jurisprudencial constitucional.

El recurso de amparo ve, pues, debilitada su predominante dimensión subjetiva y reparadora y se acerca a la conformación de una casación constitucional (compárese esto con lo proclamado en sentido contrario por la STC 114/1995, FJ 2), dejándose a los órganos judiciales ordinarios la tarea de ser los guardianes «naturales» de la efectividad de los derechos fundamentales, lo que adicionalmente se refuerza a través de la modificación, también mediante la L.O. 6/2007, del artículo 241.1 de la Ley Orgánica del Poder Judicial. Como señala la Exposición de Motivos de la Ley reformadora, ésta efectúa «una configuración del incidente de nulidad de actuaciones mucho más amplia, porque se permite su solicitud con base en cualquier vulneración de alguno de los derechos fundamentales referidos en el artículo 53.2 de la Constitución, en lugar de la alegación de indefensión o incongruencia prevista hasta el momento».

Por lo que respecta a la valoración de esta reforma, siempre observé con preocupación la denominada «objetivación» del recurso de amparo constitucional, tanto si la relevancia en orden a la admisibilidad de los recursos se vinculaba al interés doctrinal del asunto como si se hacía depender de la gravedad de los perjuicios irrogados al demandante (esto segundo es lo que, dada la escasa cuantía litigiosa del pleito judicial, hizo sin cobertura legal el ATC 248/1994, v.g.). En mi criterio, pues, la admisión de la demanda de amparo habría de resultar procedente siempre que se apreciase la vulneración de un derecho fundamental del recurrente. Acepto, sin embargo, plenamente el desiderátum que una vez formulara, no sin escepticismo, J.L. Requejo Pagés al abogar por «un sistema de protección de los derechos fundamentales en el que se conjugaran, en síntesis perfecta, las vertientes subjetiva y objetiva, esto es, en el que el fin de la salvaguardia objetiva del elenco de derechos se cohonestara, sin zonas oscuras, con la defensa de los intereses subjetivos de los justiciables». Mas, sea como fuere, y habiéndose modificado la LOTC tan radicalmente en sentido objetivo, ¿ha valido la pena? No creo que la respuesta 
haya de basarse meramente en datos estadísticos, a pesar de los fines explícitamente perseguidos por el legislador de la reforma, sino en la capacidad directiva y orientadora de los pronunciamientos doctrinales del TC y su influencia sobre la acción de los distintos poderes del Estado, señaladamente sobre una judicatura que, ciertamente, tiene ante sí un amplio corpus dogmático elaborado a lo largo de tres décadas por el supremo intérprete de la Constitución, sin olvidar la creativa jurisprudencia del TEDH. Todavía es pronto (sólo han transcurrido cuatro años desde la entrada en vigor de la disposición reformadora) para hacer balance cuantitativo y, más aún, cualitativo. Si consultamos la última Memoria del Tribunal, nos encontraremos con esta secuencia de providencias de inadmisión dictadas en recursos de amparo: 7.370 en 2006, 10.884 en 2007, 12.396 en 2008, 13.008 en 2009 y 8.964 en 2010. ¿Quiere ello significar que, por fin, en el último año citado los abogados comenzaron a asimilar el nuevo carácter del recurso de amparo, así como la obligación de utilizar el cauce del nuevo artículo 241.1 LOPJ para agotar la vía judicial previa?

Finalmente, resulta destacable la nueva regulación de la llamada «autocuestión»o cuestión «interna» de inconstitucionalidad. De forma técnicamente más correcta que la redacción originaria del artículo 55.2 LOTC, dicho precepto prevé ahora que la autocuestión se plantee por la Sala o la Sección antes de dictar sentencia. El control incidental de la constitucionalidad de la ley permite, así, la congruencia lógica entre la sentencia de amparo (posterior) y la pronunciada previamente en la cuestión interna, evitándose las situaciones de desautorización inherentes a los fallos desestimatorios del Pleno (como, v.g., el de la STC 185/1990, que declaró no contrario a la Constitución el precepto cuestionado por la Sala, la cual ya había emitido sentencia estimatoria del amparo «porque la ley aplicada, según rezaba a la sazón el art. 55.2 LOTC, lesiona derechos fundamentales o libertades públicas»).

\section{Juan Alfonso Santamaría Pastor}

Entiendo que la cuestión se refiere exclusivamente a la introducción que la Ley orgánica 6/2007 hizo de un nuevo párrafo segundo en el artículo 16.1 de la LOTC (comentar el resto de las numerosas y fundamentales modificaciones que dicha Ley orgánica introdujo en los diferentes procesos constitucionales sería inviable en el marco de esta encuesta).

La innovación no me pareció en su momento inadecuada, ni me lo parece ahora, aunque su desarrollo sea mejorable. En primer lugar, atribuir a los parlamentos autonómicos la propuesta de los candidatos no supone un completo desapoderamiento del Senado, el cual siempre conservaría el poder de rechazar a cualesquiera candidatos (al menos, teóricamente); la Constitución atribuye al Senado el poder de designación, pero no prejuzga la forma o el canal de propuesta de los candidatos que, por tanto, podría ser éste o cualquier otro. Pero, además, la discusión acerca de si la vía de propuesta de candidatos ha de ser necesariamente o no la de los grupos parlamentarios, como sucedió hasta la reforma que comentamos, es puramente académica, habida cuenta de que el sistema de partidos opera de forma transversal en el Estado y en las Comunidades Autónomas: así lo demuestra la nada sorprendente coincidencia que se ha producido en la última renovación 
que ha tenido lugar, en la que bastantes de las Asambleas Legislativas autonómicas dominadas por un partido u otro han propuesto al mismo candidato.

En este contexto, la reforma tiene, creo, mucho de cosmética. Simbólicamente es importante, en cuanto marca un hito más en la progresiva «autonomización» de las instituciones centrales del Estado, y constituye un nuevo intento en el vano empeño de hacer realidad la aspiración constitucional de que el Senado sea una auténtica Cámara de representación territorial. Pero, en tanto el sistema de partidos funcione en España como lo hace en la actualidad, la reforma no va a tener efecto sensible alguno; suponer que cuatro miembros del Tribunal Constitucional van a ser designados por las Comunidades Autónomas es sencillamente falso.

El precepto, sin embargo, me parece insuficiente, así como el parco desarrollo que hizo del mismo el artículo 184.7 del Reglamento del Senado. Este apunta en la buena dirección, al establecer que cada Asamblea Legislativa podrá presentar «hasta dos candidatos»; pero hubiera sido preferible, en aras de la (aparente) objetividad de la Cámara proponente, que se hubiera exigido, al menos, la presentación de al menos dos candidatos, uno por la mayoría y otro por la minoría mayoritaria en ella. Sin duda, ello no alteraría el resultado final de la designación/elección por el Senado: pero, al menos, evitaría la mala imagen de que el propuesto por el parlamento autonómico aparezca, salvo en casos de consenso, como el candidato del partido mayoritario en el mismo.

En cualquier caso, esta concesión al autonomismo no puede satisfacer un elemental principio de equilibrio. Siempre me ha parecido incorrecto el derecho de cada comunidad autónoma, proclamado en todos los Estatutos de Autonomía desde 1981, a participar en el nombramiento de los miembros de órganos estatales, sin previsión alguna recíproca: no parece en modo alguno desproporcionado imaginar que las Cortes Generales debieran poder, por ejemplo, proponer algún candidato para constituir el Consejo de Garantías Estatutarias de la Generalidad de Cataluña. Pero la deriva unilateral hacia el autonomismo que ha experimentado el sistema político español hace inviables tales planteamientos, que sería inútil tomar siquiera en consideración.

4. ¿Nos podría dar su opinión respecto a la reforma del apartado 3 del art. 16 LOTC en lo que respecta a la «prorrogatio» del presidente y del vicepresidente?

\section{Luis Aguiar De LuQue}

Me parece no sólo conforme a la Constitución, como ha proclamado la ya citada STC 49/2008, sino absolutamente lógica y operativa para el funcionamiento del Tribunal. El hecho de que sin existir tal previsión legal dicha «prorogatio» haya venido operando en la práctica.

Cuestión distinta es que esa «prorogatio» haya devenido insuficiente para poder dar respuesta al práctico solapamiento de retrasos en la renovación de dos bloques de magistrados que se ha producido recientemente (correspondientes al Senado y al Congreso respectivamente) a consecuencia del incumplimiento por el Congreso de los Diputados del plazo constitucionalmente establecido para renovar el Tribunal. Pero el problema entonces, no deriva de la modificación legal de la duración del mandato de presidente y vi- 
cepresidente, sino de la irregular e inusitada situación creada por las instancias a quienes correspondía propiciar los nuevos nombramientos de magistrados. Pero de ello me ocuparé en la siguiente pregunta.

\section{Francisco Javier Díez Revorio}

Se trata de otra de las novedades significativas de la reforma de 2007, que permite en síntesis que el presidente y el vicepresidente que entren, como magistrados del Tribunal Constitucional, en situación de prorrogatio, puedan mantener durante la misma su situación de presidente y vicepresidente del Tribunal. En mi opinión, es incuestionable el dato de que la reforma viene en este punto simplemente a plasmar lo que ya era una práctica habitual antes de la misma; pero también parece claro que la introducción de esta novedad normativa en el art. 16.3 tenía como propósito específico intentar asegurar una sentencia más favorable al Gobierno en el ya varias veces citado asunto del Estatuto de Cataluña, rompiendo un empate previsible en aquel momento con el voto de calidad.

En cualquier caso, y con independencia de que la solución introducida sea una de las posibles y tenga sus ventajas, su plasmación escrita supuso el reconocimiento legal de una práctica claramente alejada de la Constitución, como es la ausencia de renovación de los magistrados transcurridos nueve años desde su nombramiento. De esta manera, se da carta de naturaleza legal a una irregularidad que no debería producirse en ningún caso, y que como antes apuntábamos ha sido uno de los factores más significativos en la actual crisis de prestigio del Tribunal.

\section{Alfonso Fernández Miranda}

Ver las respuestas dadas a la pregunta número 3.

\section{VicENTE GIMENO SENDRA}

La prórroga del Presidente y del Vicepresidente era un uso forense del Tribunal Constitucional que la L.O. 6/2007 elevó a norma.

\section{JAVIER PÉREZ RoYO}

La reforma no se habría producido si no fuera porque, en el momento en que se hizo, el Tribunal Constitucional tenía que resolver el recurso de inconstitucionalidad contra la reforma del Estatuto de Autonomía para Cataluña. A nadie se le habría ocurrido, sin dicho recurso de inconstitucionalidad, poner en cuestión la convención seguida sin interrupción hasta el momento de la «prorrogatio» del presidente y vicepresidente y, en consecuencia, a nadie se le habría ocurrido tampoco convertir la convención en norma escrita. 
Un indicador más de lo disparatado que ha sido la tramitación del recurso de anticonstitucionalidad contra la reforma del Estatuto de Autonomía para Cataluña ante el Tribunal Constitucional.

\section{RAMÓN PUnSET BLANCO}

Comparto en este punto la opinión de la mayoría de los Magistrados del TC reflejada en la Sentencia 49/2008 (FJ 18 a 21). Añadiría, sin embargo, otro argumento favorable a la previsión legal de prórroga del mandato del Presidente y del Vicepresidente del Tribunal hasta que se produzca la renovación parcial del órgano. Dije antes, al responder a la primera pregunta de esta encuesta, que el TC es un órgano de origen electivo, no representativo, queriendo destacar así su independencia frente a los propios órganos constitucionales que periódicamente han de proceder a su renovación por tercios, independencia que impide cualquier responsabilidad ante tales órganos. Ese carácter electivo y la temporalidad del mandato de los Magistrados son, no obstante, disposiciones del constituyente que persiguen alcanzar una cierta representatividad, y con ella el acceso a la jurisdicción constitucional del sistema de valores dominante en la sociedad, que de este modo vivifica la hermenéutica de la Constitución cuando la naturaleza y estructura de sus preceptos lo autoriza (en otro caso el TC ha de dejar patente que la satisfacción de las nuevas aspiraciones sociales sólo es posible mediante la reforma constitucional). De ahí, a mi juicio, que la Presidencia y Vicepresidencia del Tribunal tengan un mandato en todo coincidente con la composición del Pleno que los ha elegido, y por eso considero acertada la distinción entre ese mandato y la prórroga del mismo hasta que el TC sea renovado. No hay en este criterio el menor asomo de «política institucional», sino una determinada inteligencia de la configuración constitucional del Alto Tribunal.

\section{Juan Alfonso Santamaría Pastor}

Con independencia de las singulares circunstancias que provocaron la reforma (que probablemente la desautorizan por completo), el régimen de prorogatio del Presidente y Vicepresidente del Tribunal que establece el nuevo articulo 16.3 de la LOTC no me parece afortunada.

No parece muy lógico, en efecto, que el Tribunal elija a un Presidente y un Vicepresidente cuando un tercio de sus miembros tienen caducados sus mandatos, imponiéndose esta elección a los nuevos Magistrados que sean posteriormente designados. Ciertamente, podría procederse a tal elección, y repetirse a la fecha de toma de posesión de los nuevos Magistrados; pero ello no sería adecuado a la estabilidad temporal que debe ofrecer el ejercicio de estos cargos.

La solución, en suma, no es buena: no cabía esperar otra cosa del hecho de ser una solución pensada para salir al paso de la anomalía de los imperdonables retrasos producidos en la renovación de los miembros del Tribunal. El que, además, se haya establecido en la ley precisamente en un momento de prórroga de mandato y pendientes de fallo recursos tan polémicos como los planteados contra el Estatuto de Cataluña no ha podido 
ser más inoportuno, en cuanto ha dado lugar a todo tipo de sospechas de manipulación por parte del Gobierno y de manifiesta parcialidad de la Presidente prorrogada; que ha sido la primera víctima de una ocurrencia legislativa que debería haberse dejado para mejor ocasión.

5. Y lo preceptuado en el apartado 3 del propio art. 159 CE sobre que los miembros del Tribunal «serán designados por un período de nueve años y se renovarán por terceras partes cada tres» ¿Qué fuerza de obligar debería tener para los correspondientes poderes constituidos a los que está encomendada la propuesta al Rey de los nuevos miembros del Tribunal? En conexión con lo anterior ¿Cree Vd. que la ratio del art. 17 LOTC está siendo bien desplegada por quienes tienen que aplicarlo? ¿Propondría Vd. la modificación del precepto o sólo la de sus prácticas aplicativas? Más en concreto, ¿Qué sugerencias haría Vd. sobre cómo deberían comportarse los grupos parlamentarios al asumir sus responsabilidades al respecto?

\section{Luis AguiAr DE LUQUE}

Desde un punto de vista jurídico-constitucional me quedan pocas dudas acerca de la fuerza vinculante y vocación de obligar del enunciado del art. 159.3 de la Constitución. Forma parte del contenido de la Constitución a la que por mandato constitucional están sujetos ciudadanos y poderes públicos, su pretensión es claramente prescriptiva como acredita el empleo en dos ocasiones de la forma verbal imperativa («serán designados» y «se renovarán») y su dicción es precisa, taxativa y completa, en particular al verse complementada por la Disposición Transitoria $9^{a}$ que especifica el modo de llevar a la práctica sus previsiones. Consecuentemente el prolongado incumplimiento de las obligaciones que dicho precepto prescribe, algo que a mayor abundamiento parece haber devenido en práctica habitual cuando la formulación de propuestas corresponde al Congreso y al Senado, entiendo que solo puede ser calificado como una flagrante y patente vulneración de la Constitución.

Cuestión distinta son las indudables dificultades que plantea el intentar determinar las causas de tales demoras, así como, en función de ello, pretender asignar responsabilidades (en sentido jurídico y en sentido político) por dicho incumplimiento de deberes constitucionales. Y tampoco creo que sea posible adoptar medidas de tipo jurídico que puedan paliar en la actualidad, y evitar que se reproduzcan en el futuro, este tipo de conductas omisivas. Solo un serio y responsable compromiso por parte de las fuerzas parlamentarias más relevantes, que busque recuperar el hoy perdido sentido institucional de las mismas, podrá resolver la situación actualmente planteada y evitarlas nuevamente en el futuro.

A tenor de lo dicho hasta aquí, resulta innecesario advertir que las actitudes viciadas de inconstitucionalidad, que en la pregunta se califican como "prácticas aplicativas», serían las que precisan ser revisadas, modificación que difícilmente puede propiciarse desde reformas legales «ad hoc».

Por las mismas razones creo que, pese a la irrelevancia de las previsiones contempladas en el art. 17.1 de la LOTC en su redacción actual, tampoco la reforma de dicho 
precepto podría dotar de mayor fuerza jurídica de la que ya tienen a las prescripciones del art. $159.3 \mathrm{CE}$.

$\mathrm{Y}$ en cuanto a la controvertida «prorogatio» de funciones que establece el art. 17.2 de la LOTC, algún significado administrativista igualmente participante en esta Encuesta (me refiero al profesor J. A. Santamaría), atribuyó — como es sabido— a dicha institución un cierto papel incentivador de los retrasos en las renovaciones de los principales órganos constitucionales. Pues bien, más allá de alguna puntual discrepancia personal con dicha tesis, ciertamente la supresión de la «prorogatio» podría servir - llegado el caso- para evidenciar aun más la situación crítica en que podría encontrarse nuestro sistema de jurisdicción constitucional (y por extensión el régimen constitucional en general) a causa de las reiteradas demoras en las renovaciones del Tribunal. Pero nuestros grupos parlamentarios en general (y alguno más que otro en particular), no parecen ser sensibles a este tipo de presión, ni especialmente preocupados por la pérdida de credibilidad que pueda sufrir una institución capital para el correcto funcionamiento de nuestro régimen constitucional. La falta de una respuesta mínimamente solvente a la llamada de atención efectuada desde el seno del propio Tribunal Constitucional mediante la presentación de la dimisión por tres magistrados constitucionales y la no aceptación de la misma por su Presidente, pone en evidencia el desdén con la que se contempla este problema en sede parlamentaria.

En este sentido creo que tanto desde los sectores académicos, como desde la opinión pública, lo único que se puede reivindicar es un mayor sentido institucional de los grupos parlamentarios (en particular de alguno de ellos que obstaculiza la renovación con argumentos insostenibles en términos constitucionales), pues es en ese terreno, y no mediante reformas legales, donde el problema debe situarse y encontrar solución.

\section{Francisco Javier Díez Revorio}

La Constitución dice que los magistrados del Tribunal Constitucional son designados para un período de nueve años y se renovarán por terceras partes cada tres años. Por tanto toda norma o toda situación contraria a ese mandato es inconstitucional, de manera que ningún magistrado debería permanecer en el cargo más de nueve años (con las únicas excepciones a las que luego me referiré), y las renovaciones deberían producirse siempre cada tres años estrictos.

El artículo 17 LOTC trata en su apartado primero de introducir las previsiones necesarias para el cumplimiento del mandato constitucional, iniciando el proceso de renovación cuatro meses antes de vencimiento del mandato, mediante la notificación prevista por el presidente del TC al presidente de la institución que ha de proponer a los nuevos magistrados.

Ciertamente, el apartado segundo del mismo precepto establece que los anteriores magistrados continuarán en el ejercicio de sus funciones hasta la toma de posesión de los nuevos. Pero de esta previsión no se deduce necesariamente la posibilidad de un retraso en la propuesta de los nuevos (puede tratarse de que los nuevos magistrados ya propuestos tarden algunos días en tomar posesión), y aunque el legislador estuviera contem- 
plando esta hipótesis, es claro que la previsión legal sería de retrasos en días o semanas, y no desde luego de períodos más largos. En cualquier caso, cabe reiterar que el retraso en la renovación es constitucionalmente ilegítimo; y que obviamente la situación será tanto más grave cuanto mayor sea la dilación, de manera que una demora de años, como la que se ha llegado a producir, es absolutamente rechazable por su manifiesta contrariedad a la Constitución. Y por lo demás, también lo será cualquier interpretación del artículo 17.2 que legitimase tal retraso.

De todas formas creo preferible una reforma de dicho artículo que procediera exactamente a la regulación contraria, esto es, a eliminar la prorrogatio, en el sentido que más tarde explicaré.

\section{Alfonso Fernández Miranda}

Ver las respuestas dadas a la pregunta número 3.

\section{VICENTE GIMENO SENDRA}

El sistema de renovación del Tribunal Constitucional me parece correcto, pues obvia las mutaciones traumáticas que pudieran surgir como consecuencia del triunfo electoral del partido que se encontraba en la oposición. Lo que me parece un incumplimiento de la Constitución, una manipulación del Juez legal constitucional y un desprecio hacia los Magistrados del Tribunal Constitucional es el retenerlos «sine die» hasta que los partidos políticos mayoritarios decidan a su antojo la renovación.

\section{JAVIER PÉREZ Royo}

Creo que tanto el artículo 159.3 CE como el 17 LOTC están bien redactados, son fáciles de interpretar y su aplicación no debería deparar problema de ningún tipo.

Quiero decir con ello que no es mediante una reforma de dichos artículos como se puede resolver el problema de la renovación parcial del Tribunal Constitucional, que no ha dejado de plantearse en ninguna de las renovaciones por parte del Congreso de los Diputados o del Senado, aunque cada vez con más intensidad.

El problema es un problema de fondo que deriva de la incapacidad que tienen los dos grandes partidos españoles, PP y PSOE, para llegar a ningún tipo de acuerdo en asuntos constitucionales. Esa incapacidad es absoluta en lo que a la reforma de la Constitución se refiere y está llegando a ser casi absoluta en lo que a la renovación de los órganos constituciones, Tribunal Constitucional, Consejo General del Poder Judicial y Defensor del Pueblo, afecta.

De la incapacidad absoluta respecto de la reforma derivan las incapacidades casi absolutas respecto de la renovación de estos órganos constitucionales. En todos los casos se exige la misma mayoría cualificada. Y en todos resulta imposible alcanzarla de una manera normal. 
Esto no puede ser resuelto mediante ingeniería constitucional. Me temo mucho que cualquier mecanismo que se diseñara podrá acabar diciendo que el remedio es peor que la enfermedad.

\section{RAMÓN Punset BlanCO}

La no renovación en plazo de los Magistrados del TC se ha convertido en un problema crónico cada vez que la decisión compete a una de las Cámaras de las Cortes Generales. Se trata, dije antes, de una manifestación palmaria de deslealtad constitucional, aunque, por si ese concepto no pareciera suficientemente jurídico (que lo es), conviene precisar más y señalar que estamos ante la infracción reiterada de una norma constitucional, el artículo 159.3 de la Ley Fundamental. Tanto el Presidente del TC como los Presidentes del Congreso y del Senado suelen realizar — con gesto grave y dignidad patricia - apelaciones dramáticas a los Grupos Parlamentarios mayoritarios en orden al cumplimiento del citado precepto constitucional. Recientemente hemos asistido incluso a la escenificación de la dimisión fallida de tres Magistrados, destinada a conmover, hasta ahora sin éxito, a los Grupos Socialista y Popular del Congreso. La mayoría de tres quintos exigida por el artículo 159.1 CE para la elección parlamentaria de los Magistrados del TC, en lugar de propiciar el consenso pretendido por el constituyente, ha derivado en una práctica de bloqueo por parte del principal Grupo de la oposición, expectante ante un más o menos inminente vuelco electoral que le permita disponer de una cuota mayor de influencia en la integración del Tribunal.

Pues bien, siendo indudablemente gravísimo este constante e impune quebrantamiento de la Constitución (que además se extiende también a la elección del Consejo General del Poder Judicial, el Defensor del Pueblo y el Tribunal de Cuentas), sorprende la falta de intervención al respecto del Jefe del Estado, quien, según el artículo 56.1 CE, «arbitra y modera el funcionamiento regular de las instituciones». Este poder de reserva del Rey se traduce en una función dinamizadora del sistema constitucional, de coordinación última de los órganos situados en el vértice del ordenamiento y de desbloqueo institucional.

\section{Juan Alfonso Santamaría Pastor}

Esta cuestión plantea un numeroso conjunto de interrogantes, que deben examinarse por separado.

\section{Sobre la fuerza de obligar del mandato constitucional de renovación trienal.}

Con todo respeto, la pregunta me parece escasamente relevante. Fuerza de obligar, en abstracto, la tiene toda, supuesto el indiscutible carácter normativo que la Constitución posee; pero sanción, ninguna, puesto que no existe instancia ni vía procesal hábil en nuestro ordenamiento jurídico para ejercer coerción sobre las Cámaras legislativas (tampoco sobre las autonómicas, en su propuesta de candidatos) ni sobre el Gobierno para que procedan a la renovación en plazo. La presión de la opinión pública se ha mostrado tam- 
bién insuficiente para forzar a las direcciones centrales de los partidos a llegar a un consenso.

La renovación en plazo de los Magistrados del Tribunal no es, por tanto, una cuestión que pueda plantearse ni resolverse en el terreno jurídico. Como tantas otras decisiones que los órganos constitucionales deben adoptar (la sanción de las leyes, o la convocatoria de elecciones), su cumplimiento es un asunto de cultura política, no de leyes ni tribunales.

Por supuesto, el ordenamiento podría establecer medios indirectos de coerción para que los partidos cumpliesen el plazo con este deber constitucional, y alguno de ellos se ha deslizado en los medios de opinión (por ejemplo, que los Diputados y Senadores, y los miembros del Gobierno, no percibieran sus retribuciones o asignaciones a partir de la fecha límite en que los nombramientos debían haber sido efectuados); pero estas soluciones constituyen propuestas netamente arbitristas, por irreales, por lo que no merecen consideración alguna.

\section{Sobre la redacción y posible reforma del artículo 17 LOTC.}

Habida cuenta del contexto general de la cuestión quinta de la encuesta, doy por supuesto que la cuestión se refiere sólo al apartado 1 del artículo, no a la previsión de prorogatio (apartado 2).

En su redacción inmodificada, el precepto es razonable, aunque un tanto ocioso, ya que las fuerzas políticas no precisan de recordatorio formal alguno para proceder a poner en marcha cuestión tan relevante como la renovación parcial del Tribunal. Quizá el plazo de cuatro meses de antelación se ha revelado excesivamente corto, vistas las crecientes dificultades en que se han encontrado los partidos para llegar a un consenso. Pero no se trata de una cuestión fundamental, porque poco se ganaría con una ampliación de este plazo.

¿Surtiría algún efecto práctico una reforma que constriñese de alguna forma a los partidos/grupos parlamentarios a proceder a la renovación en plazo? Tengo serias dudas de ello. Por ejemplo, podría reformarse la Ley en el sentido de decir que la propuesta de candidatos se incluirá necesariamente en el orden del día de la sesión que la Cámara respectiva celebre un mes antes de la fecha límite de renovación; o, como se hizo hace años en la regulación del Bundesverfassungsgericht, ordenando al propio Tribunal, en caso de retraso de las Cámaras, a hacer llegar a éstas una propuesta de candidatos con un número de nombres superior al de Magistrados que hayan de ser elegidos, sobre la que la Cámara habría de pronunciarse imperativamente en un plazo breve (pudiendo elegir, por supuesto, a personas distintas de las incluidas en la lista); pero nada impediría que tales incentivos fueran pasados por alto de la misma forma en la que se incumple el propio precepto constitucional, sin que exista medio alguno de coacción o sanción eficaz contra esta inobservancia. La cuestión, nuevamente, es de cultura política (o, como dice el cuestionario, de prácticas aplicativas), no de medios jurídicos.

\section{Sobre el comportamiento de los grupos parlamentarios.}

La última cuestión, relativa a las posibles sugerencias acerca de cómo deberían comportarse los grupos parlamentarios en todo el proceso de renovación, no tiene res- 
puesta fácil; o la tiene, paradójicamente, demasiado sencilla. Como cuestión que es de cultura política, el comportamiento de los grupos parlamentarios debería ser el de asumir la conciencia y decisión plenas de que los plazos que la Constitución establece en estos trámites de renovación de órganos constitucionales no pueden incumplirse bajo ningún concepto; como sucede con toda normalidad en otras actuaciones no menos trascendentes, como la convocatoria de elecciones generales o la sucesiva investidura del Presidente del Gobierno.

Ir más allá no sólo sería infructífero, sino incluso desaconsejable.

6. A su juicio ¿es inconstitucional que se acumulen en un mismo momento las propuestas de nombramientos de más de un tercio — por ejemplo, dos tercios — de los miembros del Tribunal Constitucional? ¿Y podría Vd. hacernos algunas consideraciones sobre la reforma de la LOTC, mediante LO 8/2010, de 4 de noviembre?

\section{Luis Aguiar De LUQUe}

Para realizar una valoración más ajustada de la reforma de la LOTC llevada a cabo por la LO 8/2010, creo que es preciso retomar de nuevo el contenido del art. 159.3 CE y examinar su contenido en cierta medida contradictorio. Me refiero concretamente a la renovación por tercios homogéneos de magistrados constituidos en función del origen del nombramiento de un lado, y la duración del mandato acotado a 9 años de otro, pues en el momento en que el mandato de un magistrado se interrumpa antes del plazo constitucionalmente previsto, de modo singular y por causas excepcionales (dimisión, fallecimiento, etc), o bien se quiebra la renovación homogénea del tercio afectado, o bien se ha de aceptar que la duración de determinados mandatos se vea irremediablemente reducida a un periodo inferior al previsto en el art. 159.3.

Ante dicha disyuntiva, la lógica parece aconsejar que prevalezca la duración constitucional del mandato de los magistrados. No solo por el carácter más explícito de su enunciado, sino también porque parece ser ésta una opción del constituyente de mayor entidad y significado que la renovación por tercios homogéneos. Más aún, no han faltado comentaristas, en mi opinión con buen criterio, que se han manifestado a título de principio en favor de mantener en todo caso la duración de nueve años del mandato de todos y cada uno de los magistrados, aunque ello supusiera un mayor fraccionamiento de las propuestas de nombramientos, entendiendo que esto último dificultaría el fenómeno de «lotización» o reparto de las propuestas entre los grupos parlamentarios participes del acuerdo. Sin embargo no ha sido esa la práctica que se ha seguido desde los primeros años de funcionamiento del Tribunal, probablemente porque la propia LOTC, al prever indirectamente en su art. 16.4 que el nombramiento de los magistrados constitucionales pueda tener de hecho una duración inferior a nueve años («Ningún Magistrado podrá ser propuesto al Rey para otro periodo inmediato, salvo que hubiera ocupado el cargo por un plazo no superior a tres años»), daba por sentado que, entre los dos criterios indicados, debía prevalecer la renovación por tercios homogéneos. 
Pues bien, la reforma legal introducida por la LO 8/2010 se decanta explícitamente por la prevalencia del nombramiento de magistrados por bloques homogéneos respecto a la duración temporal del mandato (que en el art. 16.4 aparecía solo implícita) y aprovecha esa explicitación para dar rango legal a los retrasos en las renovaciones ( «Si hubiese retraso en la renovación por tercios de los Magistrados...»). Al parecer con la finalidad de evitar que se pudiera producir en un corto periodo de tiempo la acumulación de propuestas de más de uno de los bloques (con toda probabilidad los tercios correspondientes al Senado y al Congreso), tal como parecía que se iba a producir en los últimos meses del año 2010, lo que cronificaría pro futuro un modo de renovación que no se adecúa a la previsión constitucional de renovación por tercios.

Sin embargo la respuesta del legislador a esta última eventualidad, aunque pueda ser constitucionalmente correcta por los fines perseguidos (asegurar la renovación por tercios que consagra el art. 159.3 CE) resulta en mi opinión excesivamente condicionada por la coyuntural situación de ese momento, poco meditada (lo que puede producir paradójicos resultados en el futuro) y traslada a la ciudadanía un mensaje un tanto peculiar acerca de cómo cumplir con las obligaciones que la Constitución impone a los poderes públicos.

Por un lado, dicha reforma petrifica unas fechas de renovación que son exclusivamente fruto de unas circunstancias fortuitas producidas tres, seis y nueve años antes y no obedecen a ningún criterio preconcebido. A partir de la entrada en vigor de la reforma, la renovación del Tribunal deberá necesariamente llevarse a cabo cuando se cumplan 9 años del 7 de noviembre del 2010 para los nombrados por el Congreso de los Diputados (sea cual sea la fecha en que se produzca la renovación actualmente pendiente), 8 de junio del 2013 para los nombrados por el Gobierno y el CGPJ) y 16 de diciembre de 2016 (para los que fueron nombrados a propuesta del Senado el 29 de diciembre de 2010), lo que en la práctica va a dotar de una elasticidad a la duración del mandato de los magistrados constitucionales, que en absoluto estaba prevista por el constituyente. Y lo que es más grave unas sensibles e injustificables diferencias entre la duración del mandato de unos y otros en función del órgano proponente, pues todo hace suponer que solo el tercio nombrado por Gobierno y el CGPJ se adecuará a lo previsto en el art. 159.3 CE.

Con todo, lo que me parece más preocupante de dicha reforma es el mensaje —un tanto singular - que subliminarmente el legislador traslada a la ciudadanía acerca de cómo resolver lo que no es otra cosa que la consecuencia del incumplimiento por el mismo de las obligaciones que la Constitución impone. Al margen de rigores jurídicos y en términos coloquiales, creo que dicho mensaje podría formularse del siguiente modo: «Dado que las cámaras parlamentarias (diputados y senadores) somos incapaces de cumplir adecuadamente con las obligaciones que la Constitución nos prescribe, cuando provoquemos retrasos en la renovación del Tribunal Constitucional, serán los magistrados constitucionales así nombrados los que se verán perjudicados y desvalorizado su estatuto constitucional pues el mandato se les verá reducido tanto como nosotros nos hayamos retrasado». La formula es evidentemente imaginativa. Pero la visión que las fuerzas políticas trasladan a los ciudadanos acerca de cómo abordar lo que formal y materialmente son incumplimientos de deberes constitucionales, me parece poco afortunada. 


\section{Francisco JaVier Díez Revorio}

Por las razones ya expuestas, la acumulación de la renovación de dos tercios del Tribunal en el mismo momento constituye una situación abiertamente inconstitucional, como lo es todo mandato que dure más de los nueve años constitucionalmente previstos. Cabría plantearse si en ciertos casos excepcionales esta regla puede sufrir matices, como los establecidos en el art. 16.4 LOTC para los supuestos en los que el mandato inicial haya durado menos de tres años. En realidad, esta situación es constitucional pues se trata propiamente de una excepción a la imposibilidad de renovación, que no es un criterio constitucional, sino legal.

Diferente es la previsión del nuevo artículo 16.5 que, con el muy notable propósito de impedir que en el futuro pueda volver a darse la indeseable situación de una nueva coincidencia en la renovación de dos tercios (o que en cualquier caso retrasos significativos alteren el ritmo constitucional de las renovaciones cada tres años), dispone en síntesis que a los magistrados que sean nombrados con retraso se les «descuente» el tiempo del retraso. A mi juicio, ello conlleva mandatos mucho más reducidos que, con carácter general, implicarían una inconstitucionalidad. Cuestión distinta es el supuesto, previsto en el mismo artículo, de quienes son nombrados para sustituir a un magistrado que ha cesado previamente generando una vacante anticipada (por ejemplo por fallecimiento o dimisión). En estos supuestos (que siempre darán lugar a mandatos menores de 9 años pero mayores de tres, pues de lo contrario se aplicaría el apartado anterior), aparte de su excepcionalidad y de la necesidad de cubrir estas vacantes sin alterar el criterio de la renovación por tercios, cabe argumentar que el mandato de nueve años es «compartido» por dos magistrados diferentes. Al fin y al cabo, en estas hipótesis de renuncia o fallecimiento anticipados, una interpretación estricta nos conduciría al callejón sin salida de no poder cumplir a la vez los criterios constitucionales de mandato de 9 años y de renovación por tercios.

Pero, como digo, no creo que esa solución excepcional sea generalizable a los supuestos de renovación con retraso. Por ello la solución introducida en el nuevo art. 16.5, aunque trata de evitar una situación indeseable e inconstitucional, introduce otra. Todo ello como consecuencia de que el legislador parece erróneamente haberse resignado a aceptar el hábito de los largos retrasos en la designación de los magistrados que corresponde proponer a las cámaras.

\section{AlFonso FernándeZ Miranda}

Ver las respuestas dadas a la pregunta número 3.

\section{VICENTE GIMENO SENDRA}

Aunque lamentable, no me parece inconstitucional la acumulación de tercios para la designación de candidatos, lo que sí creo inconstitucional es el último apartado del art. 16.5 Ley Orgánica del Tribunal Constitucional, introducido por la L.O. 8/2010, pues el art. 159.3 de la Constitución cifra su mandato en 9 años. 


\section{JAVIER PÉREZ Royo}

Sin duda es anticonstitucional la acumulación de las propuestas de nombramientos de más de un tercio, como lo es también la reforma de la LOTC mediante la LO 8/2010. La primera es una anticonstitucionalidad originaria y la segunda es una anticonstitucionalidad derivada. La primera se ha producido por el incumplimiento del plazo establecido en la Constitución para la renovación por el Senado de cuatro magistrados del Tribunal Constitucional, lo que ha conducido a que coincida dicha renovación con la que corresponde a los cuatro magistrados que ha de designar el Congreso de los Diputados. La LO 8/2010 se ha dictado para evitar que dicha anticonstitucionalidad se convierta en permanente. En el primer caso se incumple la Constitución por exceso. En el segundo por defecto. Se ha hecho de necesidad virtud y se ha procedido a una infracción por una vez de la Constitución, para evitar una infracción permanente. Aunque tal vez habría que decir que se ha procedido a una infracción que se espera que sea por una sola vez, ya que no hay seguridad de que el retraso en la designación de los magistrados por el Congreso de los Diputados no nos conduzca a una nueva acumulación de renovaciones.

\section{RAMÓN Punset BlanCO}

Lo que resulta inconstitucional, como he dicho, es la no renovación en plazo. Siendo semejante infracción tanto más grave cuanto mayor sea la demora, la acumulación temporal de renovaciones no es, en lo que respecta a una elección o designación simultáneas, contraria a la Constitución, ya que precisamente pone fin a una vulneración constitucional continuada.

En lo que concierne al nuevo apartado 5 del artículo 16 LOTC, introducido por la LO 8/2010, me parece acertado su primer inciso, que regula por remisión el procedimiento de elección y la duración del mandato de los Magistrados llamados a ocupar las vacantes producidas por causas distintas a la de la expiración natural del plazo de nombramiento, causas a las que se refiere pormenorizadamente el artículo 23 LOTC. El segundo inciso me parece igualmente correcto, ya que la definición del supuesto de hecho ( «Si hubiese retraso en la renovación por tercios de los Magistrados...») en modo alguno puede entenderse como una legitimación por el legislador de los retrasos inconstitucionales. En lo que atañe a la reducción del mandato en los supuestos considerados en ambos incisos, cierto es que el artículo 159.3 CE establece taxativamente que «los miembros del Tribunal Constitucional serán designados por un período de nueve años», pero ello no hace ilícita la disposición reductora del primer inciso del artículo $16.5 \mathrm{ni}$ las del artículo 23 de la LOTC, ya que ni el fallecimiento ni la renuncia, v.g., podrían conllevar el mandato completo del Magistrado que acceda por sustitución a la correspondiente vacante sin comprometer la eficacia de la renovación por tercios cada tres años, que impone igualmente el artículo 159.3 CE y que debe efectuarse por bloques, según la lectura más lógica del precepto constitucional (realizada además por el propio constituyente, que se refiere a «la misma procedencia electiva» en la Disposición Transitoria $9^{a}$ del texto constitucional). Este argumento también debe conducir a no objetar lo dispuesto en el segundo inciso del artículo 16.5 LOTC. 


\section{Juan Alfonso Santamaría Pastor}

\section{Sobre la posible inconstitucionalidad de la acumulación de renovaciones del Tribunal.}

Mi respuesta es negativa. El supuesto que se plantea no es, desde luego, deseable ni normal y, evidentemente, no se ajusta al régimen de renovación parcial que la Constitución establece; pero es un hecho, y los hechos no son ni pueden ser inconstitucionales; inconstitucionales sólo pueden serlo las conductas. Lo que quiere decirse, en suma, es que acumular, de facto, dos o más renovaciones en un solo trámite es algo desacorde con la Constitución; y que es también contrario a la misma la inactividad de las Cámaras o del Gobierno al no proceder en tiempo a los nombramientos; pero dicha inactividad carecería de sanción, como hemos dicho antes; y, de otra parte, de ella no podría deducirse que las designaciones que se hicieran (respecto del turno o turnos que no correspondan en ese momento) deban reputarse nulas.

Como estas conclusiones podrían parecer un artificio argumentativo, cabe añadir que, aunque la voluntad de la Constitución en el punto de la renovación del Tribunal por tercios es indudable, no me parece que su inobservancia, no deliberadamente querida, constituya una infracción grave y flagrante, digna de merecer reacciones tan enérgicas como la nulidad de los nombramientos. El precepto a que nos referimos persigue la finalidad secundaria de propiciar la continuidad doctrinal del Tribunal (sin perjuicio de lo que después se dirá a propósito de las renovaciones aisladas), lo que desde luego no forma parte del núcleo de la regulación que se hace de la justicia constitucional, cuyo modelo y funcionamiento no experimentarían variación alguna si la Constitución hubiera previsto, por ejemplo, la renovación en bloque cada nueve años. Y que esto es así lo acreditan, a mi juicio, dos circunstancias: primera, que sería perfectamente posible y legítimo una renovación múltiple provocada por circunstancias ajenas a la inactividad de los grupos políticos: por ejemplo, el fallecimiento simultáneo o la dimisión conjunta de diversos Magistrados. Y segunda, que propugnar la nulidad de los nombramientos acumulados llevaría al absurdo de una configuración definitiva del Tribunal con un número menor de Magistrados que el que la Constitución prevé (por lo menos, hasta que volviera a corresponder la renovación del mismo turno demorado).

Por supuesto, esta conclusión habría de matizarse en casos excepcionales. Es posible e imaginable la actuación torticera de un grupo político que, siendo minoritario, bloquea con su negativa una concreta renovación, contando con que sus perspectivas de mayoría absoluta para el siguiente proceso electoral le permitan ostentar una posición hegemónica en la fecha del siguiente turno de renovación, en el que podría designar una parte importante no ya de cuatro, sino de ocho Magistrados (obviamente, y dicho sin el menor asomo de ironía, no aludo a ningún supuesto concreto, que no se ha producido). Una maniobra de este porte sería abiertamente rechazable, por suponer un fraude constitucional notorio; pero, una vez más, nuestro ordenamiento carece de instrumentos formales de corrección de estas conductas, salvo un hipotético recurso de amparo, basado en la infracción del artículo 23, contra los nombramientos así efectuados (recurso que tendría que ser resuelto por un Tribunal de composición reducida o incluso mínima, lo que plantearía otras dificultades que no tiene sentido analizar aquí). 
2. Sobre la reforma del artículo 16.5 de la LOTC hecha por la Ley orgánica 8/2010, de 4 de noviembre.

El nuevo apartado 5 del artículo 16 de la LOTC, introducido por la Ley Orgánica 8/2010, contiene dos incisos de contenido muy dispar, que exigen una valoración separada.

a) Sobre la cobertura de vacantes producidas por causa ajena a la extinción del mandato.

Según este primer inciso, la renovación de estas vacantes habrá de producirse «con arreglo al mismo procedimiento utilizado para la designación del Magistrado que hubiese causado vacante y por el tiempo que a éste restase».

La preceptiva utilización del mismo procedimiento (esto es, elección por el Congreso, el Senado, el Gobierno o el Consejo General del Poder Judicial) no me parece adecuada a la Constitución: la renovación del Tribunal por tercios no sólo persigue, como antes se dijo, la continuidad en la doctrina de este órgano, sino también propiciar un sistema de posible reparto de los nombramientos entre mayoría y minorías parlamentarias (salvo en el caso de los efectuados por el Gobierno, que sería deseable se consensuaran con los grupos políticos). Una renovación aislada (de un solo Magistrado, por ejemplo) lleva en última instancia al nombramiento del candidato de la mayoría parlamentaria, con infracción del valor constitucional de pluralidad que inspira el artículo 159.3, o bien favorece las situaciones de bloqueo (al impedir el pacto de «el tuyo y el mío»).

Y no debe desdeñarse el inconveniente que supone el posible rechazo por parte del candidato o candidatos cuando su mandato vaya a ser muy inferior al plazo ordinario de nueve años, circunstancia que puede hacer mucho menos atractiva la oferta en no pocos casos. Es cierto que su nombramiento podría ser reiterado para un nuevo mandato, si éste fuera a ser de menos de tres años de duración (art. 16.4 de la LOTC); pero, con independencia de que su nuevo nombramiento será siempre incierto y dependerá de su comportamiento afín al partido de gobierno (con el natural deterioro de su imparcialidad), incluso un mandato de cuatro años puede resultar muy poco tentador.

No me parece, en cambio, que sea estimable el argumento formal de una hipotética inconstitucionalidad de la reducción del mandato, basado en que el artículo 159.3 de la Constitución prevé que los Magistrados sean nombrados por nueve años: este plazo debe ser entendido como aplicable en situaciones normales de cese y renovación, no en las anormales de cese anticipado o prórroga del mandato por demora en la renovación. Si se pretendiera observar literalmente el precepto constitucional, la inevitable producción de anomalías, acumuladas en el tiempo, haría imposible el correcto funcionamiento de renovación por turnos, que sólo afectaría a los Magistrados que hubieran agotado normalmente su mandato, pero no a los restantes; de manera que, en el momento de la renovación, el Congreso o el Senado, por ejemplo, podrían encontrarse en la situación de tener que nombrar sólo a un Magistrado, por ejemplo (cuando los otros tres no hubieran agotado su mandato de nueve años por haber sido nombrados con posterioridad al momento de su turno), con la consiguiente lesión al valor de pluralidad a que antes aludí.

Pero las soluciones sólo pueden ser desechadas cuando existan otras claramente preferibles; y, sencillamente, no soy capaz de imaginarlas. La única alternativa consistiría 
en posponer la renovación hasta el momento que corresponda a la del turno al que perteneciera el cesado (Congreso, Senado, Gobierno, CGPJ); pero ello dejaría al Tribunal disminuido en su composición durante años, alteraría fuertemente su funcionamiento interno (la composición de las Salas, como ya ha sucedido en la actualidad), supondría una mayor carga de trabajo para los restantes Magistrados y entrañaría el riesgo de que, hasta la renovación de su turno, se produjeran nuevas bajas; que no son, por desgracia, improbables.

A mi juicio, el balance de inconvenientes de las dos soluciones posibles se inclina ligeramente en contra de la primera, que, además, ofrece el problema de la afectación que produce al valor constitucional de pluralidad. Sin excesivo convencimiento, pues, optaría por la segunda.

b) El segundo inciso del nuevo artículo 16.5 de la LOTC no guarda otra conexión temática con el primero que la reducción del mandato de los Magistrados nombrados con posterioridad al momento en que la renovación debió producirse. Su finalidad es clara: homogeneizar el tiempo de desempeño de los cargos de cada uno de los turnos de nombramiento, de manera que la siguiente renovación podrá efectuarse por la totalidad de los cuatro Magistrados que lo integran.

La reducción del mandato que se establece me parece acertada. Podría ofrecer, desde luego, el inconveniente de que dicha reducción puede disminuir el interés por el nombramiento en los posibles candidatos; pero como no es probable — esperemos- que la demora en la renovación exceda de tres años, creo que un período de mandato de seis puede seguir siendo suficientemente atractivo.

7. ¿Sugeriría algunos modelos, de entre los que of rece el Derecho constitucional comparado occidental, para inspirar en España una revisión de la forma de abordar la cobertura de vacantes 0 la sustitución de los magistrados que tienen agotado el término de su mandato?

\section{Francisco Javier Díez Revorio}

Desde luego la prorrogatio está lejos de ser una solución universal a la situación que venimos comentando. Y aunque podría ser admisible en supuestos excepcionales, en España ha mostrado sus efectos claramente perversos y perniciosos cuando los retrasos muy prolongados en la renovación de los magistrados se convierten en la regla. Por ello es comprensible y razonable la búsqueda de otras soluciones, y en este sentido el Derecho Comparado europeo ofrece otras alternativas, como la de dejar vacantes las plazas de magistrados una vez concluido el mandato, hasta el momento de su renovación. Tal es el caso de Italia, donde como es sabido fue eliminada la prorrogatio de los magistrados.

Pero esta misma experiencia comparada pone de relieve que hay que ser conscientes de que ninguna solución está exenta de dudas, problemas y riesgos. En realidad, en mi opinión ninguna fórmula funcionará si no viene acompañada de una mayor responsabilidad de partidos políticos e instituciones a la hora de abordar las renovaciones del Tribunal, y en definitiva de un mayor respeto, tanto interno como externo, al Tribunal como institución. Como antes señalé, el Tribunal necesita cambios más profundos y por des- 
gracia menos inmediatos en sus efectos, que no siempre se pueden conseguir con modificaciones normativas.

En cualquier caso, y dada la situación a la que hemos llegado en España (el Congreso no solo no logra cumplir el mandato constitucional, sino que ignora el plazo dado por su propio presidente), cabe plantearse otras alternativas a la regulación legal actual. En este sentido, la doctrina tiende a apuntar diversas posibilidades para «sancionar» al órgano incumplidor en sus nombramientos, y así pueden leerse propuestas que van desde una disolución obligada del mismo (cuando es una Cámara parlamentaria, que es realmente el supuesto problemático) si no logra aprobar la propuesta, hasta «saltarlo» y que pierda esa opción de renovación en favor de otro órgano que señale la Constitución, o incluso dar, en esos casos de retraso, una facultad de propuesta al propio Tribunal, aunque fuese con carácter interino.

Como he dicho, no estoy seguro de que ninguna de estas fórmulas — que por lo demás requieren en muchos casos complejas reformas constitucionales- resolviera el problema, y todas ellas tienen inconvenientes, al crear situaciones excepcionales o interinas que tampoco creo que contribuyeran a mejorar la imagen del Tribunal. Reitero una vez más: cualquier retraso significativo en la renovación, sea cual sea la solución prevista, es una irregularidad y daña la imagen del Tribunal. Pero, llegados a este punto, quizá haya llegado el momento de considerar la eliminación de la prorrogatio, de modo que los magistrados cesasen automáticamente el día siguiente del cumplimiento de su mandato, aunque el Tribunal pudiera seguir funcionando mientras se cumplan los requisitos de quórum. Ciertamente, no puede ignorarse que esta forma de funcionamiento no dejaría de ser también algo anómala, aunque estuviese prevista en la ley. Pero creo que, visto lo visto, siempre sería menos mala que la solución actual. E igualmente pienso que con esa regulación las críticas en caso de no renovación y la responsabilidad política por la misma, caerían en la misma cámara parlamentaria, sin que hubiera de «compartirlas» el propio Tribunal.

Pero sobre todo, quiero pensar que, en tal caso, la hipótesis de un Tribunal con un tercio de vacantes serviría de acicate a los responsables políticos y a las cámaras para intentar cumplir siempre los plazos, generando una nueva práctica que se apartase de la que viene siendo últimamente habitual. Acaso una reforma en el sentido apuntado sea hoy la única manera de romper con la inercia del retraso y del incumplimiento.

\section{AlFonso Fernández Miranda}

Ya he expuesto en la respuesta anterior el modelo alemán, que me parece sumamente razonable y cuya eficacia está probada. Una incorporación de este modelo o de alguno similar, debidamente ajustados para garantizar su perfecta constitucionalidad, tendría, a mi juicio, algunos efectos positivos. Pero, entre nosotros, podría generar también algún riesgo.

Me parece que, en efecto, este sistema que emplaza al Parlamento y le obliga a elegir sin demora sus propios candidatos o a tener que hacerlo sobre la lista elaborada por el propio Tribunal, puede tener en España el mismo efecto de no tener que llegar ni a utilizarse, de suerte que las Cámaras, ante el riesgo de este emplazamiento, cum- 
plan espontáneamente los plazos. Pero el sistema sólo sirve para promover la renovación en tiempo y no sólo es inútil para el método de la selección de candidatos sino que, y éste es el riesgo, podría acelerar la tendencia al actual reparto por «cuotas de disposición unilateral». Quiero decir que, ante la necesidad de seleccionar de modo urgente y sin demora, podría incrementarse aún más la tendencia a que el consenso no recaiga sobre todos los seleccionados sino que el acuerdo se formalice después de que cada partido haya seleccionado unilateralmente los de su propio cupo. En suma, la prisa, en este caso, puede acabar invitando a la agudización de uno de los mayores problemas del sistema. En este sentido, entiendo que la importación del mecanismo debería ir acompañada de algún otro adicional (que no me resulta nada fácil de encontrar más allá de lo ya dicho en respuestas anteriores) que impida a los partidos elegir unilateralmente «a sus propios candidatos».

\section{VICENTE GIMENO SENDRA}

No conozco el Derecho comparado. Sin embargo, me atrevería a sugerir la necesidad de establecer, en el Tribunal Constitucional, un turno de Magistrados suplentes (integrados, por ej., por los Magistrados del Tribunal Supremo y/o los eméritos del propio Tribunal Constitucional) que, mediante un sistema de sorteo u otro objetivo, pudieran suplir a los titulares, en los supuestos de recusaciones o de indebida prórroga de sus funciones.

\section{JAVIER PÉREZ Royo}

Insisto en que no es un problema de ingeniería constitucional. O los dos grandes partidos españoles cogen el toro por los cuernos o iremos de crisis constitucional en crisis constitucional.

\section{RAMÓN Punset BlanCO}

Si se considera imposible rectificar la mala praxis de la renovación tardía de los Magistrados del TC - y hay que reconocer que hace mucho tiempo que los partidos mayoritarios, ayunos de las más mínimas virtudes republicanas, han agotado nuestra paciencia-, la solución no puede ser otra que la derogación del artículo 17.2 de la LOTC y la consiguiente eliminación de una prorogatio de simple creación legislativa, no impuesta por la Constitución, aunque tampoco contraria a ella. Se seguiría así la vía italiana, si bien en ese ordenamiento viene impuesta por el artículo 135 de la Constitución, tras la reforma introducida por la Ley constitucional de 22 de noviembre de 1967, n ${ }^{\circ}$, que reaccionaba de tal suerte frente a una disposición en sentido contrario de la propia Corte Constitucional. Establece dicho precepto que el juez constitucional, designado por nueve años a contar para cada uno desde el día en que presta juramento, «al final del mandato... cesa en el cargo y en el ejercicio de las funciones». 
¿Bastaría con esto para regularizar la elección de los Magistrados por las Cámaras o cabría pensar, como medida adicional, en una modificación del artículo 14 LOTC que, regresando al proyecto inicial de dicha Ley Orgánica, exigiera para la adopción de acuerdos por el Pleno la presencia de al menos ocho Magistrados?.

\section{Juan Alfonso Santamaría Pastor}

No tengo suficientes elementos de juicio para dar una opinión solvente sobre esta cuestión. Los sistemas de nombramiento de los miembros de los órganos de justicia constitucional son, bajo su apariencia formal, muy complejos, y se encuentran diseñados (y funcionan) en base a un conjunto de presupuestos implícitos de cultura política muy diferentes en cada país. Desconozco en profundidad tales presupuestos, por lo que creo preferible no improvisar ocurrencias.

$* * *$

Consideraciones globales de Manuel Jiménez De Parga, Ex Presidente del Tribunal Constitucional

El Tribunal Constitucional ha sufrido un desgaste notable. Esto es incuestionable. Como Presidente que fui de ese Tribunal me causa una gran pena lo que ha ocurrido y está ocurriendo. Raro es el día que no leo o escucho algo sobre el Tribunal Constitucional que me entristece. Dada mi condición de ex Presidente no quiero (ni debo, creo) contestar preguntas concretas. Sólo haré unas consideraciones globales.

Primera.-La clasificación de los magistrados en «conservadores» y «progresistas» es radicalmente arbitraria. Yo puedo dar testimonio de que en los nueve años que estuve en el Tribunal Constitucional algunos de los denominados «conservadores» fueron «progresistas» en sus decisiones, y lo mismo a la inversa.

Segunda.- No es cierto que quienes proponen el nombre de un futuro magistrado condicionan el comportamiento de éste en su actuación. Ha habido, y hay, magistrados libres y otros más o menos mediatizados. Así sucede en todos los tribunales del mundo.

Tercera.-A título personal he de recordar que yo fui propuesto por el gobierno de Felipe González, lo que hizo que alguno me tildara inmediatamente de despreciable «progresista», y luego, cuando me limité a interpretar la Constitución, según mi personal criterio, defendiendo las potestades del Estado frente a aspiraciones infundadas de ciertas Comunidades Autónomas, me pusieron el sambenito de «conservador» y con esta calificación dejé el Tribunal.

Cuarta._- A mi entender lo importante es que se elijan magistrados con conocimientos jurídicos acreditados, experiencia y un comportamiento cívico indiscutible. Si esta valoración se hace con seriedad, las sorpresas no saltarán, ni contra los que propongan ni contra los que esperan el resultado de la elección.

Quinta.-El Tribunal Constitucional ha realizado, durante años, una labor importante, muy valiosa. Las equivocaciones se registran en todos los tribunales del mundo. Por ejemplo, en el Tribunal Supremo de Estados Unidos fueron varios los errores de bulto - luego reconocidos y corregidos - y nadie pidió allí la supresión de ese tribunal. En 
el Tribunal Supremo español se han sostenido, a veces, tesis que luego nos causaron escándalo, y no por ello se solicita la eliminación del Tribunal Supremo. Sólo los que no tienen relación habitual con lo que dicen las sentencias y las otras resoluciones judiciales pueden pedir, en voz en grito, que se suprima el Tribunal Constitucional por los errores cometidos.

$* * *$

TITLE: Constitutional Court's renovation.

ABSTRACT: This academic survey, answered by Public Law Professors, focuses on the present situation of the Spanish Constitutional Court, and this Professors express their opinions about the composition of the Court, the new way on which its members are appointed by the Parliaments of the "Comunidades Autonomas», the requirements to be elected, the new rule relative to the "prorrogatio" in the term of office, and the delay in the election of the new members.

RESUMEN: Esta encuesta académica, a la que responden un grupo de Profesores de Derecho Constitucional, está dedicada a la renovación del Tribunal Constitucional y en ella se responde a preguntas relativas a su composición, el nuevo sistema de elección de magistrados en el que intervienen las Asambleas Legislativas de las CCAA, los requisitos de elegibilidad, la nueva norma sobre la "prorrogatio» de funciones y los retrasos en los nombramientos de nuevos magistrados.

KEY WORDS: Constitutional Court, composition of the Constitutional Court, election of the Constitutional Judges, requirements for the election, term of office.

Palabras Clave: Tribunal Constitucional, composición del Tribunal Constitucional, sistema de elección de los magistrados, requisitos de elegibilidad, duración del mandato. 